IZA DP No. 5085

New Century, Old Disparities:

Gender and Ethnic Wage Gaps in Latin America

Hugo Ñopo

Juan Pablo Atal

Natalia Winder

July 2010 


\title{
New Century, Old Disparities: Gender and Ethnic Wage Gaps in Latin America
}

\author{
Hugo Ñopo \\ Inter-American Development Bank \\ and IZA \\ Juan Pablo Atal \\ Inter-American Development Bank \\ Natalia Winder \\ Inter-American Development Bank
}

Discussion Paper No. 5085

July 2010

IZA

P.O. Box 7240

53072 Bonn

Germany

Phone: +49-228-3894-0

Fax: +49-228-3894-180

E-mail: iza@iza.org

\begin{abstract}
Any opinions expressed here are those of the author(s) and not those of IZA. Research published in this series may include views on policy, but the institute itself takes no institutional policy positions.

The Institute for the Study of Labor (IZA) in Bonn is a local and virtual international research center and a place of communication between science, politics and business. IZA is an independent nonprofit organization supported by Deutsche Post Foundation. The center is associated with the University of Bonn and offers a stimulating research environment through its international network, workshops and conferences, data service, project support, research visits and doctoral program. IZA engages in (i) original and internationally competitive research in all fields of labor economics, (ii) development of policy concepts, and (iii) dissemination of research results and concepts to the interested public.
\end{abstract}

IZA Discussion Papers often represent preliminary work and are circulated to encourage discussion. Citation of such a paper should account for its provisional character. A revised version may be available directly from the author. 
IZA Discussion Paper No. 5085

July 2010

\section{ABSTRACT New Century, Old Disparities:
Gender and Ethnic Wage Gaps in Latin America}

This paper surveys gender and ethnic wage gaps in 18 Latin American countries, decomposing differences using matching comparisons as a non-parametric alternative to the Blinder-Oaxaca (BO) decomposition. It is found that men earn 9-27 percent more than women, with high cross-country heterogeneity. The unexplained pay gap is higher among older, informal and self-employed workers and those in small firms. Ethnic wage differences are greater than gender differences, and educational attainment differentials play an important role in explaining the gap. Higher ethnic wage gaps are found among males, single-income generators of households and full-time workers, and in rural areas. An important share of the ethnic wage gap is due to the scarcity of minorities in high-paid positions.

JEL Classification: $\quad$ C14, D31, J16, O54

Keywords: $\quad$ gender, ethnicity, wage gaps, Latin America, matching

Corresponding author:

Hugo Ñopo

Inter-American Development Bank

Colombia Country Office

Carrera 7MA 71-21, Torre B, Piso 19

Bogota

Colombia

E-mail: hugon@iadb.org 


\section{Introduction}

Following a period of sustained economic growth at the end of the last century and the beginning of this century, Latin America still faces high inequality and lower well-being indicators among certain sectors of the population. Afro-descendants, indigenous peoples and women are often at the lowest economic percentiles of income distributions, facing barriers in access to sustainable income-generating opportunities (Paes de Barros et al., 2009).

Gender and ethnic gaps in wealth and income are only some of the outcomes of a series of other disparities that occur in different markets and within households. The most salient of these can be found in education, where not only attainment matters, but also quality. While there have been important advances towards gender parity on the former (Duryea et al., 2007), on the latter there is some evidence that differences have been increasing for recent cohorts (Calónico and Ñopo, 2007). Gender and ethnic differences also exist in labor market participation, unemployment and job turnover. These, voluntarily or involuntarily, reduce individuals' opportunities for on-the-job human capital accumulation. Last, but not least, intra-household arrangements are likely to be unfavorable to women. Budget-constrained parents can make only limited investment in their children's schooling, and household division of labor generally limits females' opportunities to participate in the labor force. All these disparities lead to differences in income generation capabilities, the outcome that has generated the largest share of analytical research.

This paper focuses on the final outcome, wages, providing both a comprehensive summary of the literature developed to date on gender and ethnic wage gaps in the region and a contemporary measure of those disparities. The measure presented in this paper is comparable across 18 Latin American countries and contains an improvement on the methodological limitations of the prevailing empirical approach.

After this introduction, Section 2 reviews the relevant literature. Section 3 presents the main results, starting with a description of the data sources, some basic statistics and a brief account of the empirical methodology and then provides the estimates of gender and ethnic wage gap decompositions. Section 4 summarizes the main findings and concludes. 


\section{The Literature on Gender and Ethnic Gaps}

Though with cross-country heterogeneity, the region has recently experienced a period of high growth in GDP rates, an expansion of labor force participation, and some increase in real wages in the formal sector (ILO, 2007). However, unemployment and underemployment rates remain high and the quality of jobs has diminished. An increasing share of workers are found to have no access to health and pension benefits, turnover rates have increased and temporary contracts have spread in the formal sector (Arias, Yamada and Tejerina, 2005). While there are mixed indications on whether gender and ethnic wage gaps are decreasing over time, there is general agreement that such gaps persist.

This section, dedicated to reviewing the empirical literature, with an emphasis on wage gaps, is divided into two parts: one devoted to the gender perspective and the other to the ethnic perspective (including studies that explore the interplay between gender and ethnic differentials). A comprehensive review of the whole literature produced for the region up to date on those topics is a daunting task. As a way of organizing the information, this section focuses on reviewing only those pieces of the literature providing a multi-country approach. Significant country-specific contributions to the literature have been summarized in the Annex (Table A3).

\subsection{Gender Wage Gaps: Beyond Human Capital Accumulation}

Since the mid-1980s, the region has seen a stable increase in female labor force participation, and women presently account for approximately 52 percent of the region's labor force. ${ }^{1}$ The evidence suggests that women's insertion into the labor market has been facilitated as a result of the region's economic growth, trade liberalization, rapid urbanization and changes in fertility patterns (Psacharopoulos and Tzannatos, 1992; Cox and Roberts, 1993). Such increase in female labor participation has been accompanied by a slow but steady rise in relative wages for nearly two decades, allowing women in most countries to contribute around one third of households' income (Duryea et al., 2004). However, in many countries in the region women are more likely to hold low-paid occupations (Márquez and Prada, 2007), and gender wage gaps, as this paper will show, remain substantial.

\footnotetext{
${ }^{1}$ Of these, around 10 percent are unemployed, almost 10 percent work in the agriculture sector, 14 percent in industry and 76 percent in the service sectors. The latter is significantly higher than in other regions of the world (ILO, 2007).
} 
While gaps in Latin America were smaller than in other regions of the world up to the late 1950s, the situation reversed from 1960 onwards (Frankema, 2008). The World Economic Forum currently ranks the region as the third most unequal (among nine) in economic participation and opportunity of women in relation to men (Hausmann, Tyson and Zahidi, 2008). ${ }^{2}$

Several authors have attempted to explain the sources of gender wage differentials in the region, exploring issues such as differences in individual characteristics and human capital endowments (see Table A3 in the Annex); regulation (Lim, 2002; Madrigal, 2004; Cruces and Galiani, 2007; Urdinola and Wodon, 2006) and occupational segregation (Deutsch et al., 2004; Tenjo, 2006), among others. The literature has also attempted to relate gender wage gaps to differences in income generating opportunities available in urban and rural areas, but no clear link can be found (Hertz et al., 2008).

In an analysis of 15 countries in the region with data for the end of the 1980s, Psacharopoulos and Tzannatos (1992) show that human capital accounts for one-third of the wage differential, leaving a large portion of wage gaps unexplained. However, by the middle of the current decade most Latin American countries had closed the education attainment gender gap (Duryea et al., 2007; Hausman, Tyson and Zahidi, 2008). Furthermore, Hertz et al. (2008) establish that women are presently found to have higher educational attainments than their male counterparts. Consequently, if educational attainment were equally rewarded in the labor market, women should be found to earn more than males.

Still, some empirical research has been able to provide interesting insights about the linkages between wage differentials and the differences in types of jobs men and women get. For instance, the sector-private or public - may influence the size of the differential. A review of 13 countries in Latin America finds that women are paid less than men in both sectors, but the private sector gap appears to be larger on average (Panizza and Qiang, 2005). In addition to private-public sorting, researchers have examined occupational segregation: the overrepresentation or underrepresentation of a group (women, men, youth, or ethnic groups) in a specific activity and its linkage with wage differentials in the region. Most studies agree that, in an effort to manage their housework and childcare responsibilities, women may permanently or

\footnotetext{
${ }^{2}$ This ranking is based on an index that encompasses other variables beyond wage disparities. The index also includes differences in labor participation and access to certain type of occupations as legislators, senior officials and managers and professional and technical workers. For more details, see Hausmann, Tyson and Zahidi (2008).
} 
temporarily withdraw from the labor market, choose occupations with flexible or relatively less working hours (Tenjo, 2006), or invest less in education or on-the-job training, thus diminishing their work experience (Terrell, 1992). As a result, women would be mostly concentrated in lowpaid jobs or face higher barriers when attempting to reach higher-level (better-paid) positions. Nevertheless, this may only explain part of the wage gap in the region. For instance, in Costa Rica, Ecuador and Uruguay, high and persistent levels of occupational segregation have been found to explain only a small portion of earnings differentials (Deutsch et al., 2004). Moreover, a comparative study between Brazil and Mexico showed that despite higher levels of gender occupational segregation in Mexico, gender wage gaps were wider in Brazil (Salas and Leite, 2007).

Currently, women have an important presence in the region's informal sector and some authors have argued that this fact may provide a potential explanation for wage disparities. A contributing fact to this argument has been that gender wage gaps are found to be larger in the informal sector than in the formal one. Plausible explanations include the small impact of education on wages in the informal sector, contrasting with the larger effect of experience, where for the most part, women have a disadvantage over men (Freije, 2009). Furthermore, looking closely at the region's self-employed, it seems that although there might be no real difference in self-employment rates among males and females, there are considerable gender differences in its quality, measured in terms of average earnings, conditions of work and income security (Barrientos, 2002).

Additional pieces of literature have discussed the role of regulation, such as maternity laws, gender quotas and employer child care as drivers for wage gaps. Created to protect and provide flexibility for women in certain occupations, labor legislation in areas such as maternity leave and pregnancy protection laws increase women's non-wage labor costs and therefore may be the cause of wage disparities. The empirical evidence in this regard, however, is not clear (Urdinola and Wodon, 2006). Other policies, such as access to affordable childcare, as well as programs to prevent domestic violence are found to be positively correlated with increases in both female labor force participation and earnings (Deutsch et al., 2004). The discussion has also stressed that differentials may correspond to women's roles in society which, regardless of their skill levels and/or potential, led them to choose careers in low productive sectors, and limited hours-low-skilled occupations (Tenjo, 2006; Contreras and Plaza, 2004). 


\subsection{Ethnic Wage Gaps: Access and Quality of Education}

Although gender wage gaps have been subject of a series of analytical work, the study of ethnic wage gaps has been somewhat constrained. Part of the explanation includes limited data availability, especially in household surveys and national censuses. Currently, only nine countries in Latin America include an "ethnic" question in their national censuses. ${ }^{3}$ Likewise, another important constraint is the significant number of individuals belonging to ethnic minorities who have not been registered and/or lack an identity document. Despite these constraints, important analytical efforts have been developed.

According to national statistics, there are approximately between 28 and 34 million indigenous persons in the region, representing roughly 10 percent of the population (Hall and Patrinos, 2006). In all countries, these groups are disproportionately represented among the poor and extreme poor, a situation which has not changed significantly over time. Moreover, since the 1990s, despite decreasing poverty rates in most countries in the region, the poverty among indigenous groups either reduced at a significantly slower pace, in comparison to the rest of the population, or increased, as in the case of Bolivia (Psacharopoulos and Patrinos, 1994; Jiménez et al., 2006).

On average, between 63 percent and 69 percent of the indigenous population are economically active, and they are overrepresented in the agriculture sector and among the selfemployed. Despite increasing levels of labor force participation over time, their salaries are in most countries, significantly lower than their non-indigenous peers. In the last decade this gap has been found to be narrowing, but also to remain significantly high for some countries such as Bolivia, Brazil, Guatemala and Chile (ILO, 2007).

Attempts to explain ethnic gaps have analyzed differences in human capital, especially education, but also differences in other individual characteristics such as age, migratory condition, and the interplay of ethnicity and gender. Despite improvements in educational achievements, indigenous groups are still found to earn significantly less than their nonindigenous counterparts (Psacharapoulos, 1992). Although indigenous peoples' low education indicators might explain to some degree the persistent ethnic wage differentials in some countries, in other countries only half of the wage gap is explained by productive characteristics (Patrinos, 2000). Authors have gone beyond educational attainment to explore other indicators

\footnotetext{
${ }^{3}$ These questions usually refer to mother tongue or self-ascription to an ethnic group.
} 
such as quality of education, measured in terms of certification of teachers, teacher/pupil ratio pertinence and materials (Rangel, 2004), as potential drivers of ethnic wage differentials in the region. Similarly, analysis has been carried out considering differences in returns by levels of education. Still, most of the pay differential remains unexplained (Hall and Patrinos, 2006).

Differences in sector of employment and in occupations between indigenous and nonindigenous groups have been identified as labor market barriers, as indigenous groups tend to be concentrated in low-paid sectors as well as in low-skilled and low-paid jobs (Rangel, 2004). One potential explanation could be given by the impact of social networks, which especially among migrants may have a significant influence on the economic sector, type and even quality of jobs obtained by indigenous workers. However, this factor is subject to a significant degree of heterogeneity among countries and between ethnic groups in a country (Fazio, 2007; Hall and Patrinos, 2006).

The impact of dominant language proficiency, as well as regional differences (urban/rural, north/south) are among the other potential issues discussed in the literature, mainly in country case studies (Chiswick, Patrinos and Hurst, 2000, and Contreras and Galván, 2003). There are still important issues that remain unexplored, such as the significant share of rural income represented by unsalaried labor. Also, further regional analysis is pending regarding indigenous peoples in urban areas, as well as their occupations, migratory patterns, sources of income and social capital dynamics.

For many topics the analysis has been constrained to country case studies, limiting their conclusions to a specific labor market and wage structure. However, most authors agree that, while additional research is needed to explain the so far "unexplained" portion of ethnic wages differential, human capital endowments are still a critical component. In other words, important progress could be made if interventions were concentrated in improving human capital accumulation among indigenous peoples, while exploring additional complementary policies to increase their return on investments in human capital (Hall and Patrinos, 2006).

The interplay of ethnicity and gender is of crucial importance, as one of the most recurrent stylized facts is that indigenous women appear to fare the worst in labor markets. Statistics in this area, however, are far from reliable, and enormous discrepancies exist among different sources. Indigenous women represent between 20 percent and 35 percent of the population in countries like Bolivia and Guatemala, and between 0.2 percent and 5 percent in 
Brazil, Ecuador and Panama. They represent, however, around 25-50 percent of the economically active population in some countries, not including those involved in unpaid work (Calla, 2007). Despite improvements in female labor force participation and earnings, indigenous women persistently remain at the bottom tier, showing the highest levels of poverty and exclusion (Piras, 2004). For instance, in spite of their important achievements in education and occupational attainment, Afro-Brazilian women continue to earn significantly less than men, both overall and within their own ethnic group (Lovell, 2000). Contreras and Galván (2003) also state that in Bolivia, being indigenous and female is considered the most unfavorable condition when entering the labor market and securing wages.

The paper next analyzes contemporary and comparable measures of gender and ethnic wage gaps in the region in an attempt to complement the existing literature with updated, comprehensive, and methodologically refined measures along both gender and ethnic dimensions.

\section{A Harmonized Measure of Wage Gap Decompositions for the Region}

This section presents non-parametric wage gap decompositions in order to assess the extent to which observed gender and ethnic wage gaps correspond to gaps in individuals' demographic and job related characteristics. The data sources are Household Surveys, circa 2005, of the 18 countries that make up the region: Argentina, Bolivia, Brazil, Chile, Colombia, Costa Rica, Dominican Republic, Ecuador, Guatemala, Honduras, Mexico, Nicaragua, Panama, Peru, Paraguay, El Salvador, Uruguay and Venezuela. ${ }^{4}$ Every data set is representative at the national level with the exception of Argentina and Uruguay for which have only urban representativeness. Each survey is being considered with its own sampling expansion factors such that, when expanded, each data set represents the working population of its country. The analysis that follows is focused on wage earners between 18 and 65 years old. Pooling all data sources leads to a single data set that is representative for most of Latin America's working population. ${ }^{5}$ Data on wages are obtained from the individuals’ primary occupation only, and hourly wages are

\footnotetext{
${ }^{4}$ The precise description of each data source with the exact year chosen for the analysis is shown in Table A1 of the Appendix.

${ }^{5}$ Also excluded from the data set all the observations for which hourly income or at least one of the characteristics used below as control variables was missing. Observations with outliers on hourly income are also excluded. Also, in the case of Guatemala, the data is restricted to people with full time jobs (i.e. working more than 35 hours a week).
} 
normalized to 2002 dollars using purchasing power parity (PPP) exchange rates and nominal GDP deflators.

As the gender variable is available in all national data sources, the gender wage gap analysis is performed for the whole sample of countries listed above. However, information on ethnicity is not as widespread and can be used for only seven of the 18 countries: Bolivia, Brazil, Chile, Ecuador, Guatemala, Paraguay and Peru. These countries represent almost 55 percent of the region's population. Along the ethnic dimension, individuals are classified as either minority or non-minority, depending on the specific ethnic groups that each survey considers. Ethnic “minorities” are defined by individuals’ self-assessment of being part of an indigenous group in Bolivia, Chile, Ecuador, Guatemala and Peru, by skin color in Brazil and by mother tongue in Paraguay. ${ }^{6}$ For this reason, cross-country comparisons of ethnic wage gaps should be used with caution. The details of this classification are presented in Table A2 of the Annex.

\subsection{Descriptive Statistics on Gender and Ethnic Disparities in Wages and Observable Demographic and Job Characteristics}

On average, men are found to earn 10 percent more than women in the region, while nonminorities earn a striking 37.8 percent more than minorities. These and other results are provided in Table 1, which provides average wages along the gender and ethnic dimension for the whole sample of workers between 18 and 65 years old reporting positive labor earnings. The first two columns are computed as multiples of the average females' wages, and the other two columns are computed as multiples of the average minorities' wages. Men earn more than women at any age, for each level of education, in any type of employment (self-employed, employers and employees) and in both large and small firms. Only females in rural areas are found to earn on average the same as their male counterparts. Wider disparities are found along the ethnic dimension, but the results are qualitatively similar except for the fact that ethnic wage gaps appear in both urban and rural areas.

\footnotetext{
${ }^{6}$ For simplicity, we use the term "minorities" to avoid confusion with most of the literature, but we recognize in some countries these ethnic groups represent majorities within their countries’ populations.
} 


\section{Table 1. Gender and Ethnic Relative Wages}

\begin{tabular}{|c|c|c|c|c|}
\hline & \multicolumn{2}{|c|}{ (Base: Average female wage $=100$ ) } & \multicolumn{2}{|c|}{$($ Base: Average minority wage $=100)$} \\
\hline & Male & Female & Non Minority & Minority \\
\hline All & 110.00 & 100.00 & 137.78 & 100.00 \\
\hline \multicolumn{5}{|l|}{ Age } \\
\hline 18 to 24 & 79.62 & 74.94 & 98.44 & 77.86 \\
\hline 25 to 34 & 106.57 & 100.90 & 133.62 & 98.18 \\
\hline 35 to 44 & 122.45 & 108.72 & 149.45 & 109.45 \\
\hline 45 to 54 & 127.15 & 111.30 & 159.80 & 113.49 \\
\hline 55 to 65 & 113.02 & 97.84 & 151.24 & 100.08 \\
\hline \multicolumn{5}{|l|}{ Education } \\
\hline None or Primary Incomplete & 73.06 & 71.08 & 108.72 & 74.67 \\
\hline Primary Complete or Secondary Incomplete & 95.27 & 75.98 & 113.36 & 90.79 \\
\hline Secondary Complete or Tertiary Incomplete & 141.67 & 118.10 & 155.67 & 127.12 \\
\hline Tertiary Complete & 201.99 & 178.94 & 223.68 & 160.16 \\
\hline \multicolumn{5}{|l|}{ Presence of children in the household } \\
\hline No & 117.03 & 105.04 & 144.65 & 104.40 \\
\hline Yes & 102.20 & 95.92 & 130.73 & 96.32 \\
\hline \multicolumn{5}{|l|}{ Presence of other member with labor income } \\
\hline No & 108.78 & 101.95 & 140.48 & 96.32 \\
\hline Yes & 110.81 & 99.40 & 136.67 & 101.90 \\
\hline \multicolumn{5}{|l|}{ Urban } \\
\hline No & 91.34 & 92.45 & 92.47 & 67.96 \\
\hline Yes & 116.76 & 101.60 & 145.73 & 108.13 \\
\hline \multicolumn{5}{|l|}{ Type of Employment } \\
\hline Employer & 195.34 & 180.11 & 264.33 & 215.35 \\
\hline Self - Employed & 95.94 & 88.81 & 134.96 & 95.12 \\
\hline Employee & 109.59 & 101.53 & 130.84 & 97.81 \\
\hline \multicolumn{5}{|l|}{ Part time } \\
\hline No & 105.04 & 92.22 & 133.00 & 94.31 \\
\hline Yes & 158.32 & 123.55 & 169.18 & 132.72 \\
\hline \multicolumn{5}{|l|}{ Formality } \\
\hline No & 95.81 & 86.82 & 113.45 & 83.90 \\
\hline Yes & 128.38 & 116.70 & 160.03 & 120.98 \\
\hline \multicolumn{5}{|l|}{ Small fim } \\
\hline No & 115.90 & 113.72 & 152.10 & 113.79 \\
\hline Yes & 85.28 & 78.13 & 122.92 & 87.60 \\
\hline \multicolumn{5}{|l|}{ Occupation } \\
\hline Professionals and technicians & 208.68 & 182.18 & 236.98 & 180.33 \\
\hline Directors and upper management & 212.50 & 176.66 & 271.72 & 210.97 \\
\hline Administrative personnel and intermediary level & 134.02 & 107.66 & 136.48 & 114.02 \\
\hline Merchants and sellers & 106.60 & 93.28 & 117.47 & 102.22 \\
\hline Service workers & 93.43 & 70.87 & 94.99 & 79.85 \\
\hline Agricultural workers and similar & 63.41 & 80.37 & 85.29 & 57.69 \\
\hline Non-agricultural blue-collars, drivers and similar & 95.59 & 70.41 & 126.07 & 102.14 \\
\hline Armed forces & 105.58 & 116.23 & 409.12 & 260.14 \\
\hline Occupations not classified above & 110.52 & 89.93 & 170.26 & 161.39 \\
\hline \multicolumn{5}{|l|}{ Economic Sector } \\
\hline Agriculture, Hunting, Forestry and Fishing & 59.13 & 54.03 & 87.64 & 58.31 \\
\hline Mining and Quarrying & 144.27 & 175.90 & 195.63 & 144.83 \\
\hline Manufacturing & 115.51 & 85.42 & 136.94 & 103.91 \\
\hline Electricity, Gas and Water supply & 153.89 & 165.60 & 178.43 & 151.34 \\
\hline Construction & 97.33 & 109.31 & 124.16 & 94.51 \\
\hline Wholesale and Retail, Trade and Hotels and Restaurants & 106.62 & 88.84 & 132.34 & 102.71 \\
\hline Transport, Storage & 115.73 & 125.02 & 158.21 & 129.27 \\
\hline Financing Insurance, Real Estate and Business Services & 150.50 & 149.12 & 196.78 & 143.38 \\
\hline Community, Social and Personal Services & 153.91 & 110.13 & 153.21 & 112.32 \\
\hline
\end{tabular}

Source: Authors' calculations using Household Surveys circa 2005. 
The wage disparities reported in Table 1 may reflect, to some extent, the differences in observable individuals' characteristics. These are shown in Table 2. As already pointed out by Hertz et al. (2008), working women in the region have achieved higher schooling than men. On the other hand, in relation to men women are underrepresented in managerial positions and overrepresented in other occupations like service workers, merchants, administrative personnel, and professionals. Noticeable economic sector differences also appear. Construction and agriculture are clearly male-dominated sectors while community, social and personal services is female dominated. Important gender differences are also present in working hours, as almost one-quarter of working women are part-time workers, compared to less than one-tenth of male workers. $^{7}$

Ethnic minorities display significantly lower educational attainment than non-minorities. As in the gender case, some disparities in type of employment and occupation appear along the ethnic dimension. On the other hand, ethnic differences in economic sectors are substantially smaller than along the gender divide. Also in contrast to the gender case, there are important ethnic differences in firm size: while almost half of non-minorities are employed in firms with five or less workers, almost three-quarters of minorities are employed in such firms.

\footnotetext{
${ }^{7}$ Part-time workers are considered those who work 30 hours or less per week at their main occupation.
} 
Table 2. Descriptive Statistics

\begin{tabular}{|c|c|c|c|c|}
\hline & Men & Women & $\begin{array}{c}\text { Non } \\
\text { Minority }\end{array}$ & Minority \\
\hline Age & 37.05 & 36.59 & 37.04 & 36.37 \\
\hline \multicolumn{5}{|l|}{ Education (\%) } \\
\hline None or Primary Incomplete & 20.90 & 15.89 & 14.93 & 24.82 \\
\hline Primary Complete or Secondary Incomplete & 44.51 & 37.60 & 38.65 & 42.99 \\
\hline Secondary Complete or Tertiary Incomplete & 29.08 & 37.96 & 38.39 & 27.61 \\
\hline Tertiary Complete & 5.51 & 8.56 & 8.04 & 4.59 \\
\hline Presence of children in the household (\%) & 47.41 & 55.26 & 49.34 & 54.49 \\
\hline Presence of other member with labor income (\%) & 60.18 & 76.41 & 70.81 & 65.96 \\
\hline Urban (\%) & 73.40 & 82.53 & 85.08 & 79.76 \\
\hline \multicolumn{5}{|l|}{ Type of Employment (\%) } \\
\hline Employer & 4.93 & 2.30 & 4.46 & 2.51 \\
\hline Self - Employed & 27.96 & 26.22 & 24.06 & 28.19 \\
\hline Employee & 67.11 & 71.49 & 71.48 & 69.30 \\
\hline Part time (\%) & 9.30 & 24.84 & 13.21 & 14.81 \\
\hline Formality (\%) & 43.56 & 44.11 & 52.23 & 43.42 \\
\hline Small fim (\%) & 52.39 & 54.22 & 49.23 & 70.08 \\
\hline \multicolumn{5}{|l|}{ Occupation (\%) } \\
\hline Professionals and technicians & 9.62 & 15.10 & 13.62 & 8.48 \\
\hline Directors and upper management & 3.32 & 2.76 & 4.75 & 2.27 \\
\hline Administrative personnel and intermediary level & 5.02 & 10.52 & 9.61 & 6.48 \\
\hline Merchants and sellers & 9.16 & 17.19 & 12.39 & 11.40 \\
\hline Service workers & 11.84 & 32.52 & 18.96 & 24.30 \\
\hline Agricultural workers and similar & 15.55 & 7.05 & 11.96 & 16.69 \\
\hline Non-agricultural blue-collars, drivers and similar & 32.04 & 9.41 & 27.59 & 29.00 \\
\hline Armed forces & 0.77 & 0.08 & 0.01 & 0.00 \\
\hline Occupations not classified above & 12.67 & 5.39 & 1.11 & 1.38 \\
\hline \multicolumn{5}{|l|}{ Economic Sector (\%) } \\
\hline Agriculture, Hunting, Forestry and Fishing & 18.07 & 3.78 & 12.21 & 16.92 \\
\hline Mining and Quarrying & 0.95 & 0.14 & 0.78 & 0.70 \\
\hline Manufacturing & 16.70 & 15.31 & 16.83 & 14.49 \\
\hline Electricity, Gas and Water supply & 0.85 & 0.22 & 0.64 & 0.50 \\
\hline Construction & 12.08 & 0.79 & 7.30 & 9.63 \\
\hline Wholesale and Retail, Trade and Hotels and Restaurants & 20.96 & 27.86 & 23.98 & 21.89 \\
\hline Transport, Storage & 8.97 & 1.94 & 6.56 & 5.35 \\
\hline Financing Insurance, Real Estate and Business Services & 3.10 & 3.10 & 3.72 & 1.70 \\
\hline Community, Social and Personal Services & 18.32 & 46.86 & 27.99 & 28.83 \\
\hline
\end{tabular}

Source: Authors' calculations using Household Surveys circa 2005. 
Having shown the differences in observable human capital and job characteristics, and their potential linkages to wage differentials, this section now formally assesses the role of these differences in wage gaps. The next sub-section briefly describes the methodological approach. Results for the gender wage gap analysis are then presented, followed by analysis of the ethnic dimension.

\subsection{Empirical Methodology}

In the same spirit of the Blinder-Oaxaca (BO) decomposition (Blinder, 1973; Oaxaca, 1973), the methodology used here attempts to explore the extent to which gender and ethnic wage gaps can be attributed to differences in observable characteristics. Even though the BO decomposition is the prevailing approach used in the empirical work on wage gaps, the literature has extensively documented its limitations and drawbacks. Three are particularly worth noting. First, the relationship between characteristics and wages is not necessarily linear, and recent data have been found to violate key implications of the Mincerian model, which is the key input of the BO decompositions (Hansen and Wahlberg, 1999, and Heckman, Lochner and Todd 2003). Second, $\mathrm{BO}$ is informative only about the average wage gap decomposition, providing no clues about the distribution of the differences in pay (Jenkins, 1994; DiNardo, Fortin and Lemieux, 1996; and Donald, Green and Paarsch, 2000). Third, BO fails to restrict its comparison to comparable individuals, which is likely to substantially upwardly bias the estimators for unexplained differences in pay (Barsky et al., 2002).

The econometric procedure pursued in this paper, introduced in Nopo (2009), is an extension of the BO decomposition using a non-parametric matching approach. In the case of gender gaps, all females and males are matched when showing exactly the same combination of observable characteristics. The matching characteristics are discrete, so the match is done perfectly and without using propensity scores or any notion of distance among the characteristics. After matching, the observations of working males and females are grouped into three sets: (i) one of males whose observable characteristics cannot be matched to those of any female in the sample, (ii) one of females whose observable characteristics cannot be matched to those of any male in the sample, and (iii) one of matched males and females, such that the distribution of observable characteristics for males is equal to that of females. 
The wage gap $\Delta$, computed as the difference in average wages between males and females and expressed as a percentage of females' average wage, is then decomposed into four additive elements:

$$
\Delta=\left(\Delta_{\mathrm{X}}+\Delta_{\mathrm{M}}+\Delta_{\mathrm{F}}\right)+\Delta_{0}
$$

As in the $\mathrm{BO}$ decomposition, one component of the gap, $\Delta_{X}$, is attributed to the differences in observable characteristics between males and females. However, as the matching procedure takes into account that not every combination of characteristics found among men is realized among women (and vice-versa), the computation of $\Delta_{X}$ is restricted to those males and females whose characteristics lie in the common support of both characteristics' distributions. Further extending the basic BO approach, instead of controlling for differences in average males' and females' characteristics, the matching procedure allows for controlling for differences in the distributions of those characteristics.

In turn, $\Delta_{M}$ is the portion of the wage gap that is due to the existence of males with combinations of characteristics that are not met by any women (for instance, highly educated young workers filling high-profile positions such as CEO). Analogously, $\Delta_{F}$ is the portion of the gap that is due to the existence of females with characteristics that cannot be matched to any male characteristics (as may be, for instance, old and low-skilled domestic workers). That is, $\Delta_{M}$ and $\Delta_{F}$ are two components of the wage gap that exist because the supports of the sets of observable characteristics of males and females do not completely overlap. The sum of the first three components, $\Delta_{X}+\Delta_{M}+\Delta_{F}$, is the portion of the gap that can be attributed to differences in observable characteristics.

Finally, $\Delta_{0}$ is the portion of the gap that cannot be explained by those characteristics and could be attributable to differences in unobservable characteristics, possibly including discrimination. As a result of the matching procedure, $\Delta_{0}$ is the wage gap that remains in the counterfactual situation in which males and females have the same distribution of observable characteristics but wage disparities persist. The reader is referred to Ñopo (2009) for technical details on the matching procedure, a comparison between it and the traditional approach based on linear regressions and proofs of the asymptotic consistency of the estimators derived from this method. The same procedure is used to decompose gender and ethnic wage gaps. 


\subsection{Gender Wage Gap Decompositions}

We first provide the decompositions that consider five possible sets of observable demographic characteristics as control variables (each shown in a column of Table 3). Each set results from sequentially adding a new characteristic to the previous one. The characteristics are added in an order that considers first those that are likely to be less endogenous to a model of wage determination.

The full set of demographic control variables, in the order included in the matching exercise, are the following: age, education, presence of children 12 years old or younger in the household (dummy), presence of other wage earner in the household (dummy) and urban area (dummy). Country of residence is another implicit control variable in each specification, as we only match individuals within the same country.

Table 3 shows the measure of the gender wage gaps, the four components comprising its decomposition (for five different sets of controls) and the percentages of males and females belonging to the common support of observable characteristics (that is, those who were matched).

Table 3. Gender Wage Gap Decompositions

\begin{tabular}{cccccc}
\hline & Age & + Education & $\begin{array}{c}\text { + Presence of children } \\
\text { in the } \mathrm{HH}\end{array}$ & $\begin{array}{c}\text { + Presence of other } \\
\text { income earner in the } \\
\text { HH }\end{array}$ & + Urban \\
\hline$\Delta$ & $10.00 \%$ & $10.00 \%$ & $10.00 \%$ & $10.00 \%$ & $10.00 \%$ \\
\hline$\Delta 0$ & $8.88 \%$ & $17.16 \%$ & $17.40 \%$ & $17.93 \%$ & $18.80 \%$ \\
$\Delta \mathrm{M}$ & $0.00 \%$ & $0.07 \%$ & $0.20 \%$ & $0.24 \%$ & $-0.28 \%$ \\
$\Delta \mathrm{F}$ & $0.00 \%$ & $-0.03 \%$ & $-0.11 \%$ & $-0.38 \%$ & $-0.58 \%$ \\
$\Delta \mathrm{X}$ & $1.11 \%$ & $-7.20 \%$ & $-7.49 \%$ & $-7.80 \%$ & $-7.94 \%$ \\
$\%$ Men in CS & $100.00 \%$ & $99.80 \%$ & $99.28 \%$ & $97.66 \%$ & $94.67 \%$ \\
$\%$ Women in CS & $100.00 \%$ & $99.94 \%$ & $99.78 \%$ & $99.12 \%$ & $97.90 \%$ \\
\hline
\end{tabular}

Source: Authors' calculations using Household Surveys circa 2005.

After controlling only for age, most of the gender wage gap remains unexplained (that is, most of $\Delta$ is captured by $\Delta_{0}$ ). Only 1 percentage point out of the 10 percentage points in the gender wage gap can be explained by the differences in age distributions between males and females in the labor markets. More prime-age workers are males rather than females and, on average, males are older than females in the labor markets (probably due to earlier retirement for females). 
After controlling for education, the unexplained component of the gender wage gap surpasses the original gap. That is, were males and females to have the same distribution of age and education in the labor markets, the gender gap would be even wider than its original level, jumping from 10 percent to 17 percent of average females' wages. This reflects higher educational achievement among female workers than among males, as noted in Table 1. Furthermore, the unexplained component of the wage gap is higher than the original gap after controlling for each subsequent set of controls, remaining practically constant after the addition of each subsequent characteristic. Education represents the most important demographic characteristic, suggesting that the gap would be even greater if males had the same educational attainment as females.

As mentioned above, the last two rows of Table 3 show the percentages of matched males and females for each set of characteristics (that is, those in the common support). The common support shrinks when the number of matching variables increases, as the likelihood of finding appropriate matches lessens. However, the common support is reasonably large even when controlling for the set of five characteristics and differences in the support of characteristic's distribution do not play a major role in explaining the wage gap. This can be confirmed by the small magnitude of both $\Delta_{M}$ and $\Delta_{F}$.

After controlling for observable individual demographic characteristics, we turn to the inclusion of job characteristics. The new variables considered are the following: type of employment (which could be self-employed, employer or employee); part-time work (a dummy variable taking the value 1 for those working 30 hours or less per week and 0 otherwise), and formality status (a dummy variable taking the value 1 for those covered by social security obtained from their labor relationship and 0 otherwise); economic sector (nine categories of ISIC rev. 2 classification system at the 1-digit level); occupation (nine categories of a slight modification of the ISCO classification system at the 1-digit level); and small firm (dummy equal to 1 if firm is no larger than 5 workers). ${ }^{8}$

As we do not have a strong a priori belief regarding which variable is "less endogenous" than the rest, and because of the strong correlation among some of them, we opted for the inclusion of these variables in a different way. The six job characteristics are added separately to

\footnotetext{
${ }^{8}$ In the Dominican Republic workers are considered formal if they report having a contract. Firm size is not used as a control variable in Brazil because it was not possible to construct the small firm variable for that country.
} 
the basic set of five socio-demographic matching variables reported in the last column of Table 3. In this way, we avoid drawing conclusions that are likely to depend on the order in which each variable is included. The results are provided in Table 4. For ease of comparison, the first column of Table 4 reproduces the last column of Table 3. In turn, the last column of Table 4 shows the decomposition that results from controlling for the whole set of observables considered: the five demographic and the six job-related characteristics.

Table 4. Gender Wage Decompositions

\begin{tabular}{ccccccccc}
\hline & $\begin{array}{c}\text { Demographic } \\
\text { Set }\end{array}$ & \& type of empl. & \& Part-time & \& Formality & \& Sector & \& Occupation & \& Small firm & Full Set \\
\hline$\Delta$ & $10.00 \%$ & $10.00 \%$ & $10.00 \%$ & $10.00 \%$ & $10.00 \%$ & $10.00 \%$ & $10.00 \%$ & $10.00 \%$ \\
\hline$\Delta 0$ & $18.80 \%$ & $17.23 \%$ & $27.30 \%$ & $17.99 \%$ & $23.59 \%$ & $16.84 \%$ & $18.83 \%$ & $19.47 \%$ \\
$\Delta \mathrm{M}$ & $-0.28 \%$ & $1.10 \%$ & $-0.29 \%$ & $-0.14 \%$ & $-5.02 \%$ & $-0.82 \%$ & $-0.19 \%$ & $-2.02 \%$ \\
$\Delta \mathrm{F}$ & $-0.58 \%$ & $-1.19 \%$ & $-2.03 \%$ & $-1.03 \%$ & $-0.33 \%$ & $-1.12 \%$ & $-0.88 \%$ & $-2.92 \%$ \\
$\Delta \mathrm{X}$ & $-7.94 \%$ & $-7.14 \%$ & $-14.98 \%$ & $-6.82 \%$ & $-8.25 \%$ & $-4.89 \%$ & $-7.75 \%$ & $-4.53 \%$ \\
\hline$\%$ Men in CS & $94.67 \%$ & $87.25 \%$ & $91.26 \%$ & $90.82 \%$ & $64.26 \%$ & $72.96 \%$ & $90.75 \%$ & $27.26 \%$ \\
$\%$ Women in CS & $97.90 \%$ & $95.12 \%$ & $93.46 \%$ & $96.36 \%$ & $87.96 \%$ & $86.79 \%$ & $96.28 \%$ & $44.71 \%$ \\
\hline
\end{tabular}

Source: Authors' calculations using Household Surveys circa 2005.

As can be seen in Table 4, none of the job characteristics is able to counter the jump in the unexplained gender wage gap after controlling for education. The unexplained component of the gap is considerably above the original gap after the addition of every job characteristic independently (and also when they are all added together). Also, the unexplained gap widens substantially after controlling for economic sector. The latter result suggests that gender segregation in economic sectors is not by itself the source of wage differentials. This is mainly driven by males' overrepresentation in agriculture, which is in turn the sector with the lowest average wages. The unexplained gap also widens substantially after controlling for part-time work, as women are overrepresented in part-time jobs which in turn are found to have an hourlywage premium over full time jobs.

The other four job-related characteristics (type of employment, formality, occupations and small firms) reduce the unexplained component of wage gaps with respect to the unexplained gap that exists after controlling for the five demographic characteristics, but only slightly. These findings challenge the popular belief that occupational segregation positively contributes to the gender wage gaps, reinforcing previous evidence on this matter (Barrientos, 2002). 
The last column of Table 4, which shows the decomposition exercise after controlling for the full set of observable characteristics, suggests that the unexplained gender wage gap in the region reaches 20 percent of average female wages. Indeed, the portion explained by the individual characteristics over the common support $\left(A_{x}\right)$ is negative, close to -5 percent. Even though the common support gets reduced after controlling for the full set of variables, the portion of the gap attributable to the non-common support is small (contrasting the results on ethnic wage differences that we will present below).

An advantage of the matching approach over the traditional regression-based decompositions is that it is informative not only about the average unexplained gap but also about its distribution. Exploiting this feature, it is possible to report gender wage gap decompositions country by country. Table 5 provides evidence of notable cross-country heterogeneity behind the region averages reported in Table 3. We provide measures of the original gap and the unexplained component after controlling for three different sets of matching variables: (i) age and education, (ii) the whole set of demographic matching variables and (iii) the whole set of demographic and job-related matching variables. 
Table 5. Original and Unexplained Components of the Gender Wage Gap, by Country

\begin{tabular}{|c|c|c|c|c|}
\hline \multirow[t]{2}{*}{ Country } & \multirow{2}{*}{$\begin{array}{c}\Delta \\
\%]\end{array}$} & \multicolumn{3}{|c|}{$\Delta 0$} \\
\hline & & $\begin{array}{c}\text { Age and } \\
\text { education [\%] }\end{array}$ & $\begin{array}{c}\text { + Presence of } \\
\text { children in the HH, } \\
\text { Presence of other } \\
\text { income earner in } \\
\text { the } \mathrm{HH} \text { and Urban } \\
\text { [\%] }\end{array}$ & $\begin{array}{l}\text { + Part-time, Formality, } \\
\text { Occupation, Economic } \\
\text { Sector, Type of } \\
\text { Employment and Small } \\
\text { Firm [\%] }\end{array}$ \\
\hline Argentina & 0.5 & $14.2 *$ & $12.6 *$ & $10.8^{*}$ \\
\hline Bolivia & -5.5 & -1.8 & 3.0 & 17.8 \\
\hline Brasil & 20.5 & $29.7 *$ & $31.4 *$ & $26.4 *$ \\
\hline Chile & 10.9 & $19.3 *$ & $18.6 *$ & $13.1 *$ \\
\hline Colombia & -0.9 & $7.1 *$ & $6.3 *$ & $7.3^{*}$ \\
\hline Costa Rica & -5.8 & $13.7^{*}$ & $13.6 *$ & $17.9^{*}$ \\
\hline Dominican Republic & -3.1 & $16.6 *$ & $17.3 *$ & $23.9 *$ \\
\hline Ecuador & -3.2 & $16.4 *$ & $13.6 *$ & 5.6 \\
\hline Guatemala & -3.3 & 0.3 & -0.7 & $17.7^{*}$ \\
\hline Honduras & 5.6 & $16.3 *$ & $16.3 *$ & $24.2 *$ \\
\hline Mexico & 2.6 & $7.8^{*}$ & $10.5 *$ & $15.3^{*}$ \\
\hline Nicaragua & 1.5 & $20.3 *$ & $19.3 *$ & $28.4 *$ \\
\hline Panama & -8.6 & $13.6 *$ & $16.2 *$ & $10.4+$ \\
\hline Peru & 18.3 & $19.4 *$ & $25.9 *$ & $23.5 *$ \\
\hline Paraguay & 6.2 & $16.0 *$ & $13.8 *$ & 6.9 \\
\hline El Salvador & 3.3 & $11.9 *$ & $16.0 *$ & $11.3 *$ \\
\hline Uruguay & 5.7 & $26.3 *$ & $27.5 *$ & $23.4 *$ \\
\hline Venezuela & 0.4 & $13.9 *$ & $13.8 *$ & $12.3 *$ \\
\hline Latin America & 10.0 & 17.2 & 18.8 & 19.5 \\
\hline
\end{tabular}

Source: Authors' calculations using Household Surveys circa 2005.

*Statistically different than zero at the $99 \%$ level

$\dagger$ Statistically different than zero at the 95\% level

In the first specification, $\Delta_{0}$ is statistically equal to zero in Guatemala and Bolivia, while it reaches 29.7 percent in Brazil. The influence of controlling by education varies significantly from country to country. While in Peru the unexplained component of the gap is almost equal to the original gap, reflecting small educational differences by gender, in Argentina the former is almost 30 times the latter. The gender differences in educational attainment for both countries differ substantially, especially at the extremes of the educational attainment distributions. At the lower extreme of educational distributions, while in Argentina the proportion of workers without education is almost zero for both men and women, in Peru the situation is unfavorable for females, as 7 percent of female workers but only 2 percent of male workers have no education. 
Among those with tertiary education, the gender gaps are wider in Argentina, where 40 percent of females and 25 percent of males are in that category, while in Peru the corresponding statistics are 29 percent for females and 24 percent for males.

Next, Figure 1 presents the four components of the wage gap by country (sorted by the magnitude of the unexplained component) for the specification with the richest set of control variables. Beyond the heterogeneity in the magnitudes of every component, interesting qualitative patterns arise. The portion of the gap attributable to differences in distributions of observable characteristics over the common support $\left(\Delta_{X}\right)$ is negative in every country, showing that in every country of the region women have combinations of characteristics (especially educational attainment) that are expected to have higher payoffs in labor markets than the characteristics of males.

Females' lower access to well-paid profiles or combinations of observable characteristics explains a substantial part of the wage gap in four countries: Nicaragua, Bolivia, Guatemala and Paraguay. On the other extreme, in seven other countries (Peru, Costa Rica, El Salvador, Argentina, Panama, Colombia and Ecuador) there are certain labor market profiles with labor earnings below the economies' averages and exclusive female presence. While for the first group of countries the evidence suggest that the problem of gender wage gaps is linked to one of females' barriers in access to high-paying occupations, for the second groups of countries the problem of wage gaps seems to be linked to females' confinement in low-paying segments of labor markets. 
Figure 1. Gender Wage Gaps Decompositions, by Country

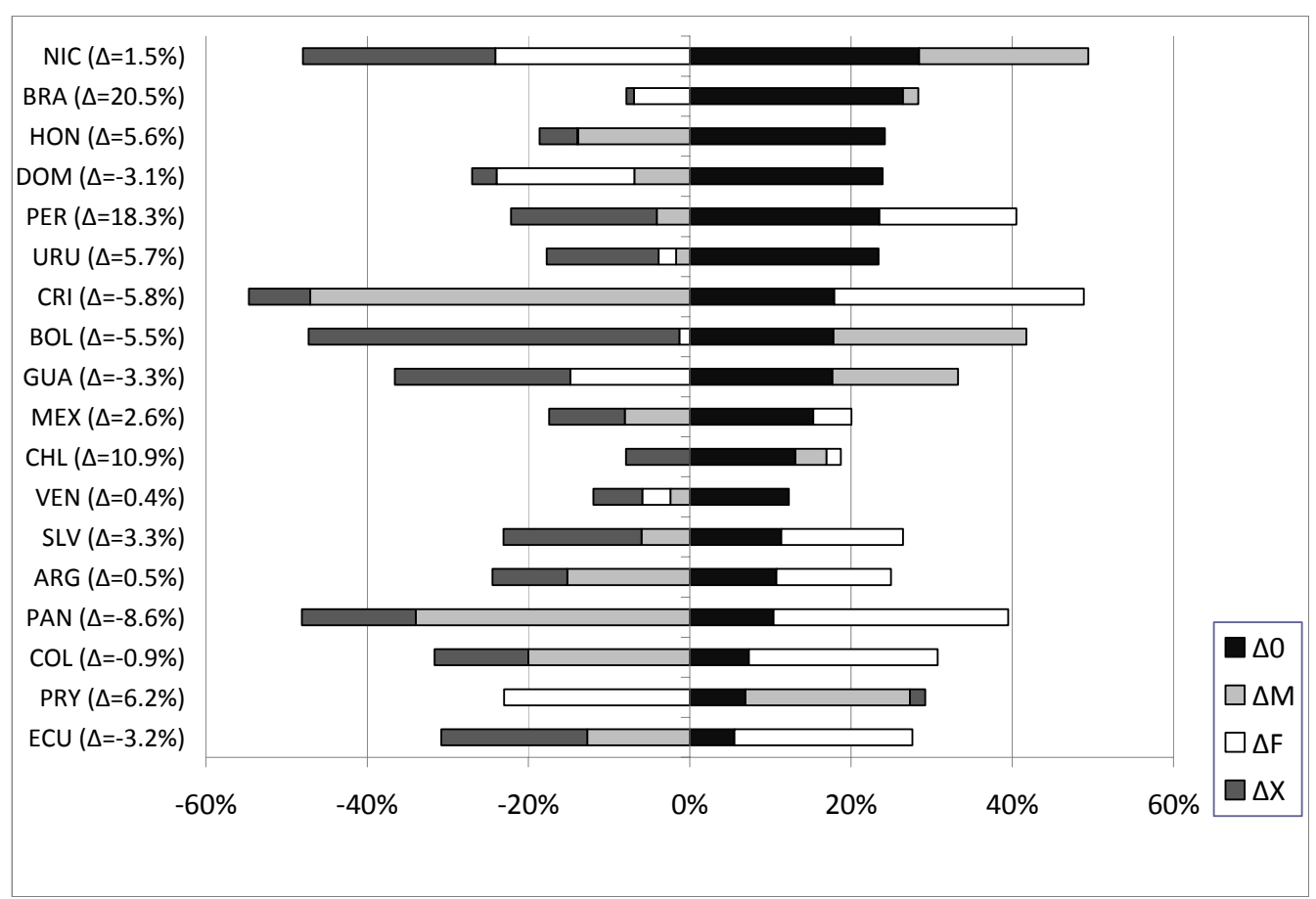

Source: Authors’ calculations using Household Surveys circa 2005.

Figure 2 provides further evidence of the heterogeneity of the decomposition results, showing confidence intervals for the unexplained component of the wage gaps, after controlling for all demographic and job-related characteristics, for different segments of labor markets. Richer information about the nature of the unexplained gender wage gaps arises, and the findings suggest a basis for explaining this problem and offering policy advice on how to address it.

The unexplained gender wage gap increases with age. Although one possible (and optimistic) interpretation of this result is that wage gaps are narrowing over time, such an assertion must be made with care. This finding could also be driven by unobservable characteristics correlated with age. For instance, this result may also be reflecting gender differences in labor experience, which could be exacerbated over time as women bear and raise children. Indeed, it is found that the unexplained component of the gender gap is slightly higher (although not statistically significant) among workers with children.

The unexplained gender wage gap is lower among those with tertiary education. One possible explanation is that more educated women fill positions in firms where there is less room for discretionary wage-setting or other discriminatory behavior. This hypothesis is supported by 
the fact that the unexplained wage gap is also found to be lower among formal workers and very high in small firms (where there is less presence of highly educated individuals).

The unexplained gender wage gap is higher among informal workers and those in small firms. These findings reinforce the idea that more highly educated females are able to find niches within the labor markets where there is less room for discriminatory behavior, while females with lower education are confined in segments where there is more room for discretionary wage-setting.

The unexplained gender wage gap is higher among the self-employed. This finding challenges the view that explains the existence of gender wage gaps as a result of employers' discrimination. Nonetheless, this still leaves room for an explanation of wage gaps on the basis of customers' discrimination (which we can neither assert nor deny at this point). Linked to this result, the unexplained gender wage gap is also highly dispersed among employers, reflecting possible heterogeneities in entrepreneurial abilities and success.

The unexplained gender wage gap for part-time workers is on average similar to that one of full-time workers, but more disperse. The descriptive statistics show that in Latin America part-time workers earn more than their full-time counterparts and also that part-time work is prevalent among females. However, these circumstances are not reflected in a higher wage premium for females. The higher dispersion of unexplained gender wage gaps among those working part-time may be a reflection of the different constraints and motivations that females face when deciding on such a form of labor supply.

The unexplained gender wage gap is negative in the mining sector and in the armed forces. These are, however, particular occupations and economic sectors traditionally regarded as male-dominated. As a matter of fact, while 0.77 percent of males are employed in the armed forces, only 0.08 percent of females are. Likewise, 0.95 percent of males work in mining industries, compared to only 0.14 percent of females. The few females who obtain a job in those male-dominated environments enjoy a considerable premium and on average earn more than their male counterparts. Presumably, selection plays an important role here or the jobs that women perform in these sectors differ substantially from those than men perform. 
Figure 2. Confidence Intervals for the Unexplained Gender Wage Gap (after Controlling for Demographic and Job-Related Characteristics) by Different Characteristics
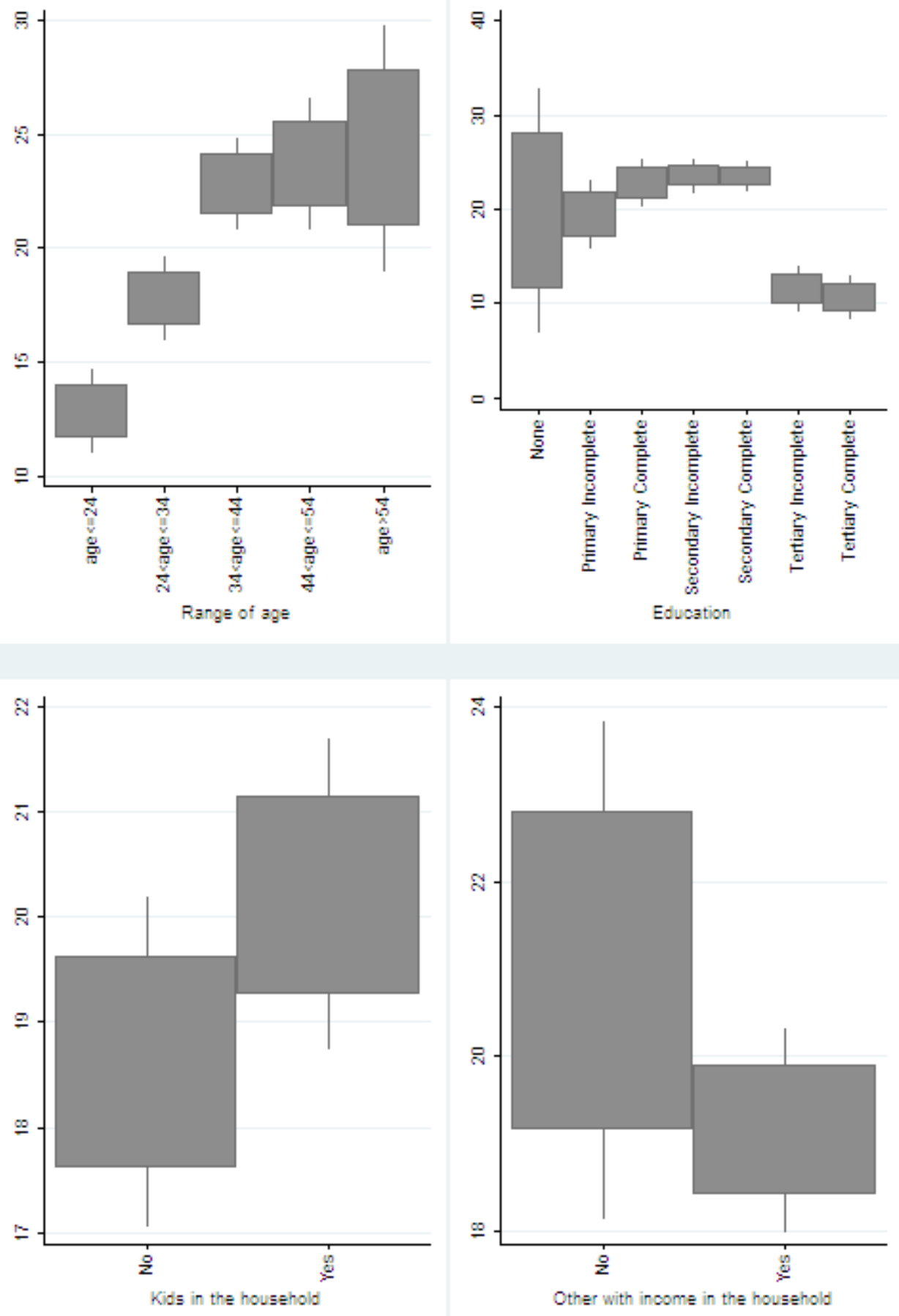

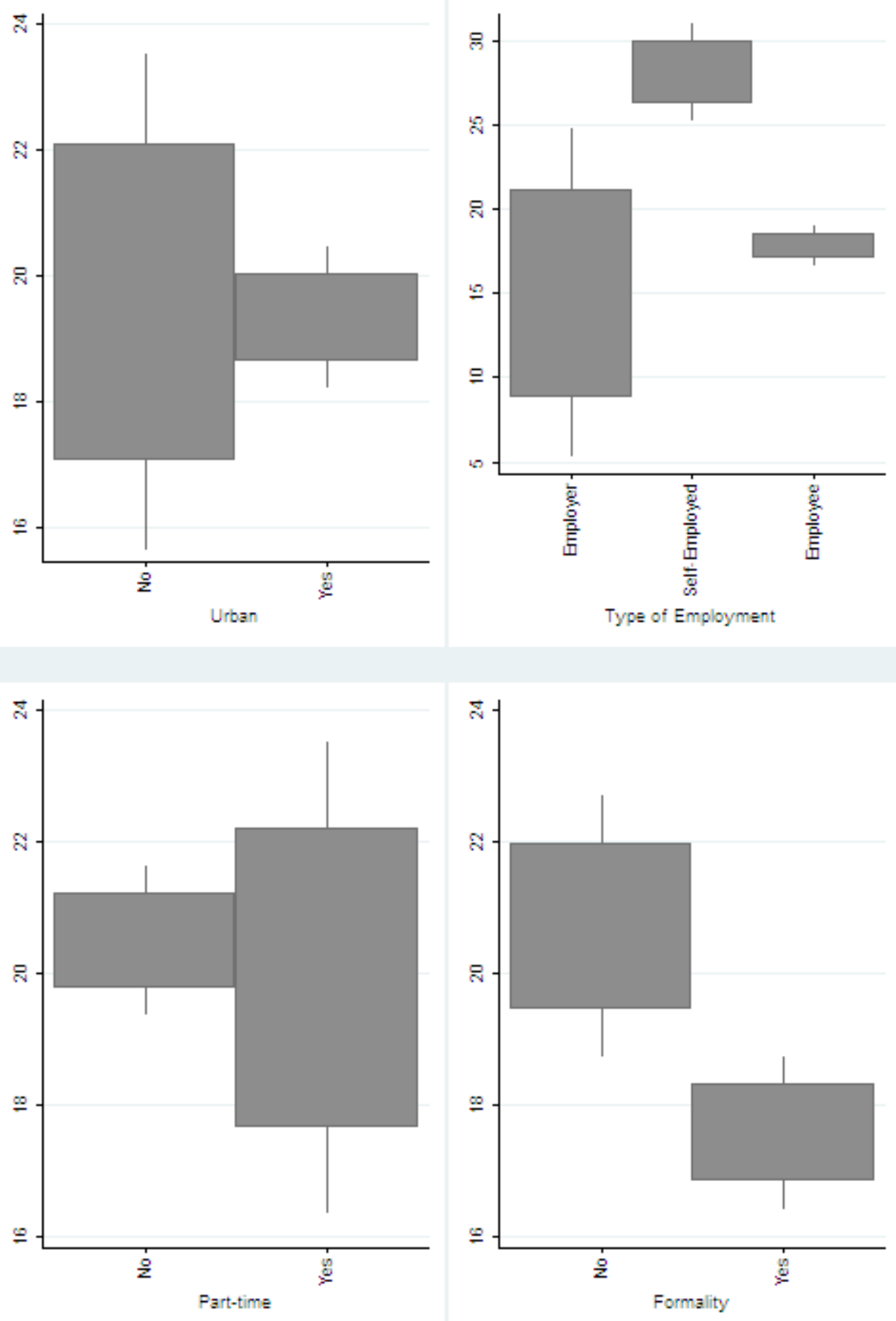

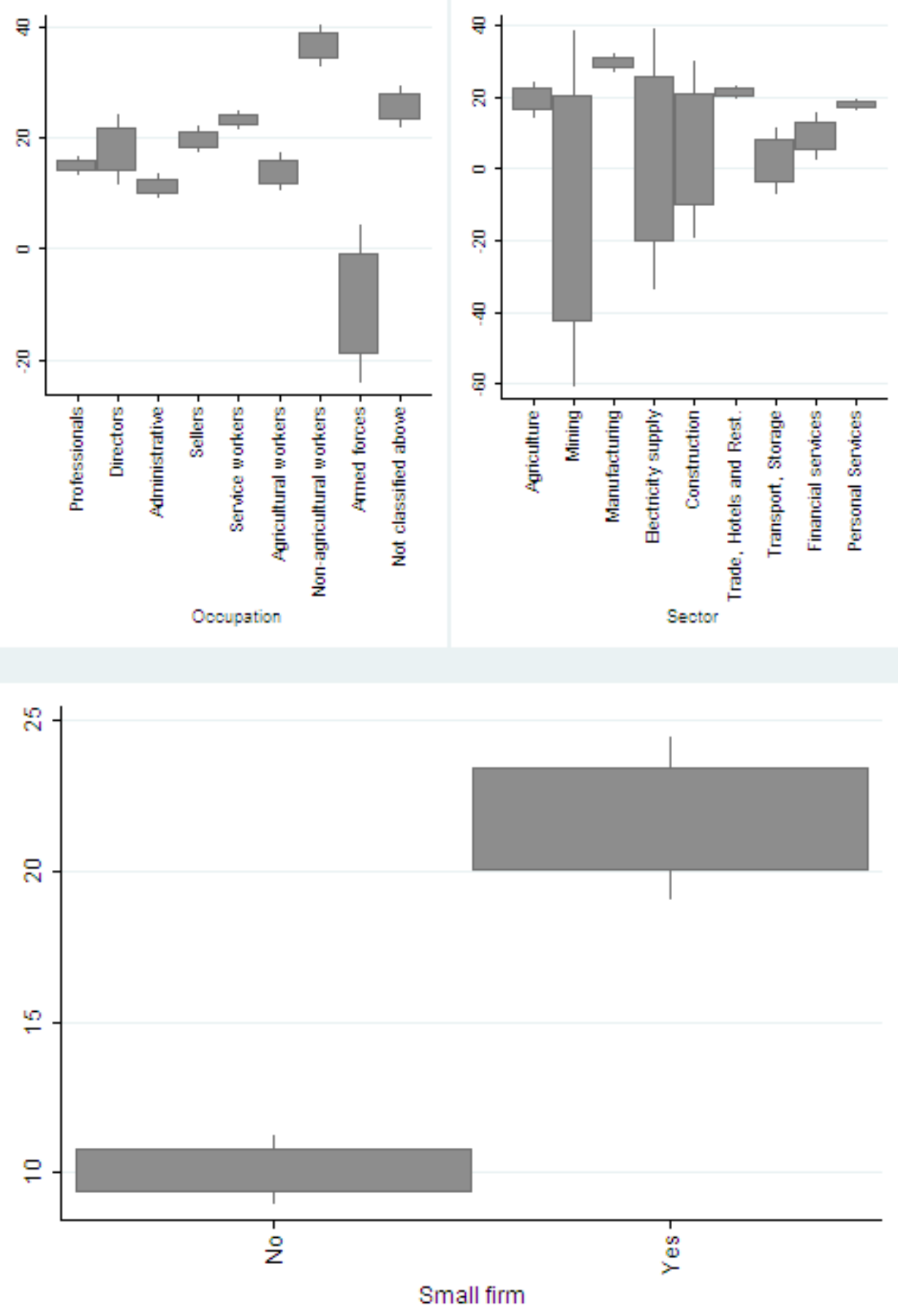

Source: Authors' calculations using Household Surveys circa 2005.

Note: The extremes of the boxes correspond to $90 \%$ confidence intervals for unexplained wages and the extremes of the whiskers to $99 \%$ confidence intervals. 
Next, Figure 3 presents a different exploration of the distribution of gender differences in pay. It shows the magnitude of unexplained wage gaps along percentiles of the earnings distribution. For that purpose, we compute the wage gap between the representative male and female at each percentile of the distributions of earnings of males and females, respectively. We do this using the matching samples, so the wage differences are those that remain unexplained after controlling for observable characteristics. We report the results after matching with four different sets of control variables. The wage gap at each percentile is expressed as a percentage of the wage of the representative female in the corresponding percentile.

The results depicted in Figure 3 show higher unexplained wage gaps at the lower end of the earnings distribution, followed by a sharp decrease after the $6^{\text {th }}$ percentile, a somewhat flat or slightly increasing pattern in the middle and a negative slope in the upper tail of the distribution (after the $80^{\text {th }}$ percentile). The introduction of education as a matching variable, as shown before, moves up the unexplained gender wage gap, but in this figure it is shown that education does not move the gap homogeneously along the overall distribution. Then, the introduction of presence of children and other income earners in the household (to achieve the "Demographic Set" of matching characteristics) leaves almost unchanged the magnitude of the unexplained gender wage gaps for percentiles 40 and above but increases the magnitude of it by almost 10 percentage points for the lower percentiles (between 5 and 15). Finally, the introduction of the set of job-related characteristics (to achieve the "Full Set" of matching characteristics) moves the unexplained component of the gender gap in different ways. This component increases among the lowest-earning individuals (percentiles 1 to 5), decreases among lower-earning individuals (percentiles 6 to 35) and increases for those in the upper end of the distribution (percentiles 65 and above). This suggests important differences in the way gender segmentation occurs in the labor markets and the impacts of gender segmentation on labor earnings. 


\section{Figure 3. Unexplained Gender Wage Gap by Percentiles of the Wage Distribution of Males and Females}

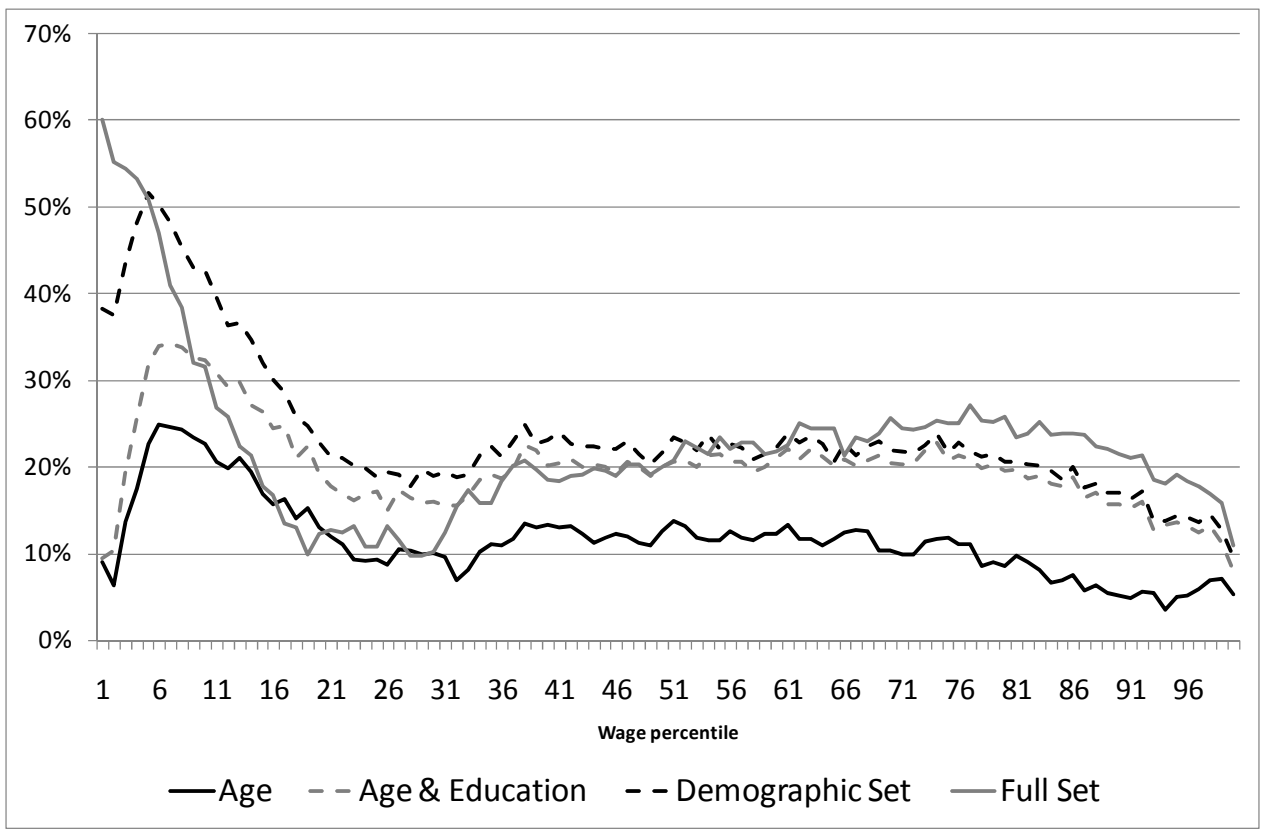

Source: Author’s Calculations using Household Surveys circa 2005.

\subsection{Ethnic Wage Gap Decompositions}

Following the same strategy developed previously for gender, this subsection turns to the analysis of ethnic wage gaps. Before the results are described it is necessary to perform a homogenizing exercise. As mentioned above, the ethnic classification is available only for a restricted subset of seven countries (Bolivia, Brazil, Chile, Ecuador, Guatemala, Paraguay and Peru). Hence, in order to make the ethnic wage gap decompositions comparable to those reported along the gender dimension, it is necessary to provide first an assessment of the gender wage gap decompositions using only those seven countries. This exercise also adds the ethnicity dummy (distinguishing minorities vs. non-minorities) to the sequence of control variables of Table 3. Results are provided in Table 6. 
Table 6. Gender Wage Gap Decompositions

\begin{tabular}{|c|c|c|c|c|c|c|}
\hline & Ethnicity & + Age & + Education & $\begin{array}{c}\text { + Presence of } \\
\text { children in the } \mathrm{HH}\end{array}$ & $\begin{array}{c}\text { + Presence of other } \\
\text { income earner in the } \\
\mathrm{HH}\end{array}$ & + Urban \\
\hline$\Delta$ & $15.65 \%$ & $15.65 \%$ & $15.65 \%$ & $15.65 \%$ & $15.65 \%$ & $15.65 \%$ \\
\hline$\Delta 0$ & $17.16 \%$ & $16.87 \%$ & $24.50 \%$ & $24.40 \%$ & $24.87 \%$ & $26.54 \%$ \\
\hline$\Delta \mathrm{M}$ & $0.00 \%$ & $0.00 \%$ & $0.27 \%$ & $0.60 \%$ & $0.75 \%$ & $-1.08 \%$ \\
\hline$\Delta \mathrm{F}$ & $0.00 \%$ & $0.00 \%$ & $-0.10 \%$ & $-0.34 \%$ & $-0.84 \%$ & $-0.95 \%$ \\
\hline$\Delta \mathrm{X}$ & $-1.51 \%$ & $-1.22 \%$ & $-9.03 \%$ & $-9.01 \%$ & $-9.13 \%$ & $-8.86 \%$ \\
\hline \% Men in CS & $100.00 \%$ & $100.00 \%$ & $99.32 \%$ & $98.29 \%$ & $95.52 \%$ & $90.30 \%$ \\
\hline \% Women in CS & $100.00 \%$ & $100.00 \%$ & $99.77 \%$ & $99.33 \%$ & $98.43 \%$ & $96.86 \%$ \\
\hline
\end{tabular}

Source: Authors' calculations using Household Surveys circa 2005.

As shown in Table 6, this subsample of countries displays higher gender wage gaps than the region as a whole (15.65 percent compared to the 10 percent reported in Table 3 ). This is mostly due to the higher gender wage gaps that exist in Brazil, Peru and Paraguay, together with the higher share that these countries represent within the sample of the seven countries with ethnic data. Note that controlling for ethnicity alone does not provide much explanation for gender gaps. The results are qualitatively similar to those reported in Table 3, with a notorious jump in the unexplained component of the gap after adding education as a matching variable.

Next, Table 7 shows the ethnic gap decompositions for the same seven countries. The set of matching variables and the sequence in which these variables are added follows the same pattern as in the gender decompositions.

Table 7. Ethnic Wage Gap Decompositions

\begin{tabular}{|c|c|c|c|c|c|c|}
\hline & Gender & + Age & + Education & $\begin{array}{c}\text { + Presence of } \\
\text { children in the } \mathrm{HH}\end{array}$ & $\begin{array}{c}\text { + Presence of other } \\
\text { income earner in } \\
\text { the } \mathrm{HH}\end{array}$ & + Urban \\
\hline$\Delta$ & $37.78 \%$ & $37.78 \%$ & $37.78 \%$ & $37.78 \%$ & $37.78 \%$ & $37.78 \%$ \\
\hline$\Delta 0$ & $39.96 \%$ & $39.50 \%$ & $27.90 \%$ & $26.90 \%$ & $26.19 \%$ & $25.11 \%$ \\
\hline$\Delta \mathrm{W}$ & $0.00 \%$ & $0.01 \%$ & $1.38 \%$ & $2.37 \%$ & $3.55 \%$ & $3.54 \%$ \\
\hline$\Delta \mathrm{l}$ & $0.00 \%$ & $0.00 \%$ & $-0.17 \%$ & $-0.41 \%$ & $-0.80 \%$ & $-0.63 \%$ \\
\hline$\Delta \mathrm{X}$ & $-2.18 \%$ & $-1.72 \%$ & $8.67 \%$ & $8.92 \%$ & $8.84 \%$ & $9.75 \%$ \\
\hline$\%$ Non Minority in CS & $100.00 \%$ & $100.00 \%$ & $97.96 \%$ & $95.94 \%$ & $93.28 \%$ & $89.61 \%$ \\
\hline \% Minority in CS & $100.00 \%$ & $100.00 \%$ & $99.73 \%$ & $99.26 \%$ & $98.14 \%$ & $95.73 \%$ \\
\hline
\end{tabular}

Source: Authors' calculations using Household Surveys circa 2005.

The total ethnic wage gap (37.78 percent) is considerably higher than the gender wage gap (15.65 percent for this set of countries). This is also true for the unexplained components of the wage gap after controlling for gender and age. However, once education is added to the matching variables the unexplained component of the ethnic gap decreases significantly, while the opposite occurred in the gender gap analysis. As noted in Table 2 above, ethnic minorities 
have considerably lower educational attainment than non-minorities, which explains the big drop in the unexplained component after that variable is added (from 40 percent of average minorities' wages to 28 percent). Still, a considerable portion of the gap remains unexplained, suggesting that, besides their lower access to education, ethnic minorities have lower returns to schooling than non-minority individuals. ${ }^{9}$ After education, the other demographic variables (presence of children and other income earners in the household) do not add much to the explanation of ethnic wage gaps.

As in the case of the gender gap analysis, job-related characteristics are added as matching variables after the full set of demographics. Table 8 presents the results of the decompositions obtained from adding each of the six job-related characteristic at once. To facilitate the comparison of results, the first column of Table 8 reports again the last column of Table 7, which results after matching on the six demographic characteristics. As was also done in the gender analysis, the last column of Table 8 shows the wage gap decompositions resulting from matching on the full set of variables (the six demographic characteristics and the six jobrelated characteristics).

Table 8. Ethnic Wage Gaps Decompositions

\begin{tabular}{|c|c|c|c|c|c|c|c|c|}
\hline & $\begin{array}{c}\text { Demographic } \\
\text { Set } \\
\end{array}$ & $\&$ type of empl. & \& Part-time & \& Formality & \& Sector & \& Occupation & \& Small firm & Full Set \\
\hline$\Delta$ & $37.78 \%$ & $37.78 \%$ & $37.78 \%$ & $37.78 \%$ & $37.78 \%$ & $37.78 \%$ & $37.78 \%$ & $37.78 \%$ \\
\hline$\Delta 0$ & $25.11 \%$ & $22.67 \%$ & $25.87 \%$ & $22.36 \%$ & $22.76 \%$ & $18.02 \%$ & $25.12 \%$ & $12.88 \%$ \\
\hline$\Delta \mathrm{W}$ & $3.54 \%$ & $6.54 \%$ & $4.66 \%$ & $4.88 \%$ & $6.07 \%$ & $7.17 \%$ & $4.04 \%$ & $21.23 \%$ \\
\hline$\Delta \mathrm{l}$ & $-0.63 \%$ & $-1.39 \%$ & $-1.36 \%$ & $-0.82 \%$ & $-1.14 \%$ & $-0.96 \%$ & $-1.10 \%$ & $-7.27 \%$ \\
\hline$\Delta \mathrm{X}$ & $9.75 \%$ & $9.96 \%$ & $8.61 \%$ & $11.36 \%$ & $10.09 \%$ & $13.55 \%$ & $9.73 \%$ & $10.94 \%$ \\
\hline$\%$ Non Minority in CS & $89.61 \%$ & $83.51 \%$ & $85.91 \%$ & $84.81 \%$ & $73.23 \%$ & $74.77 \%$ & $84.99 \%$ & $42.98 \%$ \\
\hline \% Minority in CS & $95.73 \%$ & $91.23 \%$ & $92.29 \%$ & $93.13 \%$ & $83.57 \%$ & $85.03 \%$ & $94.38 \%$ & $51.39 \%$ \\
\hline
\end{tabular}

Source: Authors' calculations using Household Surveys circa 2005.

The comparison of the six job-related characteristics reveals that, in contrast with the gender case, occupational segregation plays an important role in explaining ethnic wage gaps. In fact, occupation is the characteristic that most reduces the wage gap. When this characteristic is added to the demographic set of matching variables the unexplained component decreases from 25 percent to 18 percent. Of the other five job-related covariates, three positively contribute to the ethnic wage gaps but with small effects (2-3 percentage points): type of employment,

\footnotetext{
${ }^{9}$ There also could be the case that lower returns to schooling may actually generate incentives to ethnic minorities to drop out of the educational system or to exert less effort while in school.
} 
formality and economic sector. The other two (part-time and small firm) have almost no effect on ethnic wage gaps.

However, when all these covariates are considered together (last column of Table 8), the unexplained component of the ethnic wage gap diminishes substantially. Interestingly, when the full set of matching variables are considered, only a third of the ethnic gap remains unexplained. Ethnic gaps are notable, but most of them can be explained by observable productive characteristics. Almost one-fourth of the gap can be explained by differences in the distribution of characteristics over the common support $\left(\Delta_{X}\right)$ and an important share of the gap can be explained by the component that exists because non-minorities reach certain combinations of human capital characteristics that minorities fail to reach $\left(\Delta_{W}\right)$. Indeed, more than half of the ethnic wage gap is attributable to the existence of these sorts of access barriers to high-paying segments of the labor markets.

Not surprisingly, when the full set of demographic and job-related matching characteristics is used, only 43 percent of non-minorities and 51 percent of minorities lie on the common support of distributions of observable characteristics. An even higher segmentation of labor market was reported along the gender divide, but with no substantial contribution to the wage gaps as in the ethnic case. Further analysis of the combinations of characteristics found among non-minorities but not among minorities promises to increase our understanding of ethnic wage gaps. Table 9 provides descriptive statistics of the sample of non-minorities divided by whether they are on the common support (that is, they have observable characteristics comparable to those of minorities). The most salient differences between the two groups are that unmatched non-minorities are, in comparison to matched non-minorities, older, more educated, employed in a professional, director or upper management position, more likely to be employers and more likely to work part-time. In comparison to matched non-minorities (in the common support), they are less likely to have other income earners at home, to work in the formal sector, and to be service workers. 
Table 9. Descriptive Statistics for Non-Minorities in and out of the Common Support after Matching on the Full Set of Demographic and Job-Related Characteristics

\begin{tabular}{|c|c|c|}
\hline & $\begin{array}{c}\text { Out of the Common } \\
\text { Support }\end{array}$ & $\begin{array}{c}\text { In the Common } \\
\text { Support }\end{array}$ \\
\hline Age & 38.5 & 35.1 \\
\hline \multicolumn{3}{|l|}{ Education } \\
\hline None or Primary Incomplete & $16.8 \%$ & $12.4 \%$ \\
\hline Primary Complete or Secondary Incomplete & $34.3 \%$ & $44.4 \%$ \\
\hline Secondary Complete or Tertiary Incomplete & $37.4 \%$ & $39.7 \%$ \\
\hline Tertiary Complete & $11.5 \%$ & $3.5 \%$ \\
\hline Presence of children in the household & $50.3 \%$ & $48.0 \%$ \\
\hline Presence of other member with labor income & $67.8 \%$ & $74.8 \%$ \\
\hline Urban & $82.7 \%$ & $88.2 \%$ \\
\hline \multicolumn{3}{|l|}{ Job Category } \\
\hline Employer & $6.9 \%$ & $1.2 \%$ \\
\hline Self - Employed & $25.4 \%$ & $22.3 \%$ \\
\hline Employee & $67.7 \%$ & $76.5 \%$ \\
\hline Part-time & $16.6 \%$ & $8.7 \%$ \\
\hline Formal & $47.3 \%$ & $58.7 \%$ \\
\hline Small firm & $47.1 \%$ & $62.7 \%$ \\
\hline \multicolumn{3}{|l|}{ Occupation } \\
\hline Professionals and technicians & $16.1 \%$ & $10.3 \%$ \\
\hline Directors and upper management & $7.0 \%$ & $1.8 \%$ \\
\hline Administrative personnel and intermediary level & $9.1 \%$ & $10.3 \%$ \\
\hline Merchants and sellers & $12.0 \%$ & $13.0 \%$ \\
\hline Service workers & $16.2 \%$ & $22.6 \%$ \\
\hline Agricultural workers and similar & $12.1 \%$ & $11.8 \%$ \\
\hline Non-agricultural blue-collars, drivers and similar & $26.1 \%$ & $29.6 \%$ \\
\hline Armed forces & $0.0 \%$ & $0.0 \%$ \\
\hline Occupations not classified above & $1.4 \%$ & $0.7 \%$ \\
\hline \multicolumn{3}{|l|}{ Economic Sector } \\
\hline Agriculture, Hunting, Forestry and Fishing & $12.5 \%$ & $11.8 \%$ \\
\hline Mining and Quarrying & $1.3 \%$ & $0.1 \%$ \\
\hline Manufacturing & $16.5 \%$ & $17.2 \%$ \\
\hline Electricity, Gas and Water supply & $1.1 \%$ & $0.1 \%$ \\
\hline Construction & $7.3 \%$ & $7.2 \%$ \\
\hline Wholesale and Retail Trade and Hotels and Restaurants & $23.7 \%$ & $24.3 \%$ \\
\hline Transport, Storage & $8.0 \%$ & $4.7 \%$ \\
\hline Financing Insurance, Real Estate and Business Services & $5.7 \%$ & $1.1 \%$ \\
\hline Community, Social and Personal Services & $23.8 \%$ & $33.5 \%$ \\
\hline Wage (as percentage of Average Minorites Wage) & $153.8 \%$ & $116.6 \%$ \\
\hline
\end{tabular}

Source: Authors' calculations using Household Surveys circa 2005.

Next, we report the gap disaggregated by country for three selected sets of control variables, revealing high cross-country heterogeneity. Both the total gap and the unexplained gap after controlling by gender and age are more than two times greater in Guatemala than in Chile. Also, the effect of controlling by education differs substantially from country to country. For instance, while in Ecuador the unexplained component is no longer significantly different from 
zero after accounting for differences in education, in Brazil it only falls from 39 percent to 30 percent. This result is driven by the fact that the gap in educational attainment differs substantially between this two countries. In Ecuador, the percentage of workers with complete tertiary education is 16 percent among the non-minorities but only 6 percent among minorities. In Brazil, this difference is substantially lower as only 5 percent of non-minority workers have completed tertiary education compared to 4 percent of minorities. ${ }^{10}$

\section{Table 10. Raw and Unexplained Ethnic Wage Gap, by Country}

\begin{tabular}{|c|c|c|c|c|c|}
\hline \multirow[t]{2}{*}{ Country } & \multirow{2}{*}{$\begin{array}{c}\Delta \\
\\
{[\%]}\end{array}$} & \multicolumn{4}{|c|}{$\Delta 0$} \\
\hline & & $\begin{array}{c}\text { Gender and age } \\
{[\%]}\end{array}$ & $\begin{array}{c}\text { Gender, age } \\
\text { and education } \\
{[\%]}\end{array}$ & $\begin{array}{l}\text { + Presence of } \\
\text { children in the HH, } \\
\text { Presence of other } \\
\text { income earner in the } \\
\text { HH and Urban [\%] }\end{array}$ & $\begin{array}{l}\text { + Part-time, } \\
\text { Formality, } \\
\text { Occupation, } \\
\text { Economic Sector, } \\
\text { Type of Employment } \\
\text { and Small Firm [\%] }\end{array}$ \\
\hline Bolivia & 30.58 & $35.61 *$ & $16.50 *$ & $12.07 *$ & $21.23 *$ \\
\hline Brasil & 38.57 & $38.61 *$ & $29.99 *$ & $27.24 *$ & $13.09 *$ \\
\hline Chile & 30.81 & $29.34 *$ & $10.63 *$ & $8.40 *$ & 1.36 \\
\hline Ecuador & 30.74 & $26.71 *$ & 3.85 & 2.57 & 0.68 \\
\hline Guatemala & 67.73 & $67.44^{*}$ & $23.52 *$ & $21.03 *$ & $11.04^{*}$ \\
\hline Peru & 45.50 & $45.60 *$ & $20.92 *$ & $17.47 *$ & $14.44 *$ \\
\hline Paraguay & 59.64 & $58.01 *$ & $21.77 *$ & $12.25 *$ & 6.03 \\
\hline Latin America & 37.78 & 39.50 & 27.90 & 25.11 & 12.88 \\
\hline
\end{tabular}

Source: Authors' calculations using Household Surveys circa 2005.

*Statistically different than zero at the $99 \%$ level

Next, the four components of the wage gap by country (sorted by the magnitude of the unexplained component), for the specification with the richer set of control variables, are presented in Figure 4. As in the case of the gender gap, there are clear qualitative patterns for the components across countries. First, $\Delta_{X}$ is positive in every country, reflecting that in every country minorities have combinations of characteristics that are related to lower payoffs in the labor markets than the characteristics of non-minorities (in particular, educational attainment). Second, $\Delta_{W}$ is positive in all countries as well, and it represents the highest component in most of them. This suggests than in every country the existence of combinations of characteristics that

\footnotetext{
${ }^{10}$ This is not to say that Brazil has actually been successful in closing the gap in educational attainment between minorities and non-minorities, but that educational attainment is low for both minorities and non-minorities.
} 
are only reached by non-minorities do play an important role in explaining part of the wage gap. The access barriers that we are hypothesizing as explanation for the wage gaps prevail in all countries. Unexplained ethnic wage gaps $\left(\Delta_{0}\right)$ are also positive in all countries (although it is not significantly different from zero in Chile, Ecuador and Paraguay).

\section{Figure 4. Ethnic Wage Gaps Decompositions By Country}

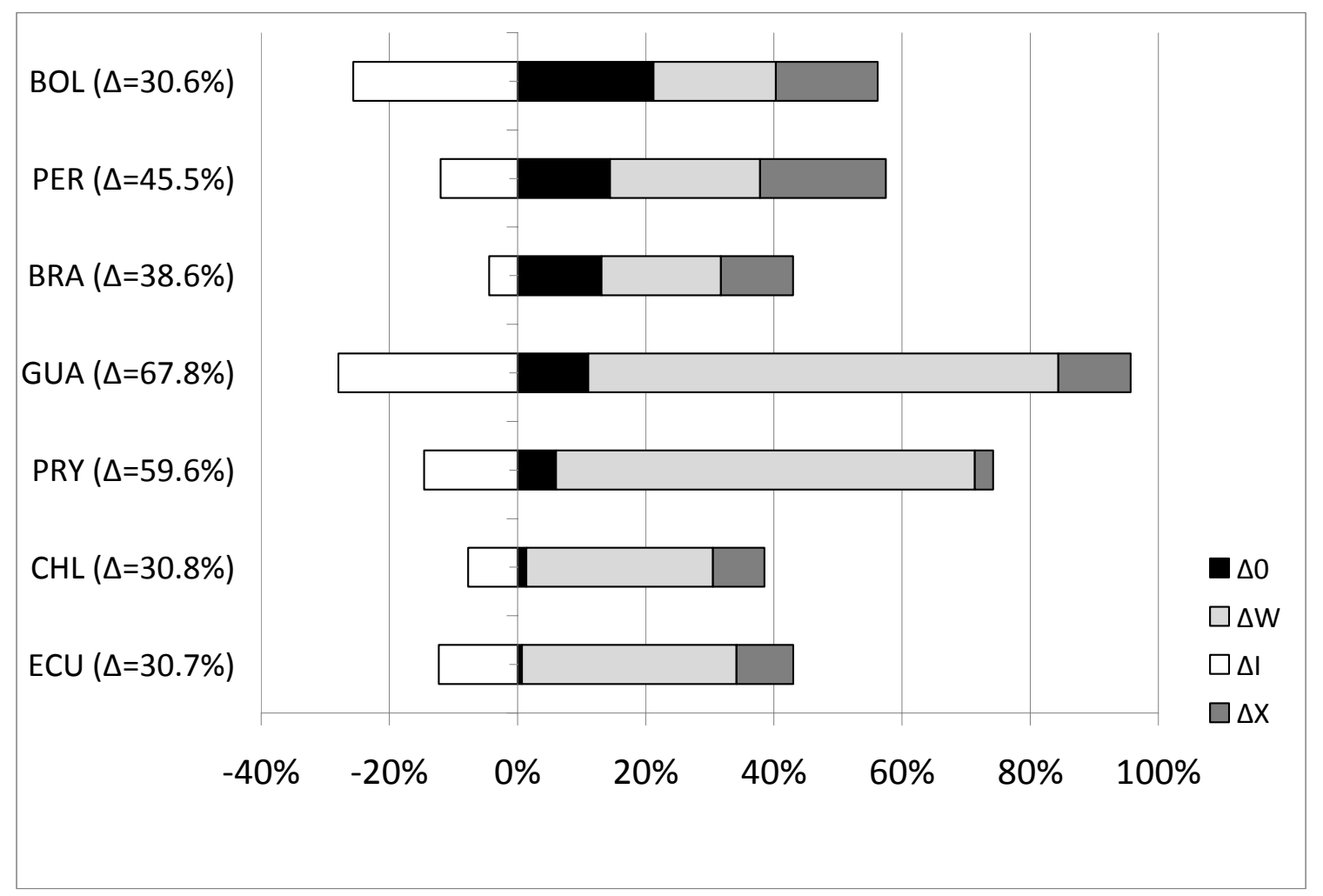

Source: Authors' calculations using Household Surveys circa 2005.

Interesting features arise when exploring the distribution of the unexplained gaps across observable characteristics (Figure 5). First, the ethnic wage gap is higher among males than among females.. Nonetheless, this does not contradict the fact females minorities are those who fare the worst in the labor markets. As a matter of fact, the wage gap that exists between female minorities and male non-minorities reaches an astonishing 60 percent when no control variables are used. Most of such "extreme" gap can not be explained on the basis of observable characteristics (socio-demographic and job-related). Out of the components attributable to 
observable characteristics the highest is the one explained by combinations of characteristics that white males achieve but indigenous females do not. ${ }^{11}$

Second, the unexplained ethnic wage gap is smallest among the youngest. As already discussed in the case of gender where a similar finding was reported, this may contain good news, but the evidence is not definitive. The good news would be that younger cohorts are able to enter into the labor markets facing less discriminatory behaviors and then getting closer to the "equal pay for equal productive characteristics” paradigm that this matching approach measures. The word of caution is that this finding may reflect the effect of unobservables correlated with age.

Third, those with other labor income generators in the household face smaller ethnic wage gaps than those who are the sole income generator at home. Fourth, unexplained ethnic wage gaps are lower in urban areas when compared to the rural ones. Fifth, unexplained ethnic wage gaps are lower and more disperse among part-time workers than among those who work full-time. Sixth, wage gaps are clearly more dispersed at both extremes of the educational attainment distribution.

\footnotetext{
${ }^{11}$ This last decomposition exercise is not reported on the tables but it is available form the authors upon request.
} 
Figure 5. Confidence Intervals for the Unexplained Ethnic Wage Gap (after controlling for demographic and job related characteristics), by Different Characteristics
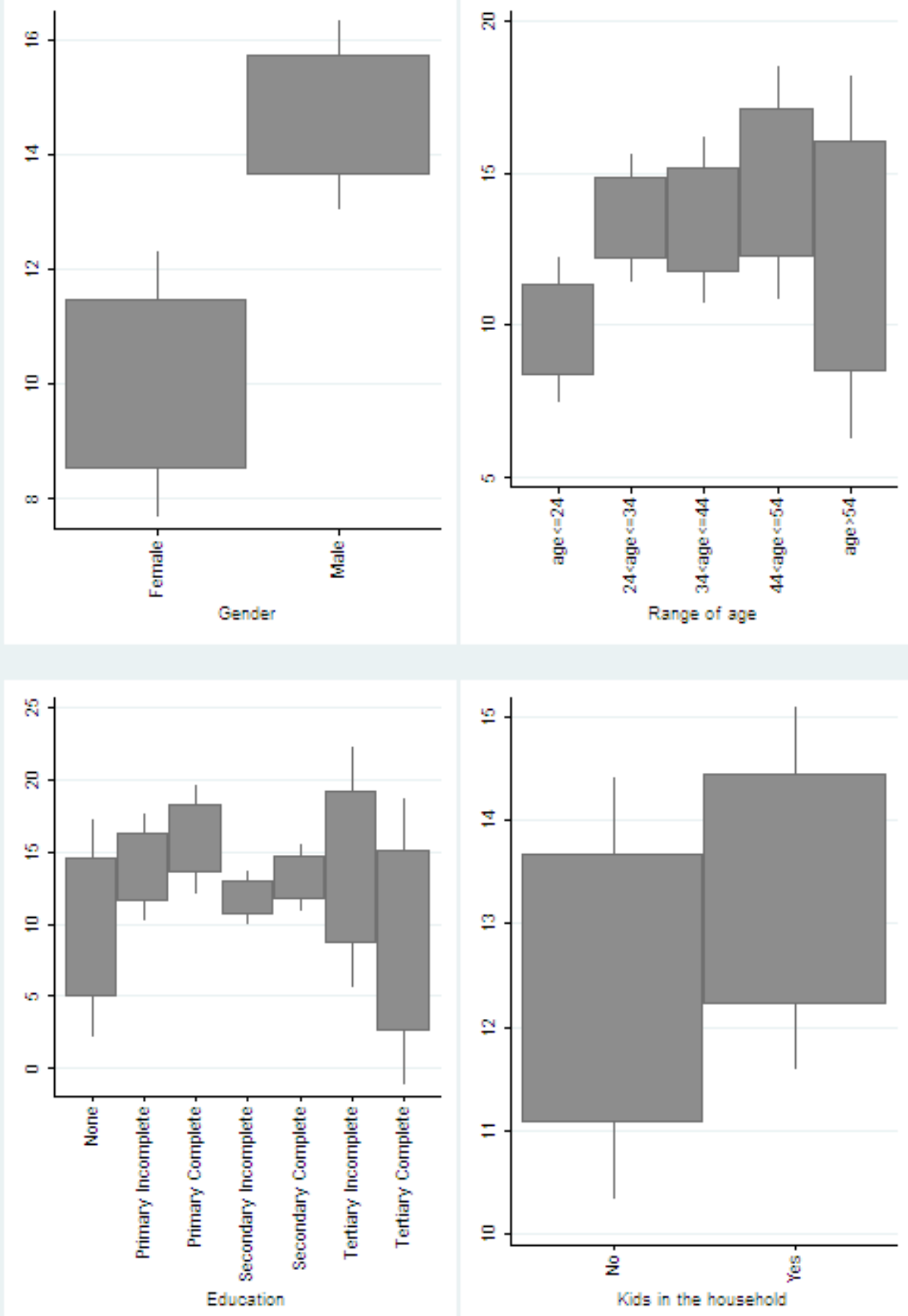

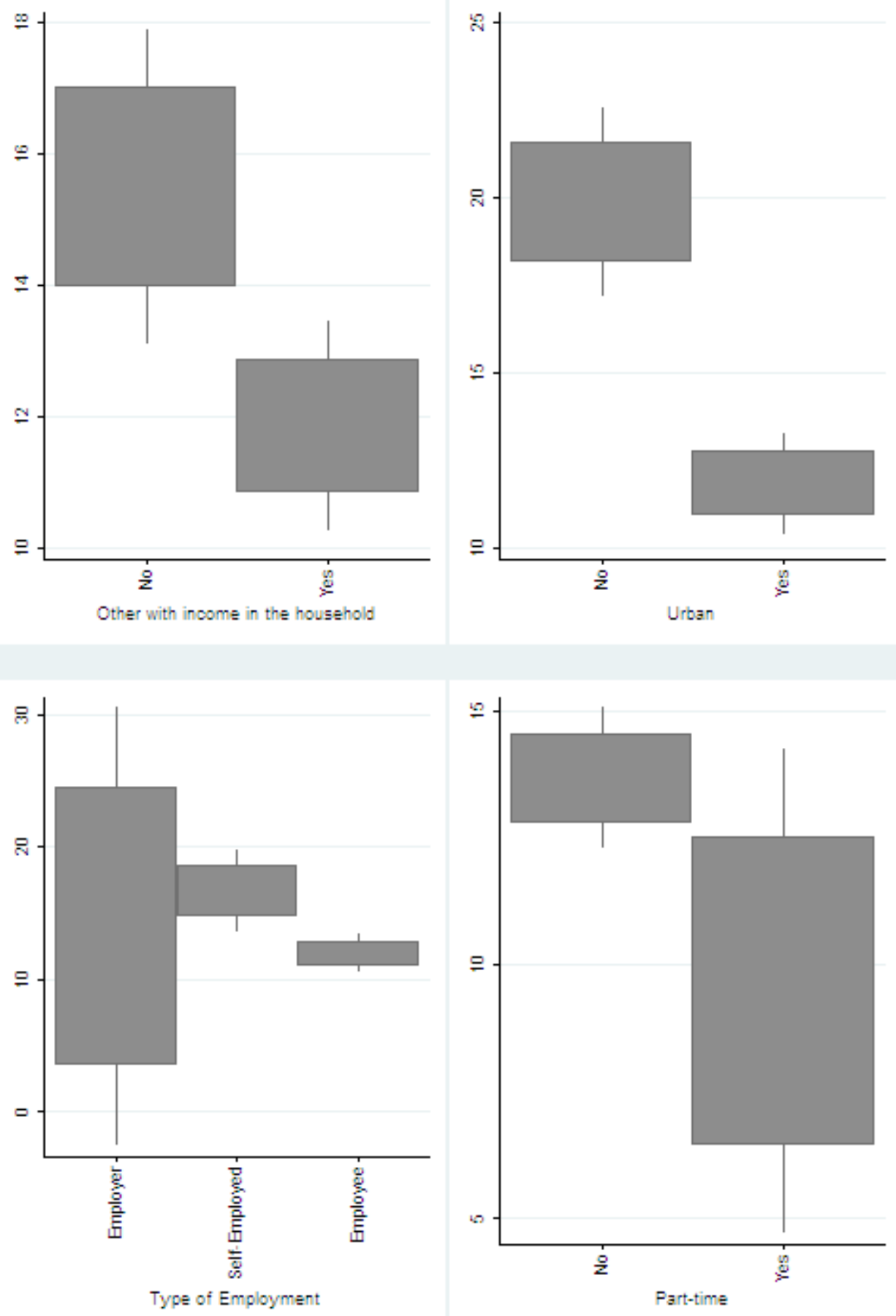

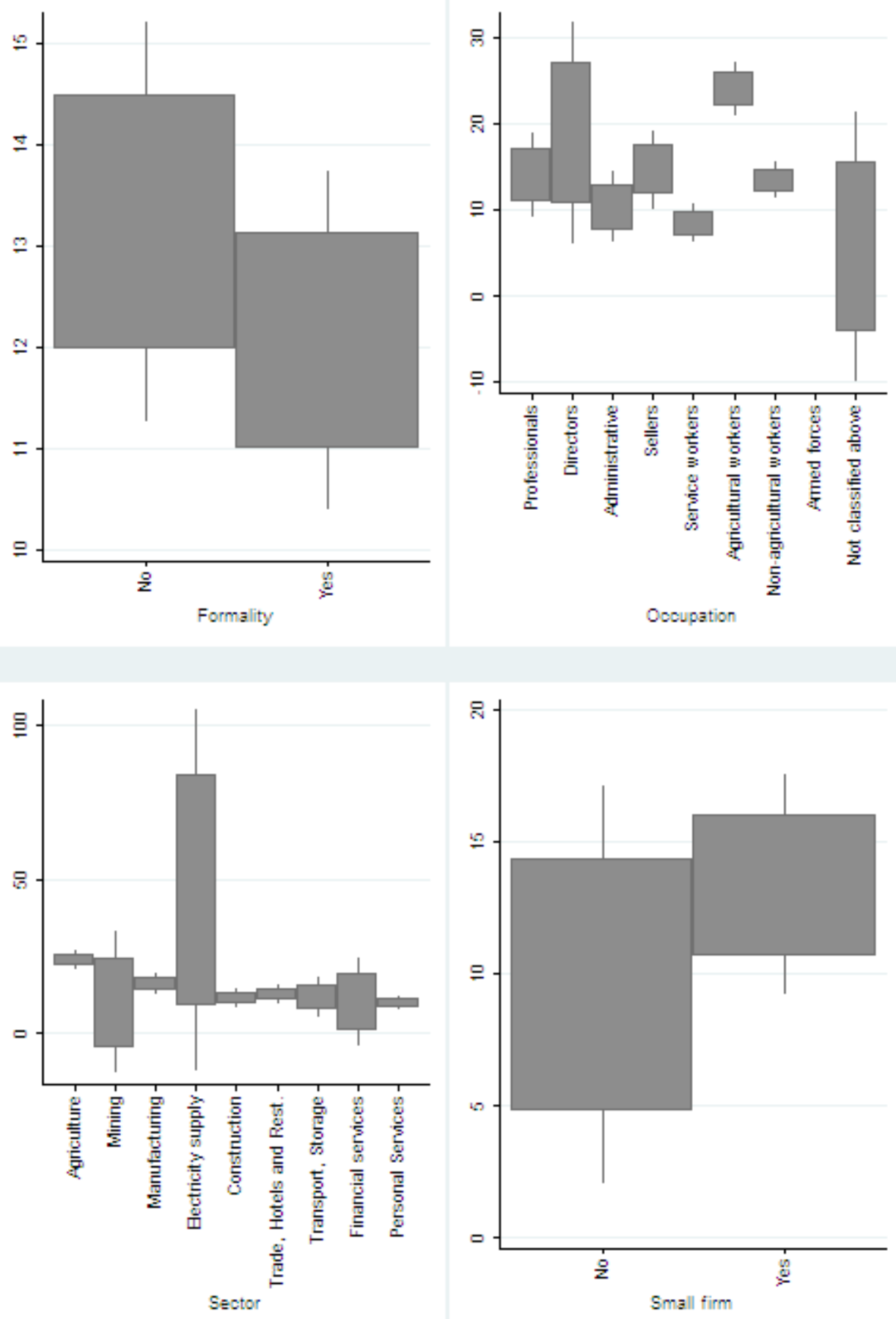

Source: Authors' calculations using Household Surveys circa 2005. 
As in Section 3, Figure 6 presents the unexplained ethnic wage gap for different percentiles of wage distributions of minorities and non-minorities to assess whether the unexplained component is concentrated, as in the case of the gender gap, in some particular segments of the wage distributions.

When controlling only for gender and age, the unexplained gap is significantly higher among low-income workers. The gap is over 100 percent at the bottom of the distributions and decreases sharply until the $30^{\text {th }}$ percentile, where it is close to 27 percent. The gap then presents a slightly upward pattern and closes only at the very right-end of the distribution. When education is added as a matching variable, the overall pattern described above is almost maintained, with a reduction in the unexplained component of the ethnic wage gap. Note, however that the highest reductions in the gap occur at the lower percentiles of the distributions. In other words, differences in wages are better explained by differences in educational attainment among lowincome workers than among the middle or high-income workers. After controlling for demographic and job-related characteristics, the unexplained gap becomes roughly homogenous along the wage distribution. 
Figure 6. Unexplained Ethnic Wage Gap by Percentiles of the Wage Distribution

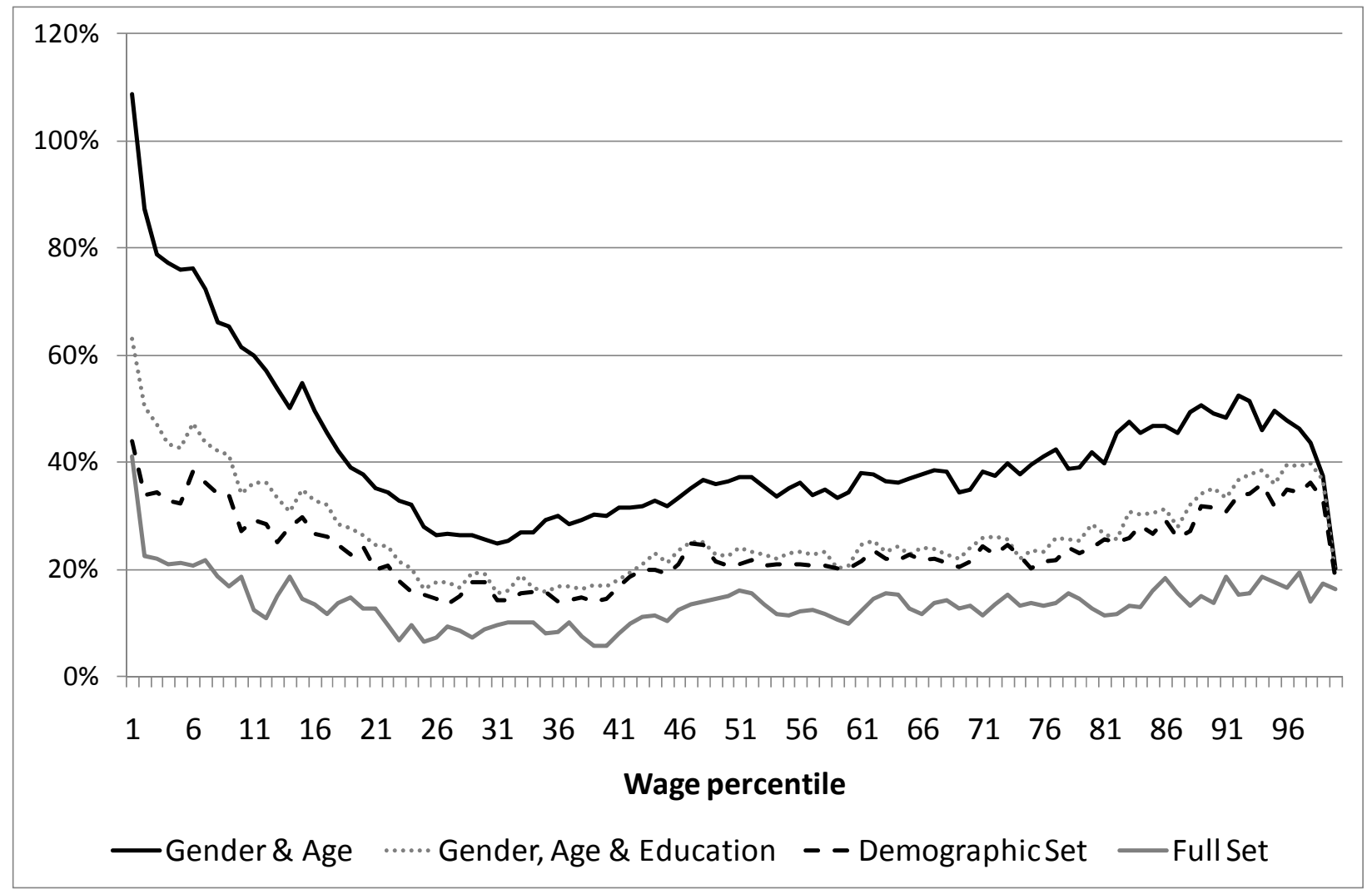

Source: Authors’ calculations using Household Surveys circa 2005.

\section{Conclusions}

The literature has widely documented the existence of poorer labor market outcomes among women and ethnic minorities in Latin America. This paper reviews the literature on such gaps and contributes to it by providing comparative evidence for a widespread representative sample of Latin America. Also, this paper approaches the analysis of wage gaps with a novel technique. Using a non-parametric matching approach as an extension to the traditional Blinder-Oaxaca decompositions, this paper disentangles the sources of wage gaps in terms of observable characteristics.

Latin American men are found to earn on average 10 percent more than women despite their lower educational attainments. Our estimations suggest that, should women have the same characteristics than men (in particular the same educational attainment), the gender wage gap would jump to almost 20 percent of females' average wage. Nonetheless, within these averages 
we find substantial cross-country heterogeneity. After controlling for observable demographic and job-related characteristics, the unexplained gender wage gap is statistically insignificant in Ecuador but reaches 28 percent in Nicaragua. Importantly, the effect of controlling by the differences in educational attainment differs substantially across countries. For instance, while in Argentina the unexplained portion of the gap after controlling by age and education is 30 times higher than the raw gap, there is no sizeable effect of controlling by education in Peru. This is a reflection of the heterogeneity of gender differences in educational attainment.

It is interesting to note that the unexplained gender wage gap is lower among those with tertiary education. Both supply and demand factors could drive this result. On the one hand, educated women may be less prone to accept lower wages than their male counterparts, and also to work in firms where there is less room for discretionary wage-setting. The latter hypothesis is supported by the fact that the unexplained wage gap is found to be lower among formal workers. In a related result, gender wage gaps are found to be larger among low wage earners, especially among the lowest decile of the wage distribution.

The unexplained gender wage gap increases with age, which could be explained by a cohort effect or by the effect of some unobservable traits, like experience, for which gender differences are likely to be correlated with age. Differences in accumulated experience could be exacerbated over time as women age and have children. Indeed, we find that the unexplained component of the gender gap is slightly higher among workers with children. The results show no differences in the average unexplained gender wage gaps between part-time and full-time workers, but more dispersion on the former. This may be a reflection of the high heterogeneity in constrains and motivations that females face when deciding to work part-time.

Unexplained gender wage gaps are higher among the self employed. This defies the common view that gender wage gaps are most likely to be found due to employer-based discrimination, while reaffirms in turn previous findings of considerable gender differences in the quality of self-employment. Our findings do not provide strong evidence for an important role of occupational segregation in explaining the gender wage gaps. Our findings regarding economic sector segregation, however, points towards a result that challenges previous perceptions based on no systematic evidence. Even if gender differences in labor allocation across economic sectors are large, they are not a factor increasing wage differentials. Without 
gender segregation in economic sectors the observed gender wage gaps would be even higher than their actual value.

The total ethnic wage gap (before controlling for observable characteristics) is found to be considerably higher than the total gender wage gap, reaching more than 38 percent of minorities' wages. Ethnic gaps in educational attainment are found to be large in the region, which allow us to explain almost one-fourth of the wage gap, but still, an important portion of the gap remains unexplained. The unexplained wage gap reaches almost one third of the total wage gap (13 percent). As in the case of gender, we find high cross-country heterogeneity. Also, the effect of controlling by education differs substantially across countries, mainly due to remarkable differences in educational attainment gaps. The unexplained component of the wage gap is substantially reduced in countries with high educational attainment gaps such as Ecuador. On the other hand, in countries like Brazil where non-minorities are as poorly educated as minorities, the gap cannot be explained by education. We find that the unexplained wage gap is considerably more disperse at both extremes of the educational attainment distribution.

A distinctive feature of ethnic wage gaps is that they are lower among part-time workers than among full-time workers. Even if we do not find a strong impact of economic sector segregation on wage gaps, we do find, in contrast with the results obtained for the gender analysis, that the ethnic wage gap is linked to occupational segregation. The presence of nonminorities having combinations of productive characteristics not attainable by minorities explains an important part of the gap. More than 21 percentage points out of the 39 percentage points of the wage gap (that is, slightly more than half of the wage gap) is attributable to the existence of non-minorities with combinations of characteristics that are not realized among minorities. These are highly paid profiles of older and educated workers holding a position of professional or director or upper management in some specific sectors of the economy. In this sense, we find evidence that ethnic minorities in the region are confronted with "glass ceilings" or access barriers while trying to obtain high-paid positions.

In sum, this paper provides evidence that the region still faces major challenges in terms of eradicating labor market disadvantages based on characteristics like gender or ethnicity. Policies that are aimed at reducing these inequalities are still in need, not only because of ethical considerations regarding equality but as major strategy to reduce poverty in the region. Even though policies aimed at boosting school attendance for minorities are welcomed, they should 
also take into account the lower incentives to schooling completion that the labor market is posing for indigenous minorities; even with minorities' lower educational attainment, returns to schooling completion for the minorities are found to be lower than for non-minorities. As ethnic minorities and women are in a disadvantaged position, indigenous girls in the region should be given special attention. 


\section{References}

Abramo, L., and M.E. Valenzuela. 2005. “Women’s Labor Force Participation Rates in Latin America.” International Labour Review 144(4).

Acosta, F. 2007. “Discriminación por Género.” Santiago, Chile: Consejo Asesor Presidencial, Trabajo y Equidad. http://www.trabajoyequidad.cl/documentos/temp/discriminaciongenero.pdf

Acosta, P., and L. Gasparini. 2007. “Capital Accumulation, Trade Liberalization, and Rising Wage Inequality: The Case of Argentina.” Economic Development and Cultural Change 55: 793-812.

Actis Di Pasquale, E., and A.J. Atucha. 2003. "Brechas Salariales: Discriminación o Diferencias de Productividad.” Momento Económico 126: 23-33.

Aguero, J., and M.S. Marks. 2008. "Motherhood and Female Labor Participation: Evidence from Infertility Shocks.” American Economic Review 98(2): 500-504.

Alejandra, C., and J. Roberts. 1993. "Macroeconomic Influences on Female Labor Force Participation: The Latin American Evidence.” Estudios de Economia 20: 87-106.

Alejos, L.A. 2003. “Contribution of the Determinants of income inequality in Guatemala.” Guatemala City, Guatemala: Universidad Rafael Landivar, Instituto de Investigaciones Económicas y Sociales. http://www.uwcades.org/papers/alejos2003.pdf

Altonji, J.G., and R.M. Blank. 1999. "Race and Gender in the Labor Market.” In: G.M. Grossman and K. Rogoff, editors. Handbook of Labor Economics. Volume 3. Amsterdam, The Netherlands: Elsevier.

Andersen, L., A. Mercado and B. Muriel. 2003. “Discriminación étnica en el sistema educativo y mercado de trabajo de Bolivia.” Latin American Journal of Economic Development 1: 69-98.

Angel-Urdinola, D.F., and Q. Wodon. 2006. “The Gender Wage Gap and Poverty in Colombia.” Review of Labour Economics and Industrial Relations 20(3): 721-739.

Angrist, J.D., and W.N. Evans. 1998. "Children and Their Parents' Labor Supply: Evidence from Exogenous Variation in Family Size." American Economic Review 88(3): 450-577.

Arabsheibani, G.R., F.G. Carneiro and A. Henley. 2003. “Gender Wage Differentials in Brazil: Trends over a Turbulent Era.” World Bank Policy Research Working Paper 3148. Washington, DC, United States: World Bank. 
Arcand, J.L., and B. D’Hombres. 2004. "Racial Discrimination in the Brazilian Labour Market: Wage, Employment and Segregation Effects.” Journal of International Development 16: 1053-1066.

Arends, M. 1992. "Female Labor Force Participation and Earnings in Guatemala." In: G. Psacharopoulos and Z. Tzannatos, editors. Case Studies on Women's Employment and Pay in Latin America. Washington, DC, United States: World Bank.

Arias, O., G. Yamada, and L. Tejerina. 2004. "Education, Family Background and Racial Earnings Inequality in Brazil.” International Journal of Manpower 25(3/4): 355-74.

Artecona, R., and W. Cunningham. 2002. "Effects of Trade Liberalization on the Gender Wage Gap in Mexico.” Washington, DC, United States: World Bank. http://siteresources.worldbank.org/INTGENDER/Resources/tradeartecona.pdf

Astudillo, A., and M. Perticará. 2008. “¿Qué Tan Alta Puede Ser la Brecha de Salarios en Chile? Investigando Diferencias Salariales entre Hombres y Mujeres a Partir de Regresiones de Cuántiles.” ILADES-Georgetown University Working Papers 211. Washington, DC, United States: Georgetown University. http://www.economia.uahurtado.cl/pdf/publicaciones/inv211.pdf

Badel, A., and X. Peña. 2009. "Decomposing the Gender Wage Gap with Sample Selection Adjustment: Evidence from Colombia.” Bogotá, Colombia: Universidad de las Andes. Mimeographed document. Available at: http://ximena.pena.googlepages.com/gender.pdf Barrientos, A. 2002. "Women, Informal Employment and Social Protection in Latin America." IDPM University of Manchester. IDPM Discussion Paper 30557. Manchester, United Kingdom: University of Manchester, Institute for Development Policy and Management.

Barron, M. 2008. "Exclusion and Discrimination as Sources of Inter-Ethnic Inequality in Peru." Economia 31(61): 51-80.

Barros, R., L. Ramos, and E. Santos. 1995. “Gender Differences in Brazilian Labor Markets.” In: T.P. Schultz, editor. Investment in Women's Human Capital. Chicago, United States: University of Chicago Press.

Barsky, R. et al. 2002. "Accounting for the Black-White Wealth Gap: A Nonparametric Approach.” Journal of the American Statistical Association 97: 663-673.

Benvin, E., and M. Perticara. 2007. “Análisis de los Cambios en la Participación Laboral Femenina en Chile.” Revista de Análisis Económico 22(1): 71-92. 
Bernal, R. and M. Cárdenas. 2005. "Race and Ethnicity in Health and Health Care in Colombia.” Washington, DC, United States: Inter-American Development Bank. Mimeographed document.

Bernat, L.F., and J. Vélez Robayo. 2008. “Los Hombres al Trabajo y las Mujeres a la Casa: Es la Segregación Ocupacional Otra Explicación Razonable de las Diferencias Salariales por Sexo en Cali?” Borradores de Economía y Finanzas 16. Cali, Colombia: Universidad ICESI.

Bertrand, M., L. Erzo and M. Sendhil. 2000. “Network Effects and Welfare Cultures.” Quarterly Journal of Economics 115(3): 1019-1055.

Birdsall, N., and M.L. Fox. 1985. "Why Males Earn More: Location and Training of Brazilian Schoolteachers.” Economic Development and Cultural Change 33(3): 533-556.

Blinder, A. 1973. “Wage Discrimination: Reduced Form and Structural Differences.” Journal of Human Resources 7(4): 436-55.

Borja-Vega, C., T. Lunde and V. García Moreno. 2007. “Economic Opportunities for Indigenous Peoples in Mexico.” In: Conference Edition: Economic Opportunities for Indigenous Peoples in Latin America. Washington, DC, United States: World Bank.

Bravo, D., C. Sanhueza and S. Urzúa. 2008a. “An Experimental Study of Labor Market Discrimination: Gender, Social Class and Neighborhood in Chile.” Research Network Working Paper R-541. Washington, DC, United States: Inter-American Development Bank.

----. 2008b. “Ability, Schooling Choices and Gender Labor Market Discrimination: Evidence for Chile.” Research Network Working Paper R-558. Washington, DC, United States: InterAmerican Development Bank.

Brown, R.S., M. Moon and B.S. Zoloth. 1980. "Incorporating Occupational Attainment in Studies of Male/Female Earnings Differentials.” Journal of Human Resources 15(1): 328.

Brown, C.J., J.A. Pagán, and E. Rodríguez-Oreggia. 1999. “Occupational Attainment and Gender Earning Differentials in Mexico.” Industrial and Labor Relations Review 53(1).

Cacopardo, M.C., and A.M. Maguid. 2001. “Argentina: International Migrants and Gender Inequality in the Labour Market.” Paper presented at the XXIV General Population Conference, Salvador, Brazil. 
Calla, R. 2007. La Mujer Indígena en Bolivia, Brasil, Ecuador, Guatemala y Panama: Un Panorama de Base a Partir de la Ronda de Censos de 2000. Serie Mujer y Desarrollo. Santiago, Chile: Consejo Económico para América Latina y el Caribe.

Calónico, S., and H. Ñopo. 2008. "Gender Segregation in the Workplace and Wage Gaps: Evidence from Urban Mexico, 1994-2004.” Research Department Working Paper 636. Washington, DC, United States: Inter-American Development Bank.

Calvó-Armengol, A., and M.O. Jackson. 2007. "Social Networks in Labor Markets: Wage and Employment Dynamics and Inequality.” Journal of Economic Theory 132(1): 27-46.

Camargo, J.M., and F. Serrano. 1983. "Os dos Mercados: Homens e Mulheres na Industria Brasileira.” Revista Brasileira de Economia 37(4).

Campante, F.R., A.R.V. Crespo and P.G. Leite. 2004. "Desigualdade Salarial entre Raças no Mercado de Trabalho Urbano Brasileiro: Aspectos Regionais.” Revista Brasileira de Economia 58(2).

Carvalho, A.P., M.C. Neri and D.B. Silva. 2006. "Diferenciais de Salários por Raça e Gênero: Aplicação dos procedimentos de Oaxaca e Heckman em Pesquisas Amostrais Complexas.” Ensaios Econômicos da EPGE 638. Rio de Janeiro, Brazil: Fundação Getulio Vargas, Escola de Pós Graduação de Economia (EPGE).

Chávez Castillo, S. 2006. "Mujeres Indígenas del Servicio Doméstico en la Ciudad de México: Su Lucha por el Respeto a sus Derechos Humanos, Laborales y Culturales.” Mexico City, Mexico: Asamblea de Migrantes Indígenas de la Ciudad de México. http://www.ciesas.edu.mx/proyectos/relaju/documentos/Chavez_Sandra.pdf

Chávez O’Brien, E. 2003. “Género, Empleo y Pobreza en el Perú: El Mercado Laboral Urbano, 1990-2002.” In: S. Berger, editor. Inequidades, Pobreza, Mercado de Trabajo: Bolivia y Peru. Lima, Peru: Organización Internacional de Trabajo.

Chiswick, B.R., H.A. Patrinos and M.E. Hurst. 2000. "Indigenous Language Skills and the Labor Market in a Developing Economy: Bolivia.” Economic Development and Cultural Change 48(2): 349-67.

Contreras, D., and M. Galván. 2003. “¿Ha Disminuido la Discriminación Salarial por Género y Etnia en Bolivia? Evidencia del periodo 1994-1999.” Available at: http://www.depeco.econo.unlp.edu.ar/desigualdad2003.htm 
Contreras, D., and G. Plaza. 2004. "Participación Femenina en el Mercado Laboral Chileno. ¿Cuánto Importan los Factores Culturales?” Santiago, Chile: Universidad de Chile. http://www.trabajoyequidad.cl/documentos/temp/Contreras\%20y\%20Plaza\%202004.pdf

Contreras, D., D. Kruger and D. Zapata. 2007. “Economic Opportunities for Indigenous People in Bolivia.” Washington, DC, United States: World Bank. http://siteresources.worldbank.org/EDUCATION/Resources/278200-1169235401815/Bolivia.pdf

Cox, A., and J. Roberts. 1993. "Macroeconomic Influences on Female Labor Force Participation: The Latin American Evidence.” Estudios de Economia 20: 87-106.

Cruces, G., and S. Galiani. 2007. "Fertility and Female Labor Supply in Latin America: New Causal Evidence.” Labour Economics 14(3): 565-573.

Cunningham, W., and J.P. Jacobsen. 2003. "Earnings Inequality Within and Across Gender, Racial, and Ethnic Groups in Latin America.” Wesleyan Economics Working Paper 2003-001. Middletown, United States: Wesleyan University.

Dávila, A., and J. Pagán. 1999. "Gender Pay and Occupational-Attainment Gaps in Costa Rica and El Salvador: A Relative Comparison of the Late 1980s.” Review of Development Economics 3(2): 215-230.

De Carvalho, A.P., M. Néri and D. Britz do Nascimento Silva. 2006. "Diferenciais de Salários por Raça e Gênero no Brasil: Aplicação dos Procedimentos de Oaxaca e Heckman em Pesquisas Amostrais Complexas.” Rio de Janeiro, Brazil: Instituto Brasileiro de Geografia e Estatística. Mimeographed document.

Deutsch, R. et al. 2004. "Working within Confines: Occupational Segregation by Gender in Costa Rica, Ecuador and Uruguay.” In: C. Piras, editor. Women at Work: Challenges for Latin America. Washington, DC, United States: Inter-American Development Bank.

DiNardo, J., N. Fortin and T. Lemieux. 1996. "Labor Market Institutions and the Distribution of Wages, 1973-1992: A Semiparametric Approach.” Econometrica 64(5): 1001-1044.

Donald, S., D. Green and H. Paarsch. 2000. "Differences in Wage Distributions between Canada and the United States: An Application of a Flexible Estimator of Distribution Functions in the Presence of Covariates." Review of Economic Studies 67: 609-633.

Duryea, S. et al. 2007. "The Educational Gender Gap in Latin America and the Caribbean.” Research Department Working Paper 600. Washington, DC, United States: InterAmerican Development Bank. 
Cox-Edwards, A., and J. Roberts. 1993. "Macroeconomic Influences on Female Labor Force Participation: The Latin American Evidence.” Estudios de Economia 20(9): 87-106.

Espini, A., and P. Azar. 2005. "Changes in Economic Policy Regimes in Uruguay from a Gender Perspective (1930-2000).” GEM-IWG Working Paper 06-05. Salt Lake City, United States: University of Utah, International Working Group on Gender, Macroeconomics and International Economics. http://www.econ.utah.edu/genmac/WP/06-5.pdf

Esquivel, V. 2007. “Género y Diferenciales de Salarios en la Argentina.” In: M. Novick and H. Palomino, coordinators. Estructura Productiva y Empleo: Un Enfoque Transversal. Buenos Aires, Argentina: Ministerio de Trabajo, Empleo y Seguridad Social.

Esquivel, V., and J.A. Paz. 2002. "Differences in Wages between Men and Women in Argentina Today: Is There an 'Inverse' Gender Wage Gap?’ Paper presented at the annual meeting of the Asociación Argentina de Economía Política, Tucumán, Argentina. Available at: http://www.aaep.org.ar/espa/anales/resumen_03/Esquivel_Paz.htm

Even, W.E. and D.A. Macpherson. 1990. Plant Size and the Decline of Unionism.” Economics Letters 32(4): 393-398.

Fazio, M.V. 2007. "Economic Opportunities for Indigenous Peoples in Guatemala." In: Conference Edition: Economic Opportunities for Indigenous Peoples in Latin America. Washington, DC, United States: World Bank.

Ferré, Z., and M. Rossi. 2002. "Segregación Ocupacional de la Mujer en el Mercado de Trabajo del Uruguay.” Montevideo, Uruguay: Universidad de la República, Facultad de Ciencias Sociales Departamento de Economía.

Flückiger, Y., and J.G. Silber. 1999. The Measurement of Segregation in the Labor Force. New York, United States: Springer-Verlag Telos.

Frankema, E. 2008. "Wage Gaps in Twentieth Century Latin America: Persistent Inequality or Distributional Change.” Utrecht, The Netherlands: Utrecht University. http://vkc.library.uu.nl/vkc/seh/research/Lists/Working\%20Papers/Attachments/47/Paper \%20Frankema.\%20WageInequalityLA.Complete.11.08.pdf

Freije, S. 2009. "Informal Employment in Latin America and the Caribbean: Causes, Consequences and Policy Recommendations.” Washington, DC, United States: InterAmerican Development Bank. http://www.iadb.org/sds/doc/SOCInfEmployment.pdf 
Fuentes, J., A. Palma and R. Montero. 2005. “Discriminación Laboral por Género en Chile: Una Mirada Global.” Estudios de Economía 32(2): 133-157.

Funkhouser, E. 1997. “Mobility and Labor Market Segmentation: The Urban Labor Market in El Salvador.” Economic Development and Cultural Change 46(1): 123-53.

García-Aracil, A., and C. Winter. 2006. "Gender and Ethnicity Differentials in School Attainment and Labor Market Earnings in Ecuador.” World Development 34: 289-307.

Gideon, J. 2007. “A Gendered Analysis of Labour Market Informalization and Access to Health in Chile.” Global Social Policy 7(1): 75-94.

Gill, I.A. 1992. "Is There Sex Discrimination in Peru? Evidence from the 1990 Lima Living Standards Survey.” In: G. Psacharopoulos and Z. Tzannatos, editors. Case Studies on Women's Employment and Pay in Latin America. Washington, DC, United States: World Bank.

Gindling, T.H. 1992. "Why Women Earn Less Than Men in Costa Rica In: G. Psacharopoulos and Z. Tzannatos, editors. Case Studies on Women's Employment and Pay in Latin America. Washington, DC, United States: World Bank.

Hall, G., and H.A. Patrinos, editors. 2006. Indigenous Peoples, Poverty and Human Development in Latin America. London, United Kingdom: Palgrave Macmillan.

Hansen, J., and R. Wahlberg. 1999. "Endogenous Schooling and the Distribution of the Gender Wage Gap.” Institute for the Study of Labor (IZA) IZA Discussion Paper 78. Bonn, Germany: Institute for the Study of Labor (IZA).

Hausmann, R., L.D. Tyson and S. Zahidi, editors. 2007. The Global Gender Gap 2007. Davos, Switzerland: World Economic Forum.

---2008. The Global Gender Gap 2008. Davos, Switzerland: World Economic Forum.

Heckman, J., L. Lochner and P. Todd. 2003. "Fifty Years of Mincer Earnings Regressions.” NBER Working Paper 9732. Cambridge, United States: National Bureau of Economic Research.

Hertz, T. et al. 2008. "Wage Inequality in International Perspective: Effects of Location, Sector, and Gender.” ESA Working Paper 8/08. Rome, Italy: Food and Agriculture Organization of the United Nations, Agricultural and Development Economics Division (ESA). Available at: ftp://ftp.fao.org/docrep/fao/011/ak230e/ak230e00.pdf 
Horbath, J.E. 2007. "Discriminación Laboral hacia las Mujeres en México: Aproximación Conceptual para Medir su Magnitud.” Paper presented at the $12^{\circ}$ Encuentro Nacional de la AMECIDER (Asociación Mexicana de Ciencias para el Desarrollo Regional).

Hotchkiss, J., and R.E. Moore. 1996. "Gender Compensation Differentials in Jamaica." Economic Development and Cultural Change 44(3): 657-76.

Interational Labour Organization (ILO). 2007. Modelo de Tendencias Mundiales del Empleo. Geneva, Switzerland: ILO.

Jenkins, S. P. 1994. "Earnings Discrimination Measurement: A Distributional Approach.” Journal of Econometrics 61: 81-102.

Jiménez Pozo, W., F.L. Casazola and E. Yáñez Aguilar. 2006. “Bolivia.” In: G. Hall and H.A. Patrinos, editors. Indigenous Peoples, Poverty and Human Development in Latin America. London, United Kingdom: Palgrave Macmillan.

Jones, F.L., and J. Kelly. 1984. "Decomposing Differences between Groups: A Cautionary Note on Measuring Discrimination.” Sociological Methods and Research 12(3): 323-43.

Juhn, C., K.M. Murphy and B. Pierce. 1993. "Wage Inequality and the Rise in Returns to Skill.” Journal of Political Economy 101(3): 410-442.

Khandker, S.R. 1992. "Women's Labor Market Participation and Male-Female Wage Differences in Peru.” In: G. Psacharopoulos and Z. Tzannatos, editors. Case Studies on Women's Employment and Pay in Latin America. Washington, DC, United States: World Bank.

King, M.C. 2007. “Occupational Segregation by Race and Sex in Brazil, 1989-2001.” Observatory on Inequality in Latin America Working Paper 1. Miami, United States: University of Miami, Center for Latin American Studies. Available at: http://www.sitemason.com/files/bivP9u/WORKING\%20PAPERS\%201.pdf

Koenker, R., and G. Bassett. 1978. “Regression Quantiles.” Econometrica 46: 33-50.

Larrea, C., and F. Montenegro Torres. 2006. “Ecuador.” In: G. Hall and H.A. Patrinos, editors. Indigenous Peoples, Poverty and Human Development in Latin America. London, United Kingdom: Palgrave Macmillan.

Leme, M.C. da Silva and S. Wajnman. 2000. "Tendencias de Coorte nos Diferenciais de Rendimentos por Sexo.” In: R. Henriques, organizer. Desigualdade e pobreza no Brasil. Rio de Janeiro, Brazil: Instituto de Pesquisa Econômica Aplicada. 
Lim, L.L. 2002. “Female Labour-force Participation.” Geneva, Switzerland: International Labour Organization, Gender Promotion Programme (GENPROM). Available at: http://www.un.org/esa/population/publications/completingfertility/RevisedLIMpaper.PDF

López Bóo, F., L. Madrigal and C. Pagés. 2009. “Part-Time Work, Gender and Job Satisfaction: Evidence from a Developing Country.” Research Department Working Paper 664. Washington, DC, United States: Inter-American Development Bank.

Loureiro, P.R.A., F.G. Carneiro and A. Sachsida. 2004. "Race and Gender Differentials: An Analysis for the Urban and Rural Sector in Brazil.” Journal of Economic 31(2): 129-143.

Lovell, P. 1994. “Race, Gender and Development in Brazil.” Latin American Research Review 29(3): 1-35.

----. 2000. “Race, Gender and Regional Labour Market Inequalities in Brazil.” Review of Social Economy 58(3): 277-293.

----. 2006. “Race, Gender, and Work in São Paolo, Brazil, 1960-2000.” Latin American Research Review 41(3): 63-87.

Lovell, P., and C.H. Wood. 1998. "Skin Colour, Racial Identity and Life Chances in Brazil.” Latin American Perspectives 25(3): 90-109.

MacIsaac, D.J., and H.A. Patrinos. 1995. "Labour Market Discrimination against Indigenous People in Peru.” Journal of Development Studies 32(2): 218-233.

MacKinnon Scott, K. 1992. "Female Labor Force Participation and Earnings: The Case of Jamaica.” In: G. Psacharopoulos and Z. Tzannatos, editors. Case Studies on Women`s Employment and Pay in Latin America. Washington, DC, United States: World Bank.

Madrigal Correa, A.L. 2004. “La Evolución de la Participación Laboral de la Mujer en Mexico: El Efecto del Tamaño de la Familia 1970-2000.” Mexico City, Mexico: Centro de Investigaciones y Docencia Económicas. Master’s thesis.

Marcouiller, D., V.R. de Castilla and C. Woodruff. 1997. "Formal Measures of the InformalSector Wage Gap in Mexico, El Salvador and Peru.” Economic Development and Cultural Change 45: 367-392.

Marques Garcia, L. 2007. “The Self-Selectivity Bias in Racial Wage Gap Decompositions: An Application using the Brazilian Households Survey (PNAD).” Southampton, United Kingdom: University of Southampton. MSc thesis. 
Márquez, G., and C. Pagés. 2008 "Bad Jobs, Lows Wages and Exclusion.” In: Outsiders? The Changing Patterns of Exclusion in Latin America and the Caribbean. Economic and Social Progress in Latin America Report. Washington, DC, United States: InterAmerican Development Bank.

Márquez, G., and M.F. Prada. 2007. "Bad Jobs, Low Productivity and Exclusion.” Washington, DC, United States: Inter-American Development Bank, Research Department. Mimeographed document.

Melly, B. 2006. "Estimation of Counterfactual Contributions Using Quantile Regression.” St. Gallen, Switzerland: University of St. Gallen, Swiss Institute for International Economics and Applied Research.

Monroy, E. 2008. "Equidad de Genero en el Mercado Laboral para Nicaragua." Serie de Cuadernos de Género para Nicaragua 1. Washington, DC, United States: World Bank and Inter-American Development Bank.

Montenegro, C. 2001. "Wage Distribution in Chile: Does Gender Matter? A Quantile Regression Approach.” Policy Research Report on Gender and Development Working Paper Series 20. Washington, DC, United States: World Bank, Development Research Group/ Poverty Reduction and Economic Management Network.

Montenegro, C., and R. Paredes. (1999). "Gender Wage Gap and Discrimination: A Long Term View Using Quantile Regression.” Washington, DC, United States and Santiago, Chile: World Bank and University of Chile. Mimeographed document.

Montero, R., and P. Garcés. 2009. “¿Existe Discriminación Salarial en contra de la Población Indígena en Chile?” El Trimestre Económico 76(3): 645-669.

Ng, Y.C. 1992. "Female Labor Force Participation and Gender Earnings Differentials in Argentina.” In: G. Psacharopoulos and Z. Tzannatos, editors. Case Studies on Women `s Employment and Pay in Latin America. Washington, DC, United States: World Bank.

Ñopo, H. 2009. "The Gender Wage Gap in Peru 1986-2000: Evidence from a Matching Comparisons Approach.” Research Department Working Paper 675. Washington, DC, United States: Inter-American Development Bank.

----. 2008. "Matching as a Tool to Decompose Wage Gaps.” Review of Economics and Statistics 90(2): 290-299. 
----. 2006. “The Gender Wage Gap in Chile 1992-2003 from a Matching Comparisons Perspective.” Research Department Working Paper 562. Washington, DC, United States: Inter-American Development Bank.

Ñopo, H., J. Saavedra and M. Torero. 2004. "Ethnicity and Earning in Urban Peru.” IZA Discussion Paper 980. Bonn, Germany: Institute for the Study of Labor (IZA).

----. 2007. "Ethnicity and Earnings in a Mixed-Race Labor Market." Economic Development and Cultural Change 55(4): 709-734.

Oaxaca, R. 1973. "Male-Female Wage Differentials in Urban Labor Markets.” International Economic Review 14(3): 693-70.

Oliveira, A.M.H. 2001. "Occupational Gender Segregation and Effects on Wages in Brazil.” Proceedings of XXIV General Population Conference, International Union for the Scientific Study of Population, Belo Horizonte, Brazil.

Paes de Barros, R. et al. 2009. Measuring Inequality of Opportunities in Latin America and the Caribbean. Washington, DC, United States and London, United Kingdom: World Bank and Palgrave.

Pagán, J.A. 2002. “Gender Differences in Labor Market Decisions in Rural Guatemala.” Review of Development Economics 6(3): 428-441

Pagán, J.A., and S.M. Sánchez. 2000. “Gender Differences in Labor Market Decisions: Evidence from Rural Mexico.” Economic Development and Cultural Change 48(3): 619-637.

Pagán, J.A., and M. Ullibarri. 2000. "Group Heterogeneity and the Gender Earnings Gap in Mexico.” Economía Mexicana (New Series) 9(1): 23-40.

Panizza, U., and C. Z-W. Qiang. 2005. "Public-Private Wage Differential and Gender Gap in Latin America: Spoiled Bureaucrats and Exploited Women?” Journal of SocioEconomics 34: 810-833.

Paredes, R. 1982. "Diferencias de Ingreso entre Hombres y Mujeres en el Gran Santiago 1969 y 1981.” Estudios de Economia 18: 99-121.

Paredes, R., and L. Riveros. 1994. "Gender Wage Gaps in Chile: A Long Term View: 19581990.” Estudios de Economia 21(Special Issue): 209-230.

Patrinos, H. 1997. "Differences in Education and Earnings across Ethnic Groups in Guatemala." Quarterly Review of Economics and Finance 37(4): 809-821. 
----. 2000. "The Costs of Discrimination in Latin America." Studies in Comparative International Development 35(2): 3-17.

Patrinos, H., and E. Skoufias, editors. 2007. Economic Opportunities for Indigenous Peoples in Latin America. Conference Edition. Washington, DC, United States: World Bank.

Paz, J. 1998. "Brecha de Ingresos entre Géneros (Comparación entre el Gran Buenos Aires y el Noroeste Argentino).” Paper presented at the Annual Meeting of the Asociación Argentina de Economía Política, Mendoza Argentina. Available at: http://www.aaep.org.ar/espa/anales/pdf_98/paz.pdf

Peredo Beltrán, E. 2004. “Una Aproximación a la Problemática de Género y Etnicidad en América Latina.” Serie Mujer y Desarrollo 53. Santiago, Chile: Consejo Económico para América Latina y el Caribe.

Pérez de Rada, E. 1997. "Discriminación Salarial por Género y Etnia en Ciudades Principales de Bolivia.” UDAPSO Working Paper No. 47/97. La Paz, Bolivia: Unidad de Análisis de Políticas Sociales.

Perticará, M., and A. Astudillo. 2008. “¿Qué Tan Alta Puede Ser la Brecha de Salarios en Chile? Investigando Diferencias Salariales entre Hombres y Mujeres a Partir de Regresiones de Cuantiles.” ILADES-Georgetown University Working Papers 211. Washington, DC, United States: ILADES-Georgetown University, School of Economics and Business.

Pichunman Cortés, M. 2007. "Discriminación Laboral por condición Étnica: Una Revisión de la Literatura.” Santiago, Chile: Consejo Asesor Presidencial Trabajo y Equidad. http://www.trabajoyequidad.cl/documentos/temp/discrminicaionetnica.pdf

Piras, C., editor. 2004. Women at Work: Challenges for Latin America. Washington, DC, United States: Inter-American Development Bank.

Piras, C. 2004. "An Overview of the Challenges and Policy Issues Facing Women in the Labor Force.” In: C. Piras, editor. Women at Work: Challenges for Latin America. Washington, DC, United States: Inter-American Development Bank.

Popli, G. 2008. “Gender Wage Discrimination in Mexico: A Distributional Approach.” Sheffield Economic Research Paper 2008006. Sheffield, United Kingdom: University of Sheffield. http://www.shef.ac.uk/content/1/c6/08/41/64/SERP2008006.pdf. 
Pratap, S., and E. Quintin. 2001. "Are Labor Markets Segmented in Argentina? A Semiparametric Approach.” Center for Latin America Working Papers 0701. Dallas, United States: Federal Reserve Bank of Dallas.

Psacharopoulos, G. 1992. “Ethnicity, Education, and Earnings in Bolivia and Guatemala.” Policy Research Working Paper 1014. Washington, DC, United States: World Bank.

Psacharopoulos, G., and H. Patrinos. 1994. Indigenous People and Poverty in Latin America: An Empirical Analysis. Washington, DC, United States: World Bank.

Psacharopoulos, G., and Z. Tzannatos, editors. 1992. Case Studies on Women's Employment and Pay in Latin America. Washington, DC, United States: World Bank.

Psacharopoulos G., and Z. Tzannatos. 1992. "Latin American Women's Earnings and Participation in the Labor Force.” World Bank Policy Research Working Paper 856. Washington, DC, United States: World Bank.

Ramírez, A. 2006. “Mexico.” In: G. Hall and H.A. Patrinos, editors. Indigenous Peoples, Poverty and Human Development in Latin America. London, United Kingdom: Palgrave Macmillan.

Rangel, M. 2004. “Género, Etnicidad, Pobreza y Mercado Laboral en Bolivia, Ecuador, Guatemala y Perú.” In: M.E. Valenzuela and M. Rangel, coordinators. Desigualdades Entrecruzadas: Pobreza, Género, Etnia y Raza en América Latina. Santiago, Chile: Organización Internacional de Trabajo.

Rivas, F., and M. Rossi. 2000. “Discriminación Salarial en el Uruguay 1991-1997.” Documento de Trabajo 7/2000. Montevideo, Uruguay: Universidad de la República, Facultad de Ciencias Sociales, Departamento de Economía.

Rivero, R., and W. Jiménez. 1999. "Diferencias Salariales en el Mercado de Trabajo Urbano en Bolivia, 1981-1997.” Revista de Análisis Económico 17: 24-59.

Romero, W. 2007. “Los Costos de la Discriminación Etnica en Guatemala.” In: Diagnóstico del Racismo en Guatemala. Volume 1. Guatemala City, Guatemala: Vicepresidencia de la República de Guatemala.

Salas C., and M. Leite . 2007. "Segregación Sectorial por Género: Una Comparación BrasilMéxico.” Cadernos PROLAM/USP 7(2): 241-259.

Sauma, P. 2004. “Guatemala: Desigualdades Etnica y de Género en el Mercado de Trabajo.” In: M.E. Valenzuela and M. Rangel, coordinators. 2004. Desigualdades Entrecruzadas: 
Pobreza, Género, Etnia y Raza en América Latina. Santiago, Chile: Organización Internacional de Trabajo.

Scorzafave, L.G.,and E.T. Pazello. 2007. "Using Normalized Equations to Solve the Indetermination Problem in the Oaxaca-Blinder Decomposition: An Application to the Gender Wage Gap in Brazil.” Revista Brasileira de Economia 61(4): 535-548.

Selamé, T.S. 2004. Mujeres, Brechas de Equidad y Mercado de Trabajo. Santiago, Chile: Organización Internacional de Trabajo.

Shapiro, J. 2006. "Guatemala.” In: G. Hall and H.A. Patrinos, editors. Indigenous Peoples, Poverty and Human Development in Latin America. London, United Kingdom: Palgrave Macmillan.

Silva, N.D.V. 1980. “O Preço da Cor: Diferenciais Raciais na Distribuição de Renda no Brasil.” Pesquisa e Planejamento Econômico 10(1): 21-44.

Soares, S.D.S. 2000. "O Perfil da Discriminação no Mercado de Trabalho: Homens Negros, Mulheres Brancas e Mulheres Negras.” IPEA Texto para Discussão 769. Brasilia, Brazil: Instituto de Pesquisa Econômica Aplicada (IPEA).

Sookram, S., and E. Strobl. 2008. "The Role of Educational Choice in Occupational Gender Segregation: Evidence from Trinidad and Tobago.” IZA Discussion Paper 3549. Bonn, Germany: Institute for the Study of Labor (IZA).

Steele, D. 1992. "Women's Participation Decision and Earnings in Mexico." In: G. Psacharopoulos and Z. Tzannatos, editors. Case Studies on Women's Employment and Pay in Latin America. Washington, DC, United States: World Bank.

Stelcner, M., J. Van der Gaag, W. Vijverberg. 1989. “A Switching Regression Model of PublicPrivate Sector Wage Differentials in Peru: 1985-1986.” Journal of Human Resources 26: 545-55

Stelcner, M. et al. 1992. "Labor Force Behaviour and Earnings of Brazilian Women and Men, 1980.” In: G. Psacharopoulos and Z. Tzannatos, editors. Case Studies on Women's Employment and Pay in Latin America. Washington, DC, United States: World Bank.

Tam, T. 1996. "Reducing the Gender Gap in an Asian Economy: How Important Is Women's Increasing Work Experience?” World Development 24(5): 831-844. 
Tenjo, J. 1992. "Labor Markets, the Wage Gap and Gender Discrimination: The Case of Colombia.” In: G. Psacharopoulos and Z. Tzannatos, editors. Case Studies on Women’s Employment and Pay in Latin America. Washington, DC, United States: World Bank.

Tenjo, J., R.R. Medina, and L.F. Bernat. 2004. "Evolution of Salary Differences between Men and Women in Six Latin American Countries.” In: C. Piras, editor. Women at Work: Challenges for Latin America. Inter-American Development Bank.

Tenjo, J., R. Ribeiro and L.F. Bernat. 2005. “Evolución de las Diferencias Salariales por Sexo en Seis Países de América Latina: Un Intento de Interpretación.” Document CEDE 2656. Bogota, Colombia: Universidad de los Andes, Centro de Estudios sobre Desarrollo Económico (CEDE).

Terrell, K. 1992. “Female-Male Earnings Differentials and Occupational Structure.” International Labor Review 131(4-5): 387-398.

Tiefenthaler, J. 1992. “Female Labor Force Participation and Wage Determination in Brazil 1989.” In: G. Psacharopoulos and Z. Tzannatos, editors. Case Studies on Women's Employment and Pay in Latin America. Washington, DC, United States: World Bank.

Tomal, A., and L. Johnson. 2008. “Earnings Determinants for Self-Employed Women and Men in the Informal Economy: The Case of Bogotá, Colombia.” International Social Science Review 83(1/2): 71-84.

Trivelli, C. 2005. “Los Hogares Indígenas y la Pobreza en el Perú: Una Mirada a Partir de la Información Cuantitativa.” Documento de Trabajo 141. Lima, Peru: Instituto de Estudios Peruanos.

Urdinola, A.D.F. and Q. Wodon. 2006. “The Gender Wage Gap and Poverty in Colombia.” Labour 20(4): 721-739.

Valenzuela, M.E., and M. Rangel, coordinators. 2004. Desigualdades Entrecruzadas: Pobreza, Género, Etnia y Raza en América Latina. Santiago, Chile: Organización Internacional de Trabajo.

Vélez, E., and C. Winter. 1992 “Women’s Labor Force Participation and Earnings in Colombia.” In: G. Psacharopoulos and Z. Tzannatos, editors. Case Studies on Women's Employment and Pay in Latin America. Washington, DC, United States: World Bank.

Villegas, H., and J. Núñez. 2005. “Discriminación étnica en Bolivia: Examinando diferencias regionales y por nivel de calificación.” Estudios de Economía 32(2): 201-218. 
Watson, P., and S. Sookram. 2008. "The Informal Sector and Gender in the Caribbean: The Case of Trinidad \& Tobago.” Journal of Eastern Caribbean Studies 33(4): 42-66.

Weischselbaumer, D., and R. Winter-Ebmer. 2005. "A Meta-Analysis of the International Gender Wage Gap.” Journal of Economic Surveys 19(3): 479-511.

Wellington, A.J. 1993. “Changes in the Male/Female Wage Gap: 1976-85." Journal of Human Resources 28(2): 383-409.

World Bank. 2007. Informality in LAC: A Barrier to Growth and Social Welfare. Washington, DC, United States: World Bank.

Yang, H. 1992. "Female Labor Force Participation and Earnings Differentials in Costa Rica.” In: G. Psacharopoulos and Z. Tzannatos, editors. Case Studies on Women's Employment and Pay in Latin America. Washington, DC, United States: World Bank.

Yun, M-S. 2004. "Decomposing Differences in the First Moment." Economics Letters 82(2): 275-80. 


\section{Annex}

\section{Table A1. Data Sources}

\begin{tabular}{llccc}
\hline Country & Name Of The Survey & Year & $\begin{array}{c}\text { Number of } \\
\text { Observations* }\end{array}$ & Coverage \\
\hline Argentina & Encuesta Permanente de Hogares (EPH), Segundo Semestre & 2006 & 41,287 & 31 urban regions \\
Bolivia & Encuesta Continua de Hogares (ECH) & 2006 & 4,959 & National \\
Brasil & Pesquisa Nacional por Amostra de Domicilio (PNAD) & 2007 & 133,764 & National \\
Chile & Encuesta de Caracterizacion Socioeconomica Nacional (CASEN) & 2006 & 85,968 & National \\
Colombia & Encuesta Continua de Hogares (ENH) & 2005 & 52,388 & National \\
Costa Rica & Encuesta de Hogares de Propositos Multiples (EHPM) & 2006 & 13,810 & National \\
Dominican Republic & Encuesta Nacional de Fuerza de Trabajo (ENFT) & 2003 & 9,718 & National \\
Ecuador & Encuesta de Empleo, Desempleo y Subempleo (ENEMDU) & 2007 & 15,611 & National \\
Guatemala & Encuesta Nacional de Condiciones de Vida (ENCOVI) & 2006 & 18,865 & National \\
Honduras & Encuesta Permanente de Hogares de Propositos Multiples (EPHPM) & 2007 & 23,278 & National \\
Mexico & Encuesta Nacional Empleo (ENE), Segundo Trimestre & 2004 & 131,348 & National \\
Nicaragua & Encuesta Nacional de Hogares sobre medicion de Niveles de Vida (EMN 2005 & 9,838 & National \\
Panama & Encuesta de Hogares (EH) & 2003 & 17,368 & National \\
Paraguay & Encuesta Permanente de Hogares (EPH) & 2006 & 5,592 & National \\
Peru & Encuesta Nacional de Hogares (ENAHO) & 2006 & 27,665 & National \\
El Salvador & Encuesta de Hogares de Propositos Multiples (EHPM) & 2005 & 16,856 & National \\
Uruguay & Encuesta Continua de Hogares (ECH) & 2005 & 20,351 & Urban \\
Venezuela & Encuesta de Hogares Por Muestreo (EHM), Segundo Semestre & 2004 & 47,880 & National \\
\hline \hline
\end{tabular}

* Workers between 18 and 65 , after eliminating observations with incomplete data or outliers in wage

Table A2. Definition of Ethnic Minorities, by Country

\begin{tabular}{|c|c|c|c|}
\hline Country & & Criterion & $\begin{array}{l}\text { Percentage of workers } \\
\text { (12 - } 65 \text { years old) self- } \\
\text { declared as minorities }\end{array}$ \\
\hline Bolivia & Self declaring as being: & $\begin{array}{l}\text { Quechua, Aymara, Guarani, } \\
\text { Chiquitano, Mojeño or other }\end{array}$ & 52.58 \\
\hline Brasil & Having colour of skin: & Black or brown & 48.47 \\
\hline Chile & Self declaring as being: & $\begin{array}{l}\text { Aymara, Rapa nui, Quechua, Mapuche, } \\
\text { Atacameño, Coya, Kawaskar, Yagan, } \\
\text { Diaguita }\end{array}$ & 5.97 \\
\hline Ecuador & Self Declaring as being: & Indigenous, Black, Mulato or Other & 10.02 \\
\hline Guatemala & Self Declaring as being: & $\begin{array}{l}\text { K'iche', Q'eqchi', Kaqchikel, Mam, } \\
\text { Q'anjob'al, Achi, Ixil, Itza', Poqomchi', } \\
\text { Chuj, Awakateko, Poqomam, Ch'orti', } \\
\text { Jakalteko, Sakapulteco, Mopan, } \\
\text { Uspanteko, Tz'utujil, Sipakapense, } \\
\text { Chalchiteko, Akateko, Xinka or } \\
\text { Garifuna }\end{array}$ & 35.13 \\
\hline Paraguay & Self declaring as speaking : & Guarani (only) & 33.42 \\
\hline Peru & Self Declaring as being: & $\begin{array}{l}\text { Quechua, Aymara, From Amazonia, } \\
\text { Black, Mulato, Zambo or Other }\end{array}$ & 31.37 \\
\hline
\end{tabular}


Table A3.

Country Literature Review

\begin{tabular}{|c|c|c|c|}
\hline $\begin{array}{c}\text { Authors and } \\
\text { Year }\end{array}$ & Data & Main findings & Methodology \\
\hline Argentina & & Gender Gaps: Reverse gender wage gap? & \\
\hline $\mathrm{Ng}(1992)$ & $\begin{array}{l}1985 \text { Buenos Aires } \\
\text { Household Survey } \\
\text { Data }\end{array}$ & $\begin{array}{l}\text { Started discussion on earning differentials in Argentina. In a highly urban labor market, better -educated prime-age single } \\
\text { women are more likely to enter the labor Argentine labor market. An increase in human capital endowments will decrease } \\
\text { the existing wage gap, but other factors may also come into play, such as occupational segregation, job mobility. }\end{array}$ & Oaxaca decomposition \\
\hline \multirow[b]{2}{*}{ Paz (1998) } & \multirow[b]{2}{*}{ EPH 1997} & $\begin{array}{l}\text { Examines wage differentials between men and women in Greater Buenos Aires and Argentina's Northeastern areas. In all } \\
\text { variables reviewed, women receive lower wages than men, except for women with professional scientific skills and those } \\
\text { working over } 45 \text { hours/week. }\end{array}$ & \multirow{2}{*}{$\begin{array}{l}\text { Descriptive statistics; } \\
\text { Duncan Index; } \\
\text { Blinder-Oaxaca } \\
\text { Decomposition }\end{array}$} \\
\hline & & $\begin{array}{l}\text { Human capital endowments (rate of returns to education and experience) are important in explaining some differences in } \\
\text { labor force participation and wage. Among occupational variables, the level of skill of a specific task/occupation determines } \\
\text { differentials, highlighting the importance of vertical segregation. However, } 90 \% \text { of the wage differential remains } \\
\text { unexplained. }\end{array}$ & \\
\hline $\begin{array}{c}\text { Pratap and } \\
\text { Quintin (2001) }\end{array}$ & $\begin{array}{l}\text { Argentina's } \\
\text { household survey } \\
\text { (1993-1995)- urban } \\
\text { centers }\end{array}$ & $\begin{array}{l}\text { Evaluation of hypothesis that informal workers would expect higher wages in formal sector. Authors found no evidence of a } \\
\text { formal sector wage premium in Buenos Aires and its suburbs. While wages are higher on average in the formal sector, this } \\
\text { apparent premium disappears after controlling semi-parametrically for individual and establishment characteristics. }\end{array}$ & $\begin{array}{l}\text { semi parametric } \\
\text { matching estimator }\end{array}$ \\
\hline $\begin{array}{c}\text { Actis and } \\
\text { Atucha (2003) }\end{array}$ & EPH 2000 & $\begin{array}{l}\text { Mar del Plata regional study to show wage disparities at the local level (urban areas). Study was done in an area where } \\
\text { women are highly overrepresented in the services sector. } \\
\text { Results show, that women's salaries represent } 74 \% \text { of men's. The gap is reduced when education and occupation variables } \\
\text { are introduced, but is not closed entirely. The authors conclude that } 32 \% \text { of the difference can be explained by human } \\
\text { capital endowment differences; } 32 \% \text { by "clientelism" and } 36 \text { by "discrimination" against women. }\end{array}$ & $\begin{array}{l}\text { Blinder-Oaxaca - \& } \\
\text { Cotton Neumark } \\
\text { Decomposition } \\
\text { Methodologies }\end{array}$ \\
\hline $\begin{array}{c}\text { Cruces and } \\
\text { Galiani (2005) }\end{array}$ & $\begin{array}{l}\text { Arg. } 1991 \text { Census; } \\
\text { Mexico } 2000 \\
\text { Census }\end{array}$ & $\begin{array}{l}\text { Authors review linkage between fertility and labor force participation. } \\
\text { Results show that income levels (i) have a positive relationship with education attainment and b) will initially tend to } \\
\text { increase with experience, while decreasing as the worker ages. A little over a third of the wage differentials can be } \\
\text { explained by human capital characteristics. However, within the unexplained portion, } 32.5 \% \text { could be explained by male } \\
\text { advantages and } 35.6 \% \text { can be attributed to "discrimination against women. } \\
\text { The authors estimated a link between childbearing on maternal labor supply based on the thesis that parental preferences } \\
\text { for a mixed sibling sex composition can be seen as an instrument for fertility. Women who are likely to have a third child } \\
\text { searching for a balanced mix of children's sex may be less likely to enter the labor force. }\end{array}$ & $\begin{array}{l}\text { Causal IV model } \\
\text { (Abadie); OLS }\end{array}$ \\
\hline
\end{tabular}




\begin{tabular}{|c|c|c|c|}
\hline $\begin{array}{c}\text { Esquivel and } \\
\text { Paz (2002) }\end{array}$ & $\mathrm{EPH}$ & $\begin{array}{l}\text { Authors introduced the concept of an "Inverse gender wage gap" in Argentina, where the average male worker salary is } 4 \% \\
\text { less than women's; and analyze the different insertion conditions in the labor market and their influence in gender wage } \\
\text { gaps. } \\
\text { For labor markets such as Argentina, it is essential to make a distinction between regular and on-regular employment - as } \\
\text { defined by degree of job satisfaction, underemployment and relative stability. Taking these elements into account, men } \\
\text { regular workers earn } 10.2 \% \text { MORE than women regular workers, who are in turn are paid } 9 \% \text { more than non-regular women } \\
\text { workers. }\end{array}$ & $\begin{array}{l}\text { Tam model/ "A" model } \\
\text { (Models although, } \\
\text { among other things to } \\
\text { include all } \\
\text { characteristics of } \\
\text { Argentine labor market, } \\
\text { including part-time } \\
\text { workers, and informal } \\
\text { sector) }\end{array}$ \\
\hline
\end{tabular}

\begin{tabular}{|c|c|c|c|}
\hline Bolivia & & Ethnic gaps: Targeted or National Intervention? & \\
\hline $\begin{array}{l}\text { MacKinnon } \\
\text { Scott (1992) }\end{array}$ & $1989 \mathrm{EIH}$ & $\begin{array}{l}\text { Female labor force participation depends upon a series of personal and family characteristics. Women earn less than men: } \\
\text { observed differential is due to unexplained differences in the way in which the market values the two genders' labor. }\end{array}$ & $\frac{\text { Mincer equations }}{\text { Oaxaca }}$ \\
\hline $\begin{array}{c}\text { Rivero and } \\
\text { Jiménez (1999) }\end{array}$ & $\begin{array}{l}\text { Encuesta de } \\
\text { Hogares } \\
(1981 ; 85 ; 90 ; 94 ; 97)\end{array}$ & $\begin{array}{l}\text { Analysis of wage differentials shows a certain degree of gender and ethnic "discrimination" in Bolivia' urban areas. Women } \\
\text { and rural workers, particularly non-Spanish speakers, have less possibilities of receiving the same salaries as non-indigenous } \\
\text { Spanish-speaking males, despite their efforts to improve their education standing. }\end{array}$ & $\begin{array}{l}\text { Oaxaca-Blinder } \\
\text { decomposition }\end{array}$ \\
\hline $\begin{array}{l}\text { Chiswick, } \\
\text { Patrinos and } \\
\text { Hurst (2000) }\end{array}$ & $\begin{array}{l}\text { Integrated } \\
\text { Household Survey, } \\
1993\end{array}$ & $\begin{array}{l}\text { Study reviews labor market implications of limited dominant language proficiency in Bolivia. The authors' analysis on earning } \\
\text { shows men with higher salaries than women, increasing } 3.3 \% \text { per year while almost } 1 \% \text { less for women. Authors identify } \\
\text { greater investments in on-the-job training by men as a potential explanation for these disparities. Children also appear to } \\
\text { have a negative effect on women's earning, where childless married women earn } 9 \% \text { more than their peers. Earnings differ } \\
\text { significantly by language skills and are greater for women, reflecting the value of speaking Spanish in labor markets. }\end{array}$ & $\begin{array}{l}\text { Chiswick and Paul W. } \\
\text { Miller (Model to link } \\
\text { education and earnings) }\end{array}$ \\
\hline $\begin{array}{l}\text { Mercado, } \\
\text { Andersen, } \\
\text { Mercado and } \\
\text { Muriel (2003) }\end{array}$ & MECOVI 2000 & $\begin{array}{l}\text { Pre-market differentials play a key role explaining wage gaps given indigenous peoples' lower education levels and access to } \\
\text { low quality educational systems. More that } 50 \% \text { of the wage gap between indigenous and non-indigenous workers in Bolivia } \\
\text { can be explained by differences in quality of education. However, this dynamic is prevalent in the rural areas. In urban areas it } \\
\text { seems that differences may be attributable to how the market treats indigenous and non-indigenous workers, occupational } \\
\text { segregation, or certain structural characteristics of the labor market, which may tend to favor non-indigenous workers over } \\
\text { their indigenous peers. }\end{array}$ & Mincer equations \\
\hline $\begin{array}{l}\text { Contreras and } \\
\text { Galván (2003) }\end{array}$ & $\begin{array}{l}\text { Encuenta Integrada } \\
\text { de Hogares 1994; } \\
\text { MECOVI 1999 }\end{array}$ & $\begin{array}{l}\text { The contribution of this study is its focus on the evolution of wage gap trends and comparison between two demographic } \\
\text { groups: individuals older than } 10 \text { years and those between } 25 \text { and } 65 \text {. While gender discrimination increases for individuals } \\
\text { between } 25 \text { and } 65 \text { years, it decreases for those older than } 10 \text {, showing that younger women have better changes of entering } \\
\text { the labor market than their older peers. } \\
\text { Ethnic wage gaps remain stable for those between } 25 \text { and } 65 \text { or increase for those above } 10 \text { years, showing that these groups } \\
\text { have worse opportunities for labor market integration. Indigenous women have always lower wages in comparison to their } \\
\text { white male peers. Similarly to previous analyses, education explains most of ethnic wage differentials. }\end{array}$ & $\begin{array}{l}\text { Mincer equations; } \\
\text { Fields decomposition }\end{array}$ \\
\hline
\end{tabular}




\begin{tabular}{|c|c|c|c|}
\hline $\begin{array}{l}\text { Villegas and } \\
\text { Nuñez (2005) }\end{array}$ & MECOVI 2002 & $\begin{array}{l}\text { Reviews regional differences and wage differentials: ethnic discrimination in del Valle and del Llano are significant explain } \\
\text { wage differentials, such is not the case for the Altiplano region. Discrimination is also high among professional workers, but } \\
\text { not among unskilled workers. Although discrimination and productivity effects are important factors in explaining ethnic } \\
\text { wage differentials across different geographical and schooling niches of the Bolivian labor market, a significant part of the } \\
\text { overall ethnic wage gap is associated with differences in human capital endowments between both populations. }\end{array}$ & $\begin{array}{l}\text { Oaxaca-Ransom; } \\
\text { Mincer equations }\end{array}$ \\
\hline $\begin{array}{l}\text { Jimenez Pozo, } \\
\text { Landa Casazola, } \\
\text { and Yañez } \\
\text { Aguilar (2005) }\end{array}$ & MECOVI 2002 & $\begin{array}{l}\text { As part of country review, authors discuss employment and income indicators of indigenous peoples in Bolivia. They find that, } \\
\text { despite a higher rate of labor participation among indigenous peoples vis-à-vis their peers, non-indigenous peoples earn } \\
\text { higher wages. Authors argue these differentials are mainly due to differences in employment type, where most indigenous } \\
\text { individuals are involved in informal work or raising livestock. After analyzing decomposition results, authors agreed that } \\
\text { schooling and experience had the largest effect on earnings, where experience reduced wage differentials between } \\
\text { indigenous and non-indigenous workers. }\end{array}$ & Oaxaca Blinder \\
\hline $\begin{array}{l}\text { Contreras, } \\
\text { Kruger and } \\
\text { Zapata(2007) }\end{array}$ & MECOVI 2001 & $\begin{array}{l}\text { Analysis on the impact of social networks in economic decision and thus the transmission of poverty. Social networks may } \\
\text { provide an explanation for the high degree of occupational segregation among indigenous individuals. Even though social } \\
\text { networks provide important channels to access employment opportunities, and have proven to be especially key and relevant } \\
\text { for migrant families, in Bolivia these are not necessarily linked with high quality jobs. }\end{array}$ & $\begin{array}{l}\text { Regressions taking into } \\
\text { account the quality and } \\
\text { quantity of social } \\
\text { networks (Bertrand et } \\
\quad \text { al., 2000) }\end{array}$ \\
\hline Brazil & & Gender Gaps: Heterogeneity and barriers for upward mobility in labor market & \\
\hline $\begin{array}{l}\text { Birdsall and } \\
\text { Fox (1985) }\end{array}$ & Census 1970 & $\begin{array}{l}\text { The authors concentrated their analysis on a particular occupational category, schoolteachers, and found differences in } \\
\text { human capital as main explanations for existing wage differentials. }\end{array}$ & OB decomposition \\
\hline $\begin{array}{l}\text { Tiefenthaler } \\
\text { (1992) }\end{array}$ & PNAD 1989 & Wage differences in the formal and informal sector can be attributed to unobserved characteristics. & $\begin{array}{l}\text { OB decomposition with } \\
\text { correction for selection } \\
\text { bias. MNL estimation for } \\
\text { formal, informal and self- } \\
\text { employed sectors for } \\
\text { estimating the } \\
\text { participation into labor } \\
\text { market }\end{array}$ \\
\hline $\begin{array}{l}\text { Oliveira, } \\
\text { (2001) }\end{array}$ & $\begin{array}{l}\text { Brazilian Household } \\
\text { Sample Survey (PNAD), } \\
\text { IBGE, 1981-1999. }\end{array}$ & $\begin{array}{l}\text { Trying to respond to how gender composition of jobs influence gender wage gaps, the study aims to measure (i) the } \\
\text { occupational sex segregation of nonagricultural labor force during } 1981-1999 \text { in Brazil; (ii) occupational sex segregation by } \\
\text { marital status, and (iii) occupational sex segregation by groups of hours of work and labor market segmentation. } \\
\text { In spite of the increasing female proportion in Brazilian labor force, from } 33.4 \% \text { in } 1981 \text { to } 41.7 \% \text { in 1999, men and women } \\
\text { are still both concentrated in the occupations with predominance of its respective sex. Despite the sharp rise in women's } \\
\text { labor force participation and their higher representation in integrated occupations, the gender gap in earnings narrowed } \\
\text { only slightly during the two last decades. Results show, a positive role played by marital status in occupational segregation } \\
\text { by sex. In addition, results show that compositional effects are very significant; that is, gender composition effects do not } \\
\text { operate in isolation of the other structural changes. The gender gap increases with the increase of the female proportion and } \\
\text { a divergent trend of men's and women's adjusted curves suggests that the gender wage gap is actually increasing. }\end{array}$ & $\begin{array}{l}\text { Size-standardized } \\
\text { dissimilarity index }\end{array}$ \\
\hline $\begin{array}{l}\text { Arias, Yamada } \\
\text { and Tejerina } \\
(2002)\end{array}$ & & $\begin{array}{l}\text { Study reviews the linkages between races, family background and education and wage gaps between whites and afro } \\
\text { descendant population in Brazil. Results showed that differences in human capital, including parental education and } \\
\text { education quality, and in its returns, account for most but not all of the earnings gap; } 10 \% \text { remains unexplained. }\end{array}$ & Mincer equations \\
\hline
\end{tabular}




\begin{tabular}{|c|c|c|c|}
\hline & & $\begin{array}{l}\text { As a key finding, the studied showed the important role play by gradient of skin color, labor market performance, } \\
\text { particularly in earnings. }\end{array}$ & \\
\hline $\begin{array}{l}\text { Arabsheibani, } \\
\text { Carneiro and } \\
\text { Henley } \\
\text { (2003) }\end{array}$ & PNAD 1988-1998 & Gender wage gap decreases over time but with an increasing unexplained component. & $\begin{array}{l}\text { Juhn, Murphy and } \\
\text { Pierce's (1993) version of } \\
\text { OB decomposition }\end{array}$ \\
\hline $\begin{array}{l}\text { Loureiro, } \\
\text { Carneiro and } \\
\text { Sachsida } \\
(2004)\end{array}$ & PNAD 1992, 1998 & Gender wage gaps are greater in urban areas than in rural ones. The unexplained component follows the same pattern. & $\begin{array}{l}\text { OB decomposition with } \\
\text { correction for selection } \\
\text { bias (participation in the } \\
\text { labor market) }\end{array}$ \\
\hline $\begin{array}{l}\text { Arcand and } \\
\text { D'Hombres } \\
(2004)\end{array}$ & PNAD 1998 & $\begin{array}{l}\text { Ethnic wage and employment gaps, as well as occupational segregation in Brazil, using the Oaxaca decomposition } \\
\text { methodology. The most striking result is that the impact of occupational segregation is negligible. Therefore, programs } \\
\text { aimed at facilitating the access of Afro-Brazilians to sectors where they are underrepresented do not appear as a legitimate } \\
\text { course of action in the Brazilian case. However, a portion of the discrimination and of endowment effects estimated here are } \\
\text { potentially due to unequal opportunities in an individual's capacity to finance a private education. }\end{array}$ & $\begin{array}{l}\text { Extension of Oaxaca } \\
\text { methodology }\end{array}$ \\
\hline $\begin{array}{l}\text { Salas and } \\
\text { Leite (2007) }\end{array}$ & $\begin{array}{l}\text { (PNAD) /Brasil, y } \\
\text { (ENE)/ México. }\end{array}$ & $\begin{array}{l}\text { Analyzes changes in gender occupational segregation patterns in Brazil and Mexico in } 1995 \text { and } 2004 \text {. } \\
\text { Given higher levels of education and increase of out-of-home activities among women, wage differentials tend to be highly } \\
\text { caused by sectoral and occupational segregation. Results show that in both countries there has been an increase in the level } \\
\text { of female labor force participation, decrease in wage gaps, and increase of women's participation in traditionally-male } \\
\text { occupations. However, the study showed that Brazil had a more pronounced decrease in the level of occupational } \\
\text { segregation when compared to Mexico. }\end{array}$ & $\begin{array}{l}\text { Karmel-MacLachlan } \\
\text { Index }\end{array}$ \\
\hline $\begin{array}{l}\text { Scorzafave } \\
\text { and Pazello } \\
(2007)\end{array}$ & PNAD 1988;1996;2004 & $\begin{array}{l}\text { Aims to resolve the identification problem in the Oaxaca-Blinder decomposition. Results show that gender wage gap } \\
\text { narrowed in Brazil, from } 0.475 \text { in } 1988 \text { to } 0.216 \text { in } 2004 \text {. In other words, in } 1988 \text {, men earned } 47.5 \% \text { higher wages than } \\
\text { women, but in } 2004 \text { this difference had fallen to } 21.6 \% \text {. Study highlights the importance of the part-time variable in the } \\
\text { decline in the gender wage gap in Brazil over the past } 20 \text { years. }\end{array}$ & $\begin{array}{l}\text { Oaxaca and } \\
\text { Ramson; Yun } \\
\text { Decomposition }\end{array}$ \\
\hline \multirow[t]{2}{*}{ King (2007) } & PNAD 1989 and 2001 & $\begin{array}{l}\text { Reviews occupational segregation in Brazil. Literature review and data analysis showed more pronounced levels of gender } \\
\text { segregation in the informal than in the formal sector, and in the formal labor market than in the public sector. } \\
\text { Furthermore, King argues occupational segregation plays an important role in earnings differentials especially between } \\
\text { males and females. Education attainment may also determine wage earnings, though with different impacts in the gender } \\
\text { and ethnic gaps. Ethnic segregation decreases with higher education, while it increases for women. }\end{array}$ & Duncan index \\
\hline & & Racial and Gender Gaps & \\
\hline Silva (1980) & Census 1960 & For racial wage gaps, explained component dominates. Black and brown people show similar patterns. & OB decomposition \\
\hline $\begin{array}{l}\text { Camargo and } \\
\text { Serrano } \\
(1983)\end{array}$ & $\begin{array}{l}\text { Anuario do Trabalho } \\
1976\end{array}$ & $\begin{array}{l}\text { Differences are mostly linked to personal characteristics such as levels of education, but more so to characteristics of the } \\
\text { labor market such as the structure of the firms' sector. The explained component seems to be wider in the formal sector, } \\
\text { while in the informal; differences in human capital endowments can explain most of the differential. }\end{array}$ & Chow Test \\
\hline Lovell (1994) & Census 1960, 1980 & Before 1980 , gender gaps were greater than racial gaps. & $\begin{array}{l}\text { Modified version of OB } \\
\text { decomposition as } \\
\text { proposed by Jones and } \\
\text { Kelly (1984) }\end{array}$ \\
\hline
\end{tabular}




\begin{tabular}{|c|c|c|c|}
\hline $\begin{array}{l}\text { Lovell and } \\
\text { Wood (1998) }\end{array}$ & Census 1960, 1980 & Over time the unexplained component of the wage gap differential increase while the explained component decreases. & $\begin{array}{l}\text { Modified version of OB } \\
\text { decomposition as } \\
\text { proposed by Jones and } \\
\text { Kelly (1984) }\end{array}$ \\
\hline Lovell (2000) & Census 1960; 1991 & $\begin{array}{l}\text { Review of the relationship between regional development disparities and racial and gender wage differentials. Results } \\
\text { showed significant gender and race gaps in education attainment levels and the persistence of wage gaps despite } \\
\text { improvements in education. }\end{array}$ & $\begin{array}{l}\text { Modified version of OB } \\
\text { decomposition as } \\
\text { proposed by Jones and } \\
\text { Kelly (1984) }\end{array}$ \\
\hline Soares (2000) & PNAD 1987-1998 & $\begin{array}{l}\text { The racial gap has been consistently higher and remained constant in comparison to a smaller and decreasing gender wage } \\
\text { gap. The explained component of the gap (human capital endowments) seem to explain most of the ethnic/race } \\
\text { differentials, while for the case of gender wage gaps, the unexplained component is constantly greater. }\end{array}$ & OB decomposition \\
\hline $\begin{array}{l}\text { Arias, Yamada } \\
\text { and Tejerina } \\
(2004)\end{array}$ & PNAD 1994 & $\begin{array}{l}\text { Brown people at the bottom of the earning distribution are similar to black individuals, while browns at the top are similar to } \\
\text { whites. }\end{array}$ & $\begin{array}{l}\text { OB decomposition with } \\
\text { quantile regression } \\
\text { (Koenker and Bassett, } \\
\text { 1978) }\end{array}$ \\
\hline $\begin{array}{l}\text { Arcand and } \\
\text { D'Hombres } \\
(2004)\end{array}$ & PNAD 1998 & $\begin{array}{l}\text { Unexplained component is greater in the case of black people than brown individuals. The impact of occupational } \\
\text { segregation is negligible. }\end{array}$ & $\begin{array}{l}\text { OB decomposition with } \\
\text { quantile regression } \\
\text { (Koenker and Bassett, } \\
\text { 1978) and correction for } \\
\text { selection bias for } \\
\text { occupational attachment } \\
\text { (Brown et al,. 1980) }\end{array}$ \\
\hline Lovell (2006) & $\begin{array}{l}\text { Census 1960, 1980, } \\
1991 \text { and 2000: }\end{array}$ & $\begin{array}{l}\text { Examines trends in racial and gender wage disparities in urban Sao Paulo. Despite improvements in terms of education and } \\
\text { increased access to higher-paying jobs, ethnic minorities (Afro Brazilians) and women continued to receive lower salaries } \\
\text { than their white male peers. Differences in human capital endowments explain only a small part of wage gaps and identified } \\
\text { an increasing trend in the unexplained component of the gap over time. }\end{array}$ & $\begin{array}{l}\text { Modified version of OB } \\
\text { decomposition as } \\
\text { proposed by Jones and } \\
\text { Kelly (1984) }\end{array}$ \\
\hline $\begin{array}{l}\text { Carvalho, Neri } \\
\text { and Silva } \\
(2006)\end{array}$ & PNAD 2003 & After controlling for selectivity bias, the unexplained component shrinks. & $\begin{array}{l}\text { OB decomposition with } \\
\text { correction for selection } \\
\text { bias (participation in the } \\
\text { labor market) }\end{array}$ \\
\hline
\end{tabular}




\begin{tabular}{|c|c|c|c|}
\hline Chile & & \multicolumn{2}{|l|}{ Gender Gaps: structural characteristics of the labor market or built-in society stereotypes? } \\
\hline $\begin{array}{l}\text { Paredes } \\
(1982) \\
\text { Paredes and } \\
\text { Riveros (1994) }\end{array}$ & $\begin{array}{c}\text { Employment and } \\
\text { Unemployment Survey } \\
\text { of the University of } \\
\text { Chile }(69 ; 81)\end{array}$ & $\begin{array}{l}\text { Higher returns to education for females than for men, partly explained by higher levels of schooling. Between } 1969 \text { and } 1981 \\
\text { results showed a decrease in "discrimination" against women in the labor market. }\end{array}$ & $\begin{array}{l}\text { Blinder-Oaxaca; Shapiro- } \\
\text { Stelcner }\end{array}$ \\
\hline $\begin{array}{c}\text { Montenegro } \\
\text { and Paredes } \\
(1999)\end{array}$ & $\begin{array}{c}\text { Household Surveys, } \\
\text { University of Chile } \\
\text { 1960; } 1998 \\
\end{array}$ & $\begin{array}{l}\text { Systematic differences in returns to education and experience by gender along conditional wage condition. Returns to } \\
\text { education seemed higher for women than for men in lower quintiles. Schooling returns for women seem to be more pro- } \\
\text { cyclical than men's when estimated at the mean, and the correlation between returns increase the lower the decile. Total } \\
\text { wage gap has been falling, but not due to a reduction in "discrimination." The unexplained wage gap increased over the last } \\
\text { seven years. As Chile has had a very tight labor market since the early } 1990 \text { s, with wages growing over 5\% and low } \\
\text { unemployment, discrimination is particularly expensive. }\end{array}$ & $\begin{array}{l}\text { Mincerian equations; } \\
\text { quantile regressions; } \\
\text { Oaxaca Decomposition }\end{array}$ \\
\hline \multirow{2}{*}{$\begin{array}{l}\text { Montenegro } \\
\text { (2001) }\end{array}$} & \multirow{2}{*}{$\begin{array}{c}\text { National } \\
\text { Characterization Socio- } \\
\text { economic (CASEN) } \\
\text { surveys } \\
(90 ; 92 ; 94 ; 96 ; 98)\end{array}$} & \multirow{2}{*}{$\begin{array}{l}\text { Systematic differences in the returns to education and experience between men and women could to some extent explain } \\
\text { wage differentials. Men and women's private returns to education tend to increase as we move from the lower to the upper } \\
\text { part of the conditional wage distribution. The unexplained wage gap steadily increases from } 10 \text { to } 40 \% \text { as we move from the } \\
\text { lower part to the upper part of the conditional wage distribution. }\end{array}$} & Mincerian equations; OLS \\
\hline & & & Oaxaca-decomposition \\
\hline Selamé (2004) & CASEN 2000 & $\begin{array}{l}\text { Reviews links between gender, poverty and employment. Results show that } 98.5 \% \text { of income in women-headed households } \\
\text { comes from work or social protection benefits. Also, as a sign of occupational segregation, women are over-represented in } \\
\text { low-paid jobs, receiving on average } 49.5 \% \text { of men's salaries. Socio-economic standing of a household has a direct effect on } \\
\text { women's labor participation and its level of dependency to house-related responsibilities. } \\
\text { Women in Chile face exclusion before entering and in the labor market. Women face unequal conditions of access to labor } \\
\text { market due to social norms that define a large portion of women's responsibilities as unpaid (and therefore, unrecognized). }\end{array}$ & Lit review \\
\hline $\begin{array}{l}\text { Contreras and } \\
\text { Plaza (2004) }\end{array}$ & $\begin{array}{l}\text { Survey "Mujer y } \\
\text { Trabajo, Familia y } \\
\text { Valores". } 2005\end{array}$ & $\begin{array}{l}\text { Analysis of the impact of male chauvinism and values on female labor force participation rates in Chile. } \\
\text { Traditional "societal norms" would seem to diminish more than double the positive effects of human capital variables: } \\
\text { human capital variables increase by } 9 \% \text { the probability of a woman to enter the labor force, while cultural factor decreases } \\
\text { her chances by } 23 \% \text {. }\end{array}$ & Regression models \\
\hline $\begin{array}{l}\text { Fuentes, } \\
\text { Palma and } \\
\text { Montero } \\
(2005)\end{array}$ & $\begin{array}{l}2000 \text { and } 2003 \text { CASEN } \\
\text { surveys. }\end{array}$ & $\begin{array}{l}\text { Study quantifies the evolution of wage differentials among men and women overtime: wage discrimination has decreased } \\
\text { overtime, but remains positive, whereas women are } 14.3 \% \text { underpaid and men are } 13.2 \% \text { overpaid. }\end{array}$ & $\begin{array}{l}\text { Oaxaca-Blinder; Oaxaca- } \\
\text { Ransom }\end{array}$ \\
\hline Acosta (2007) & CASEN 2006 & $\begin{array}{l}\text { Female labor force participation in Chile has increased in the } 1990-2000 \text { periods, and there has been a reduction in the level } \\
\text { of the aggregate gender wage gap. In addition, there has been an increase in the level of unemployment and } \\
\text { underemployment among women, coupled with their overrepresentation in the informal sector. Women continue to face } \\
\text { structural barriers when trying to access certain types of occupations and decision-making posts. }\end{array}$ & Lit. Review \\
\hline $\begin{array}{l}\text { Benvin and } \\
\text { Perticara } \\
\text { (2007) }\end{array}$ & $\begin{array}{c}\text { CASEN } \\
(1990 ; 1996 ; 2003)\end{array}$ & $\begin{array}{l}\text { Increase in education levels among women is one of the main determinants of increase in labor force participation rate. } \\
\text { Changes in fertility have no impact on participation rates. Although education and the number of children in a household } \\
\text { play an important role in women's decision to enter the labor force, the greatest part of the change cannot be explained by } \\
\text { these variables, but by structural changes over time in the labor market or economic context. }\end{array}$ & Yun (2004) decomposition \\
\hline
\end{tabular}




\begin{tabular}{|c|c|c|c|}
\hline $\begin{array}{l}\text { Bravo, } \\
\text { Sanhueza and } \\
\text { Urzua (2008a) }\end{array}$ & $\begin{array}{l}\text { raw data collected for } \\
\text { study }\end{array}$ & $\begin{array}{l}\text { Review of differences in wages between different occupations in Chile, as well as the extent to which schooling and family } \\
\text { background may influence labor market outcomes. Study: distribution of fictitious CVs to analyze differences in call response } \\
\text { rates. Levels of schooling can explain several differences in the labor market. Men and women have same probability of } \\
\text { being called for an interview. In the upper class group, women registered a slightly higher response than men. }\end{array}$ & $\begin{array}{l}\text { experimental study/field } \\
\text { work }\end{array}$ \\
\hline $\begin{array}{l}\text { Bravo, } \\
\text { Sanhueza and } \\
\text { Urzua (2008b) }\end{array}$ & $\begin{array}{l}\text { raw data collected for } \\
\text { study }\end{array}$ & $\begin{array}{l}\text { Review of gender differences in professional labor markets: Business, Law and Medicine. Gender wage gaps only found in } \\
\text { the legal profession. Other important variables explaining differences are the level of responsibility in the job, having } \\
\text { postgraduate studies, size of firm and regional effect. }\end{array}$ & Ordered probit model. \\
\hline \multirow{2}{*}{$\begin{array}{l}\text { Astudillo and } \\
\text { Perticará } \\
\text { (2008) }\end{array}$} & \multirow[b]{2}{*}{$\begin{array}{l}\text { Social Protection } \\
\text { Survey }(2002-06)\end{array}$} & \multirow{2}{*}{$\begin{array}{l}\text { Education becomes significant to explain gaps only after the 50th percentile and there is favorable to women. The } \\
\text { unexplainable gap is larger at the median of the distribution curve of salaries, especially among service sector and skilled } \\
\text { agricultural workers. Gaps seem to decrease at both ends of the wage distribution spectrum. }\end{array}$} & Quintile regression model \\
\hline & & & $\begin{array}{l}\text { Melly (2006) } \\
\text { decomposition } \\
\end{array}$ \\
\hline \multicolumn{2}{|c|}{$\begin{array}{l}\text { Central America: Costa Rica, Honduras } \\
\text { and Panama }\end{array}$} & Gender Gaps: Regional disparities & \\
\hline $\begin{array}{l}\text { Gindling (1991; } \\
\text { 1992) }\end{array}$ & $\begin{array}{l}\text { Household survey of } \\
\text { employment and } \\
\text { unemployment (1989) }\end{array}$ & $\begin{array}{l}\text { Costa Rica: analysis show women being over-represented in public high-paying jobs, but also in lowest-paying domestic } \\
\text { sector. }\end{array}$ & $\begin{array}{l}\text { Brown, Moon and Zoloth } \\
\text { (1980) }\end{array}$ \\
\hline Yang (1992) & $\begin{array}{l}\text { Encuesta de Hogares } \\
\text { de Propósitos Multiples } \\
\text { (EHPM) } 1989\end{array}$ & $\begin{array}{l}\text { Wage differences are relatively low (19\%). This difference may be attributed to differentials in rewards to experience, as } \\
\text { women show higher returns to investment in schooling than men. However, differentials seem to be explained by } \\
\text { unobserved characteristics. }\end{array}$ & $\begin{array}{l}\text { Mincer; Oaxaca } \\
\text { decompositions }\end{array}$ \\
\hline Arends (1992) & $\begin{array}{l}\text { Encuesta de Hogares- } \\
\text { Mano de Obra (1989) }\end{array}$ & $\begin{array}{l}\text { Panama: clear difference between women's earnings in the Canal Zone and Panama City and other areas such as Darien, } \\
\text { Veragua and Coclé. Wage decomposition results show that at least } 85 \% \text { of the wage differential cannot be explained by } \\
\text { differences in human capital, and thus need to be further examined. }\end{array}$ & $\begin{array}{l}\text { Oaxaca-Blinder } \\
\text { Decomposition }\end{array}$ \\
\hline $\begin{array}{c}\text { Funkhouser } \\
(1997)\end{array}$ & $\begin{array}{l}1991 / 92 \text { National } \\
\text { Household Survey }\end{array}$ & $\begin{array}{l}\text { El Salvador review of formal and informal employment in urban areas. Author evaluates movements of individual male and } \\
\text { female workers within and between formal and informal employment from } 1991 \text { to } 1992 \text { and analyze impacts on changes in } \\
\text { wages. Female workers who moved from the informal sectors and the formal sector had nominal wages increases two to } \\
\text { three times those of workers who changed jobs within the same sector of employment. Female workers who moved from } \\
\text { the formal sector to the informal sector suffered nominal wage losses. There is little difference in the earnings } \\
\text { characteristics of those who stay in the same informal sector job compared to other workers who were employed in the } \\
\text { informal sector }\end{array}$ & OLS regressions \\
\hline $\begin{array}{c}\text { Dávila and } \\
\text { Pagán (1999) }\end{array}$ & $\begin{array}{l}\text { Encuesta de hogares } \\
\text { para propósitos } \\
\text { multiples- CR-1989/ } \\
\text { Household Survey-ES- } \\
\quad 1989 .\end{array}$ & $\begin{array}{l}\text { El Salvador and Costa Rica review of gender occupational attainment and gender differentials, comparing their different } \\
\text { economic recovery paths and labor reforms. Earnings differential between men and women was larger in Costa Rica than in } \\
\text { El Salvador during the late 1980s. This gender earnings gap, however, is due partly to the fact that women in El Salvador } \\
\text { worked more hours than Costa Rican women: net of inter-country differences in occupational attainment and hours of } \\
\text { work, the gender earning gaps between the two countries was not very large. }\end{array}$ & Mincer equations \\
\hline $\begin{array}{l}\text { Tenjo, Medina } \\
\text { and Bernat } \\
\text { (2004) }\end{array}$ & Household surveys & $\begin{array}{l}\text { In Costa Rica and Honduras, returns to education are always greater for women than for men; however, Costa Rica seemed } \\
\text { to be the only country with no clear tendency towards wage equalization. }\end{array}$ & Oaxaca decomposition \\
\hline
\end{tabular}




\begin{tabular}{|c|c|c|c|}
\hline Monroy (2008) & EMNV 2005. & $\begin{array}{l}\text { Nicaragua's survey on labor market. Analysis found that the gender wage gap is around } 19.8 \% \text {, where the smaller gap is } \\
\text { found among unskilled workers and the largest among agricultural and fishing activities. Ethnic wage gap is around } 27.8 \% \text {. } \\
\text { Occupational segregation seems to decrease as educational levels increase, and among the younger segments of the } \\
\text { population. }\end{array}$ & Duncan Index \\
\hline Colombia & & Gender Gaps: Is high labor participation enough and the Glass ceiling effect & \\
\hline Tenjo (1992) & $\begin{array}{l}\text { Household sample- } \\
\text { DANE } 1979\end{array}$ & $\begin{array}{l}\text { In this study, Tenjo finds that a large part of the wage differential was attributed to the inclusion or exclusion of domestic } \\
\text { servants; Colombian women have higher levels of education than men, and on average receive higher percentage premiums } \\
\text { than men in the same occupation }\end{array}$ & Heckman; Gunderson \\
\hline $\begin{array}{l}\text { Vélez and } \\
\text { Winter (1992) }\end{array}$ & $\begin{array}{c}1988 \text { National } \\
\text { Household Survey }\end{array}$ & $\begin{array}{l}\text { Strong positive links between education and female labor force participation, but at the same time a significant percentage } \\
\text { of women working in low wage informal jobs. }\end{array}$ & $\begin{array}{l}\text { Earnings functions; Oaxaca } \\
\text { decomposition }\end{array}$ \\
\hline $\begin{array}{l}\text { Urdinola and } \\
\text { Wodon (2006) }\end{array}$ & $\begin{array}{l}\text { Encuesta Nacional de } \\
\text { Hogares (1982-2000) }\end{array}$ & $\begin{array}{l}\text { Review of trends in labor force participation and wage differentials and their potential links with Pregnancy Laws and } \\
\text { poverty. Their examination on the impact on poverty of the increase in gender gaps showed that where the gender gap } \\
\text { increased in the country, so did relative poverty, as poor households were more vulnerable to the decrease in relative } \\
\text { wages among unskilled wages. Review trends of ratio male-female wages: long-term trend towards increase in gender wage } \\
\text { gap related to labor regulations (more protection given to women, raising costs of female employment for firms). Link } \\
\text { between poverty and gender wage gap: as the gender wage gap increased, so did relative poverty, as the decrease in } \\
\text { relative wages among unskilled females hit poor households the most. }\end{array}$ & Standard wage regressions \\
\hline $\begin{array}{l}\text { Bernat and } \\
\text { Vélez Robayo } \\
\text { (2008) }\end{array}$ & $\begin{array}{l}\text { Encuesta Hogares de } \\
\text { áreas metropolitana - } \\
2006 \text { and CNO-88 }\end{array}$ & $\begin{array}{l}\text { Relationship between occupational segregation and the wage differences between men and women in Cali, Colombia. } \\
\text { Results show that women in traditionally-male occupations tend to earn higher wages than men, have on average, almost } \\
\text { two more years of education, and have lower returns to women in traditionally female occupations. } \\
\text { Occupational segregation seems to be a statistically significant component to explain gender wage gaps in Cali. }\end{array}$ & $\begin{array}{c}\text { Flückiger \& Silber (1999) } \\
\text { decomposition }\end{array}$ \\
\hline $\begin{array}{l}\text { Badel and Peña } \\
\text { (2009) }\end{array}$ & $\begin{array}{l}\text { Colombian Household } \\
\text { Survey } 2006\end{array}$ & $\begin{array}{l}\text { Despite increased female labor force participation, working hours and scope of women in labor force, women earn lower } \\
\text { wages than men. Gap explained by differences in rewards to labor market characteristics (age and schooling). The patterns } \\
\text { of women's wages seem to suggest a glass ceiling effect, where women face barriers to advancement once they reach a } \\
\text { certain level or position. }\end{array}$ & $\begin{array}{l}\text { Quantile Regression } \\
\text { Framework } \\
\text { Machado-Mata } \\
\text { Decomposition }\end{array}$ \\
\hline $\begin{array}{l}\text { Tomal and } \\
\text { Johnson (2008) }\end{array}$ & $\begin{array}{l}\text { Survey made specific } \\
\text { for study }\end{array}$ & $\begin{array}{l}\text { Specific survey to measure the gender earnings gap for self-employed women and men, and to identify earnings } \\
\text { determinants based on both gender and loan source differences among the self-employed within the informal economy of } \\
\text { Bogotá. Results showed no statistically significant gender earnings gap between men and women entrepreneurs in the } \\
\text { informal economy. It also concluded that the variables that explain earnings are education attainment, household help and } \\
\text { microfinance loans (access to credit). }\end{array}$ & Mincerian earnings function \\
\hline
\end{tabular}




\begin{tabular}{|c|c|c|c|}
\hline \multicolumn{4}{|l|}{ Ecuador } \\
\hline $\begin{array}{l}\text { Larrea and } \\
\text { Montenegro } \\
\text { Torres (2006) }\end{array}$ & $\begin{array}{c}\text { Living conditions Surrey } \\
1998 \\
\end{array}$ & $\begin{array}{l}\text { Authors explore socioeconomic and ethnic determinants of earnings. The study shows that on average indigenous peoples } \\
\text { receive } 55 \% \text { of non-indigenous peoples' earnings. Results show that for men, differentials can be explained by difference in } \\
\text { education levels, and the number of women employed in the informal sector. When male and women are analyzed } \\
\text { together, } 74 \% \text { is explained by differences in human capital endowments, mainly education. }\end{array}$ & Oaxaca-Blinder \\
\hline $\begin{array}{l}\text { García-Aracil } \\
\text { and Winter } \\
(2005)\end{array}$ & 1999 Household Survey & $\begin{array}{l}\text { Reviews relationship between low educational attainments and earnings. Review showed small gender differences in } \\
\text { educational attainment, while larger between indigenous males and females. Results indicate that much of the ethnic wage } \\
\text { differentials could be explained by higher years of schooling and urban residence. }\end{array}$ & $\begin{array}{c}\text { Proportional Hazard Model; } \\
\text { Oaxaca and Ranson }\end{array}$ \\
\hline Guatemala & & \multicolumn{2}{|l|}{ Ethnic gaps: How to deal with ethnic wage gaps in ethnically diverse countries? } \\
\hline Patrinos (1997) & $\begin{array}{l}1989 \text { household survey/ } \\
\text { Encuesta Nacional } \\
\text { Socio-demográfica } \\
\text { (ENSD) }\end{array}$ & $\begin{array}{l}\text { Results show clear differences in levels of schooling between ladinos and indigenous individuals, and also differences within } \\
\text { ethnicities: the Quiché receive lower returns, while the Mam receive very high returns. Furthermore, the unexplained } \\
\text { component of the earnings gap, also varies between groups whereas within the Kakchiquel and Mam this component is far } \\
\text { lower than within the Quiché and other. This clearly calls for specific targeted policy interventions. }\end{array}$ & $\begin{array}{c}\text { Oaxaca-Ransom; Oaxaca } \\
\text { decomposition }\end{array}$ \\
\hline Sauma (2004) & ENCOVI 2000 survey & $\begin{array}{l}\text { Despite having the larger labor force in Central America by } 2000 \text { (around } 4.5 \text { million), the country reached low levels of } \\
\text { productivity due to low educational levels of its workforce. In terms of wages, indigenous women have the lowest wages, } \\
\text { followed by indigenous men who earn even less then non-indigenous women. }\end{array}$ & \\
\hline Pagán (2002) & $\begin{array}{l}1997 \text { Survey of Rural } \\
\text { Entrepreneurs }\end{array}$ & $\begin{array}{l}\text { Male-female differences in female labor force participation in rural areas (San Marcos, Quezaltenango, Huehuetenango, Alta } \\
\text { Verapaz, Petén and Chimiquimula). Female workforce participation in rural Guatemala is much lower than that of men. } \\
\text { Women are over-represented in self-employment sector. }\end{array}$ & $\begin{array}{l}\text { Even and Macpherson } \\
\text { (1990) probit decomposition }\end{array}$ \\
\hline Alejos (2003) & $\begin{array}{l}\text { National Survey of } \\
\text { Employment and } \\
\text { Income (ENEI) } 2002\end{array}$ & $\begin{array}{l}\text { Dual labor market. Acknowledging the existence of significant wage gaps between males and females, indigenous and non- } \\
\text { indigenous individuals, urban and rural workers, the analysis showed education as playing a key role in income inequality, } \\
\text { explaining almost } 94 \% \text { of the differentials. }\end{array}$ & Fields decomposition \\
\hline Shapiro (2006) & ENCOVI 2000 & $\begin{array}{l}\text { In an overall assessment of indigenous peoples in Ecuador, the author's analysis of earnings showed a significant ethnic } \\
\text { wage gap. Moreover, decomposition results indicated that around } 71-83 \% \text { of the wage differential could be explained by } \\
\text { differences in human capital endowments. The remainder is attributed to other elements including quality of education, } \\
\text { years of unemployment and "discrimination." }\end{array}$ & $\begin{array}{c}\text { OLS regressions } \\
\text { Cotton and Oaxaca-Ransom }\end{array}$ \\
\hline Fazio (2007) & $\begin{array}{c}\text { ENCOVI 2000; Censo } \\
\text { Nacional de Población y } \\
\text { Habitación 2002; } \\
\text { Encuesta Nacional de } \\
\text { Empleo e Ingresos } 2004\end{array}$ & $\begin{array}{l}\text { Assessment of the role of social networks on possibilities of finding a job, and on economic decisions: indigenous peoples are } \\
7 \% \text { more likely to find a job using social contacts than non-indigenous ( } 14 \% \text { in rural areas). However, in urban areas, } \\
\text { indigenous peoples are more likely to find jobs through formal channels. }\end{array}$ & Bertrand et al. (2000) \\
\hline
\end{tabular}




\begin{tabular}{|c|c|c|c|}
\hline \multicolumn{2}{|l|}{ Mexico } & \multicolumn{2}{|l|}{ Gender Gaps: "Sticky floor" and "Glass Ceiling" } \\
\hline Steele (1992) & 1984 ENVIH & $\begin{array}{l}\text { While a large portion of the wage differential can be explained by differences in human capital, most is associated with } \\
\text { different market values placed on these female and characteristics. Looking at variables such as productive skills, personal } \\
\text { characteristics and other features such as area of residence, there is a positive influence of education on women's labor } \\
\text { force participation, and earnings, but also a large unexplained part of the wage differential. }\end{array}$ & Oaxaca Decomposition \\
\hline $\begin{array}{l}\text { Brown, Pagán } \\
\text { and Rodríguez- } \\
\text { Oreggia (1999) }\end{array}$ & $\begin{array}{l}\text { Mexico's National } \\
\text { Urban Employment } \\
\text { Survey }\end{array}$ & $\begin{array}{l}\text { Increase in gender earning gaps explained by: (i) increases in relative education levels for men; (ii) change in gender } \\
\text { differences of weekly hours worked and (iii) regional structure of wages. Despite gender wage gap increase, portion } \\
\text { attribute to male-female differences in rewards to individual endowments fell. Policies to support improvement of human } \\
\text { capital investment for women may not be effective in reducing existing wage gaps as differentials are linked to barriers of } \\
\text { access for women to high quality and stable jobs, as well as less hours of work. }\end{array}$ & $\begin{array}{l}\text { Wellington (1993) earning } \\
\text { decomposition }\end{array}$ \\
\hline & & $\begin{array}{l}\text { Gender differences are more pronounced among working individuals than among the overall population. Their analysis } \\
\text { showed an increase in female labor force participation, especially in the self-employment and non-agricultural sectors; the }\end{array}$ & $\begin{array}{c}\text { Standard employment } \\
\text { selection model }\end{array}$ \\
\hline $\begin{array}{c}\text { Pagán and } \\
\text { Sánchez (2000) }\end{array}$ & $\begin{array}{c}\text { Survey of Rural } \\
\text { Entrepreneurs and } \\
\text { Financial Services } 1994\end{array}$ & $\begin{array}{l}\text { self-employment sector provides women with the appropriate flexibility and easier access to income-generating activities. } \\
\text { Negative effect of presence of young children on women's workforce participation: women are forced to balance family and } \\
\text { market responsibilities, which becomes a major constraint on women's work, productivity and earnings. Policies aimed at } \\
\text { reducing gender inequality in rural labor market need to include both actions to increase individual human endowments, as } \\
\text { well as structural demand and supply factors }\end{array}$ & $\begin{array}{l}\text { W.E. Even and D.A. } \\
\text { MacPherson } \\
\text { decomposition }\end{array}$ \\
\hline $\begin{array}{l}\text { Pagán and } \\
\text { Ullibari (2000) }\end{array}$ & $\begin{array}{l}\text { Encuesta Nacional de } \\
\text { empleo urbano }\end{array}$ & $\begin{array}{l}\text { The unexplained portion of wage inequalities is larger for those with lower levels of education, or those with } \\
\text { college/university degrees, implying the need to explore group-specific targeted polices rather than programs for women as } \\
\text { a whole to close wage differentials. }\end{array}$ & Jenkins index \\
\hline Madrigal (2004) & $\begin{array}{l}\text { General Population } \\
\text { Census (1970; 1990; } \\
\text { 2000) }\end{array}$ & $\begin{array}{l}\text { Review links between labor force participation and fertility rates (continuation of Cruces and Galiani study). Results confirm } \\
\text { the hypothesis that higher rates of fertility may result in lower levels of female labor participation; differences in the } \\
\text { strength of this relationships depends on the level of education attained by women, Women with a higher level of schooling } \\
\text { have a higher opportunity cost while leaving their jobs, even though it might represent higher incomes for their families. This } \\
\text { may lead to think for the need to introduce flexible mechanisms inside work places to that prevent high-qualified women to } \\
\text { leave the labor market, and to allow women to maintain stable sources of income. }\end{array}$ & $\begin{array}{c}\text { Angrist and Evans (1998)/ } \\
\text { Wald estimators }\end{array}$ \\
\hline \multirow[t]{2}{*}{ Popli (2008) } & $\begin{array}{c}\text { ENIGH }(1984 ; \\
1994 ; 1996 ; 2002)\end{array}$ & $\begin{array}{l}\text { Raw wage between men and women is not significant when reviewing workers in the formal sector. However, given higher } \\
\text { levels of returns to education for women, women should on average have higher wages than men. Issues such as a } \\
\text { persistent occupational segregation, age and region of residence appear to be factoring in to explain differences. Evidence of } \\
\text { "sticky floor" and "glass ceiling" }\end{array}$ & $\begin{array}{l}\text { Blinder-Oaxaca } \\
\text { decomposition; Jenkins } \\
\text { measure; non-parametric } \\
\text { measure }\end{array}$ \\
\hline & & Ethnic Wage Gaps & \\
\hline $\begin{array}{l}\text { Chávez Castillo } \\
(2006)\end{array}$ & INEGI 2000 & $\begin{array}{l}\text { Discusses women's working as domestic employees, one of the lowest-paid occupations in the country. This is also the main } \\
\text { source of work for indigenous women, especially in Mexico's urban areas. }\end{array}$ & Literature review \\
\hline $\begin{array}{l}\text { Borja-Vega, } \\
\text { Lunde and } \\
\text { García-Moreno } \\
(2007)\end{array}$ & $\begin{array}{l}\text { INEGI 2000; ENVIH } \\
2002\end{array}$ & $\begin{array}{l}\text { Focuses on the role of social networks in indigenous peoples' labor market decisions and argues that given the lower human } \\
\text { capital endowments of indigenous peoples, they have restricted access to professional and high paid jobs. Their reliance on } \\
\text { social networks may determine specific employment outcomes. }\end{array}$ & $\begin{array}{l}\text { Shorrocks income } \\
\text { decomposition }\end{array}$ \\
\hline
\end{tabular}




\begin{tabular}{|c|c|c|c|}
\hline Ramírez (2006) & $\begin{array}{l}\text { National Income and } \\
\text { Consumption Survey } \\
2002\end{array}$ & $\begin{array}{l}\text { Given the significant income disparities between indigenous and non-indigenous peoples found in the author's analysis of } \\
\text { the Mexican economy, the author analyzed potential determinants of labor earnings and the role of ethnicity in these } \\
\text { differentials. Results show that employment type had the greatest impact on earnings, especially in indigenous areas, where } \\
\text { being an employer yields higher returns. Decomposition results showed that } 59 \% \text { of the wage gap could be explained by } \\
\text { differences in levels of productivity between indigenous and non-indigenous peoples, and among indigenous peoples, } 63- \\
68 \% \text { of the gender wage gap. The remainder could be explained by factors such as culture, quality of education, as well as } \\
\text { labor market discrimination. The very high value of this variable means that regardless of work experience, education, } \\
\text { employment category, area of residence, etc., gaps will remain. }\end{array}$ & $\begin{array}{l}\text { OLS regressions; Blinder- } \\
\text { Oaxaca }\end{array}$ \\
\hline Horbath (2007) & INEGI 2000 & $\begin{array}{l}\text { Author discusses the low levels of schooling and labor training to which indigenous peoples have access, which to a large } \\
\text { extent may define their possibilities of entry to the formal labor market. He provides an overview of indigenous workers' } \\
\text { characteristics in Mexico's main cities, the characteristics of the disparities seen in education, as well as in the labor market. } \\
\text { Pointing to the existence of a significant wage gap ranging from } 14 \% \text { to } 57 \% \text {, and limited labor mobility possibilities among } \\
\text { indigenous workers, no further analysis was developed to explain these differentials. }\end{array}$ & Duncan index \\
\hline
\end{tabular}

\begin{tabular}{|c|c|c|c|}
\hline Peru & & \multicolumn{2}{|l|}{ Gender Gaps: capital and urban primacy. Self-employment, an alternative for gender equality? } \\
\hline $\begin{array}{l}\text { Stelcner, Van } \\
\text { der Gaag and } \\
\text { Vijverberg } \\
\text { (1989) }\end{array}$ & $\begin{array}{l}\text { Peruvian Living } \\
\text { Standards Survey (1985- } \\
\text { 1986) }\end{array}$ & $\begin{array}{l}\text { The authors' objective was to identify potential relationships between wages, education, work experience and their } \\
\text { differences between sectors in Peru. In methodological terms, the authors concluded that the finding is that public-private } \\
\text { wage comparisons that are based on OLS regressions may be very misleading given inherent selectivity of the samples. The } \\
\text { authors' model shows an average wage of } 0.91 \text { in the public sector, and } 1.755 \text { in the private sector, almost a } 1 \% \text { differential } \\
\text { point. OLS regressions only gave a difference of } 0.1 \text {. }\end{array}$ & Switching Regression Model \\
\hline $\begin{array}{l}\text { Khandker } \\
\text { (1992) }\end{array}$ & $\begin{array}{l}\text { Peruvian Living } \\
\text { Standard Survey; } \\
\text { National Health and } \\
\text { Nutrition Survey (1984) }\end{array}$ & $\begin{array}{l}\text { Women have more years of schooling than men, female labor force participation is relative low, in comparison to rates in } \\
\text { the region, and wages, especially in the formal sector, are lower for women than for men. } \\
\text { Significant differences were found comparing wage structures between Lima, and other regions, giving a clear advantage to } \\
\text { women living in urban areas, despite levels of education. Improvements in education have different impacts on men and on } \\
\text { women's labor market participation, providing a strong argument against the gender neutrality of investment in education. }\end{array}$ & Oaxaca decomposition \\
\hline Gill (1992) & $\begin{array}{c}\text { 1985-86 Peruvian Living } \\
\text { Standard Survey }\end{array}$ & $\begin{array}{l}\text { Although highly educated women may be attracted by the wage sector, the lack of flexibility in such sector may lead them to } \\
\text { search for other alternatives such as self-employment. There exist clear barriers to self-employment including access to } \\
\text { credit and start-up capital. }\end{array}$ & Oaxaca decomposition \\
\hline \multirow[t]{2}{*}{$\begin{array}{l}\text { Chávez O'Brien } \\
\text { (2003) }\end{array}$} & & $\begin{array}{l}\text { Despite important improvements in women's wages in the } 1990 \text { s, they still only reach around } 60 \% \text { of men's salaries. } \\
\text { Women's participation in family and unpaid work is four times higher than men's, and although the level of unemployment } \\
\text { has decreased, women are overrepresented in low-paid jobs, which may reinforce their vulnerability to poverty. }\end{array}$ & \\
\hline & & Ethnic Wage gaps: Exclusion or "self-exclusion"? & \\
\hline $\begin{array}{l}\text { Maclsaac and } \\
\text { Patrinos (1995) }\end{array}$ & $\begin{array}{l}1991 \text { Living Standards } \\
\text { Survey. }\end{array}$ & $\begin{array}{l}\text { Indigenous workers earn significantly less than their non-indigenous peers and have only } 6.7 \text { years of schooling in } \\
\text { comparison to } 10 \text { for Spanish-speaking men; however, indigenous workers tend to have almost twice the amount of } \\
\text { experience as non-indigenous men. The larger portion of wage differential ( } 50-70 \%) \text { seems to be attributable to individuals' } \\
\text { characteristics, while the remaining part may be explained by factors such as ability, quality of education, labor force } \\
\text { attachment or culture. An increase in human capital characteristics of indigenous workers will tend to improve earnings. } \\
\text { However, the specific factors that have an effect of these differentials are precisely in the areas where indigenous peoples } \\
\text { are at the greatest disadvantage: university education, working in the public sector, and residence in Lima. }\end{array}$ & $\begin{array}{l}\text { Oaxaca-Blinder } \\
\text { decomposition; Oaxaca- } \\
\text { Ransom; Oaxaca-Cotton }\end{array}$ \\
\hline
\end{tabular}




\begin{tabular}{|c|c|l|c|}
\hline Trivelli (2005) & ENAHO 2001-IV & $\begin{array}{l}\text { Discusses linked between poverty and ethnicity. There is a significant wage gap between indigenous and non-indigenous } \\
\text { workers (49\%). Of this gap, 43\% can be explained by differences in human capital endowments. Even when indigenous } \\
\text { human capital endowments are increased, salaries are still below non-indigenous salaries. }\end{array}$ \\
\hline $\begin{array}{c}\text { Nopo, Saavedra } \\
\text { and Torero } \\
\text { (2007), }\end{array}$ & $\begin{array}{c}\text { 2000 LSMS; 2001 } \\
\text { additional module } \\
\text { (racial and ethnic } \\
\text { characteristics) }\end{array}$ & $\begin{array}{l}\text { Developed new methodology to identify earnings differentials related to observable racial and ethnic characteristics. } \\
\text { Concept to racial intensity and "score-based" methodology to identify the racial intensities among the mestizo population, } \\
\text { as well as to capture the several dimensions of ethnicity, not always included in censuses or surveys: mother tongue, } \\
\text { parental background, race, and religion. The analysis showed differentials only among wage earners and not among the self- } \\
\text { employed. Moreover, there are apparently no effects of ethnic-related variables (religion, birthplace or native tongue) over } \\
\text { earnings. The effect is positive however when human capital variables (education) are introduced. }\end{array}$ \\
\hline Barron (2008) & $\begin{array}{l}\text { Explores the impact of exclusion and discrimination on income inequality. His results showed income for average indigenous } \\
\text { workers around 44\% of non-indigenous individuals, though no difference between in terms of returns to education. The } \\
\text { analysis shows that exclusion plays a bigger role in explaining inequality and income, than discrimination. In other words, } \\
\text { indigenous individuals are excluded from certain processes that hinder their human accumulation process. In this sense, the } \\
\text { author argues, distribution in years of schooling would seem to contribute to reduce the income ethnic gap. }\end{array}$ \\
2003 ENAHO
\end{tabular}




\begin{tabular}{|c|c|c|c|}
\hline Uruguay & & \multicolumn{2}{|l|}{ Gender Gaps: At the forefront of education, still lagging in gender wage equalization } \\
\hline Arends (1992) & $\begin{array}{l}1985 \text { Encuesta } \\
\text { Nacional de Hogares } \\
\text { (DGEC) }\end{array}$ & $\begin{array}{l}\text { The wave of emigration the country experienced in the } 1970 \text { s provided an opportunity for women to enter the labor force. } \\
\text { Women's earning represented on average } 75 \% \text { of men's wages despite having higher levels of education than men. } \\
\text { Differences, however, are largely attributed to wage structures and occupational segregation, rather than to differences in } \\
\text { human capital endowments. }\end{array}$ & Oaxaca decomposition \\
\hline $\begin{array}{l}\text { Rivas and Rossi } \\
(2000)\end{array}$ & $\begin{array}{l}\text { Encuesta Continua de } \\
\text { Hogares } 1997\end{array}$ & $\begin{array}{l}\text { The gender wage gap decreased in the 1990s. Human capital and labor market insertion mainly explain changes in wage gap, } \\
\text { but the "unexplained differences" are what really explain wage differentials. }\end{array}$ & $\begin{array}{l}\text { Oaxaca-Blinder } \\
\text { Decomposition }\end{array}$ \\
\hline $\begin{array}{l}\text { Ferré and Rossi } \\
\text { (2002) }\end{array}$ & $\begin{array}{l}\text { Encuesta Continua de } \\
\text { Hogares y en } \\
\text { el Censo de Población } \\
\text { y Vivienda d }\end{array}$ & $\begin{array}{l}\text { Study aims to examine the evolution of gender occupational segregation in Uruguay 1986-1997. Authors show that the } \\
\text { highest levels of occupational segregation are seen among women in rural areas. Almost half of women would need to } \\
\text { change their occupations in order to achieve perfect integration into the labor market. }\end{array}$ & Duncan Index \\
\hline $\begin{array}{l}\text { Deutsch et al. } \\
(2004)\end{array}$ & $\begin{array}{l}\text { Household survey } \\
(89 ; 93 ; 97)\end{array}$ & $\begin{array}{l}\text { Authors found that in countries like Uruguay, were the gender gap is relatively smaller, a greater degree of occupational } \\
\text { segregation contributed to reducing the wage gap. }\end{array}$ & Flückiger and Silber (1999) \\
\hline $\begin{array}{l}\text { Tenjo, Ribero, } \\
\text { Bernat (2004) }\end{array}$ & $\begin{array}{l}\text { Household surveys } \\
\text { (LAC comparisons) }\end{array}$ & $\begin{array}{l}\text { Wage differential may be attributed to salary patterns in certain sectors, and occupational segregation. However, a strong } \\
\text { part was also attributed to traditional social structures in LAC societies preventing women from expanding labor market } \\
\text { opportunities. Wage differentials may be a result of societal characteristics and traditional roles assigned to women, } \\
\text { competing with their potential role in the labor market. }\end{array}$ & Heckman; Chow ; Oaxaca \\
\hline
\end{tabular}

